Optimization of the Area 5 Radioactive Waste Management Site Closure Cover

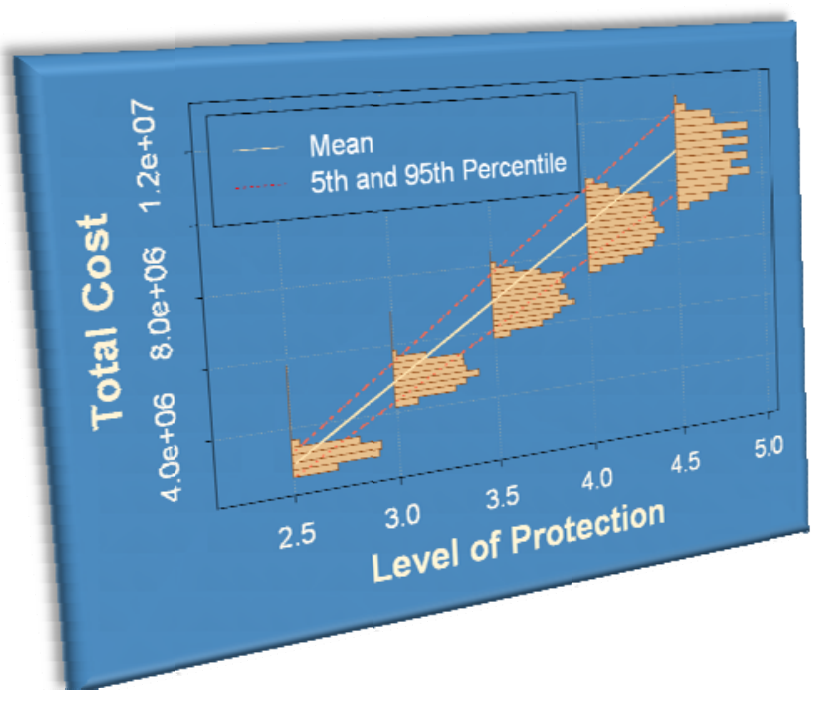

April 2009

Prepared by

Greg Shott, Vefa Yucel

National Security Technologies, LLC

Prepared for

U.S. Department of Energy

National Nuclear Security Administration Nevada Site Office

Under Contract Number DE-AC52-06NA25946 


\section{DISCLAIMER NOTICE}

Reference herein to any specific commercial product, process, or service by trade name, trade mark, manufacturer, or otherwise does not necessarily constitute or imply its endorsement, recommendation, or favoring by the United States Government or any agency thereof.

Available for sale to the public, in paper, from:

U.S. Department of Commerce

National Technical Information Service

5285 Port Royal Road

Springfield, VA 22161

Phone: (800) 553-6847

Fax: (703) 605-6900

E-mail: orders@ntis.fedworld.gov

Online Ordering: http://www.ntis.gov/ordering.htm

Available electronically at http://www.osti.gov/bridge

Available for a processing fee to the U.S. Department of Energy and its contractors, in paper, from:

U.S. Department of Energy

Office of Scientific and Technical Information

P.O. Box 62

Oak Ridge, TN 37831-0062

Phone: (865) 576-8401

Fax: (865) 576-5728

E-mail: reports@adonis.osti.gov 


\title{
Optimization of the Area 5 Radioactive Waste Management Site Closure Cover
}

\author{
April 2009
}

Prepared by

Greg Shott, Vefa Yucel

National Security Technologies, LLC

Prepared for

U.S. Department of Energy

National Nuclear Security Administration

Nevada Site Office

Under Contract Number DE-AC52-06NA25946 
This Page Intentionally Left Blank 


\section{EXECUTIVE SUMMARY}

The U.S. Department of Energy Manual DOE M 435.1-1, "Radioactive Waste Management Manual," requires that performance assessments demonstrate that releases of radionuclides to the environment are as low as reasonably achievable (ALARA). Quantitative cost benefit analysis of radiation protection options is one component of the ALARA process.

This report summarizes a quantitative cost benefit analysis of closure cover thickness for the Area 5 Radioactive Waste Management Site (RWMS) on the Nevada Test Site. The optimum cover thickness that maintains doses ALARA is shown to be the thickness with the minimum total closure cost. Total closure cost is the sum of cover construction cost and the health detriment cost. Cover construction cost is estimated based on detailed cost estimates for closure of the 92-acre Low-Level Waste Management Unit (LLWMU). The health detriment cost is calculated as the product of collective dose and a constant monetary value of health detriment in units of dollars per unit collective dose. Collective dose is the sum of all individual doses in an exposed population and has units of person-sievert (Sv).

Five discrete cover thickness options ranging from 2.5 to 4.5 meters (m) (8.2 to 15 feet [ft]) are evaluated. The optimization was subject to the constraints that (1) options must meet all applicable regulatory requirements and that (2) individual doses be a small fraction of background radiation dose.

Total closure cost is found to be a monotonically increasing function of cover thickness for the 92-ac LLWMU, the Northern Expansion Area, and the entire Area 5 RWMS. The cover construction cost is orders of magnitude greater than the health detriment cost. Two-thousand Latin hypercube sampling realizations of the relationship between total closure cost and cover thickness are generated. In every realization, the optimum cover thickness is $2.5 \mathrm{~m}(8.2 \mathrm{ft})$ for the 92-ac Low-Level Waste Management Unit, the Northern Expansion Area, and the entire Area 5 RWMS. The conclusions of the optimization are found to be insensitive to all input parameters, the monetary value of the health detriment over a range of values from $\$ 200,000$ to $\$ 15,000,000$ per person-Sv, and the period of integration of collective dose. A $2.5 \mathrm{~m}(8.2 \mathrm{ft})$ closure cover at the Area 5 RWMS can meet all applicable regulatory requirements and maintain radionuclide releases ALARA. 
This Page Intentionally Left Blank 


\section{TABLE OF CONTENTS}

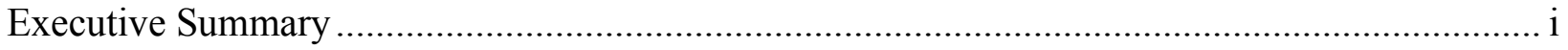

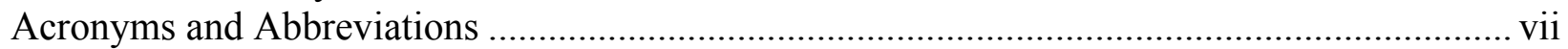

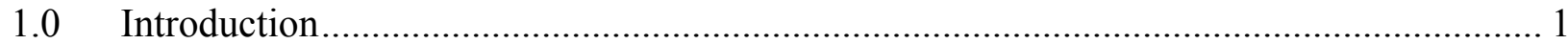

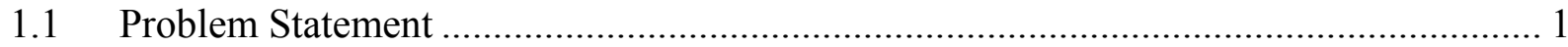

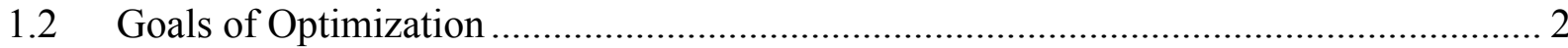

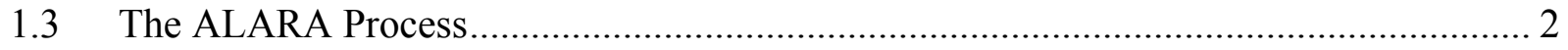

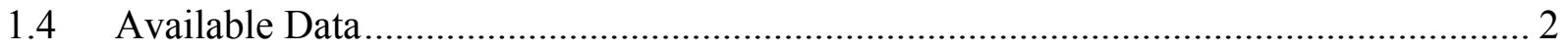

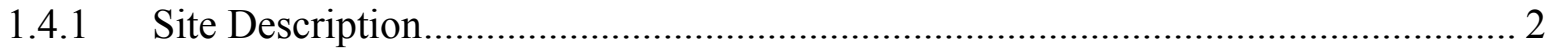

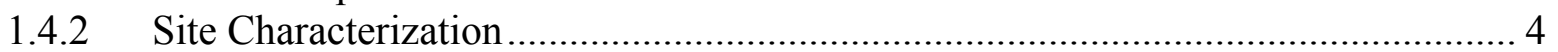

1.4.3 Previous Performance Assessment Results ...................................................... 4

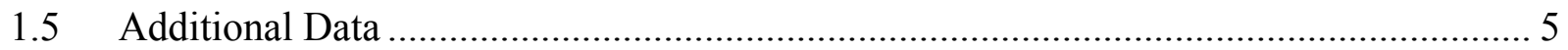

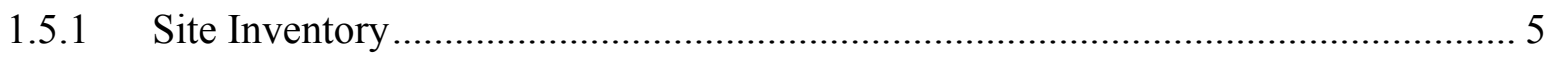

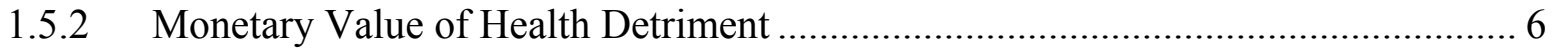

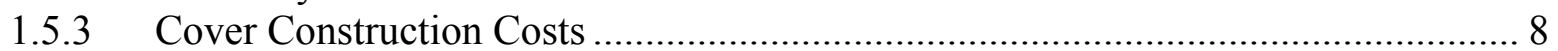

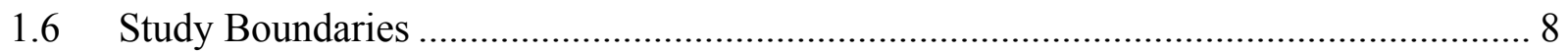

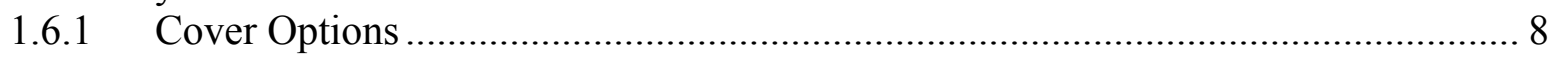

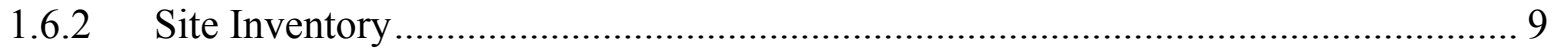

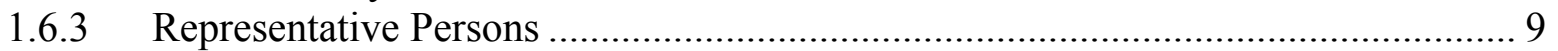

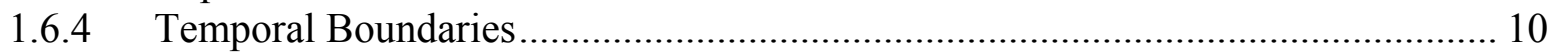

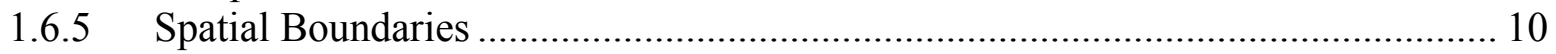

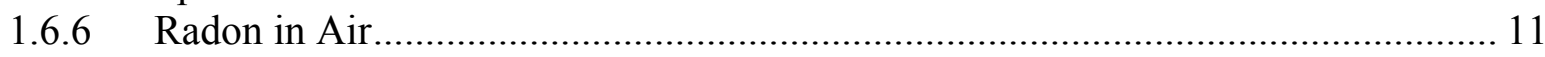

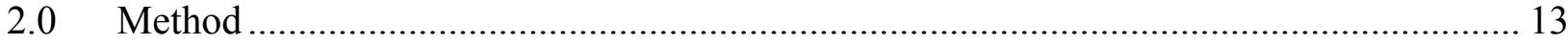

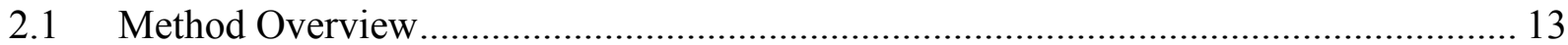

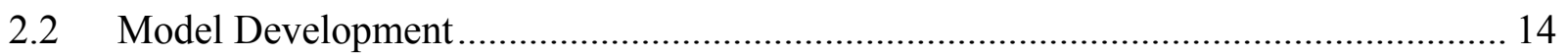

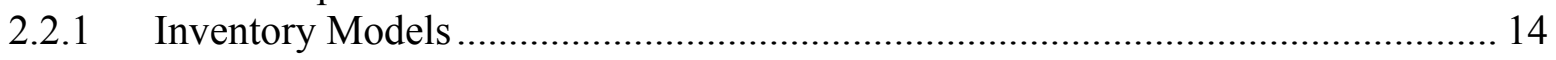

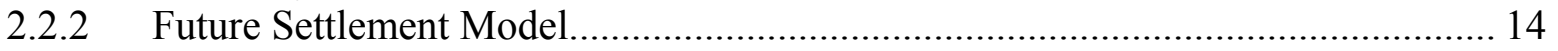

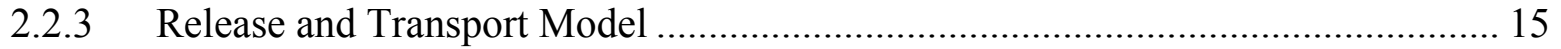

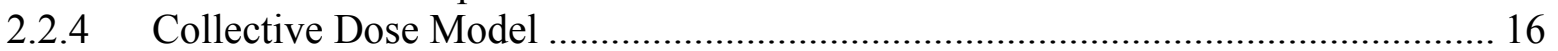

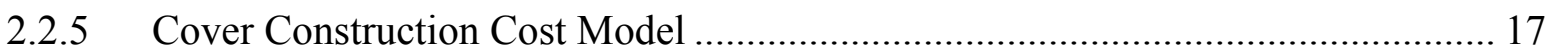

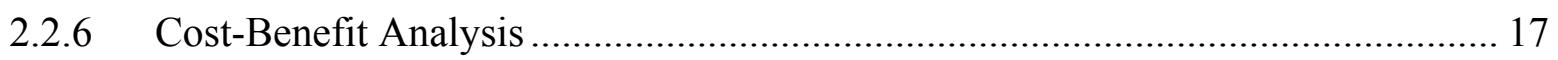

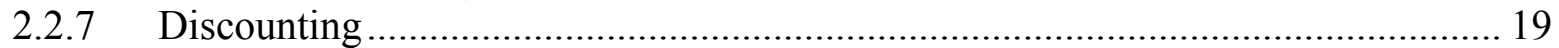

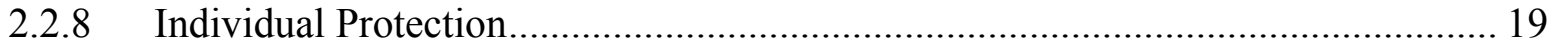

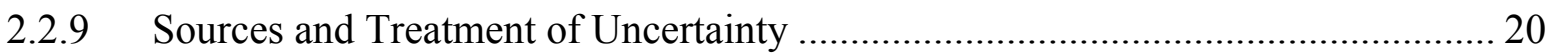

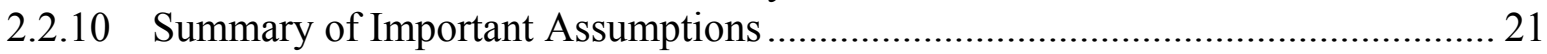

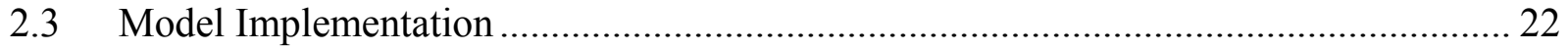

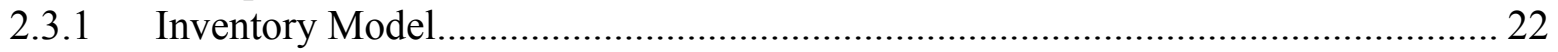

2.3.2 Settlement of Frenchman Flat ........................................................................... 22

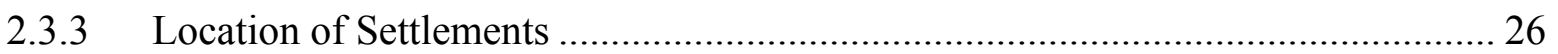

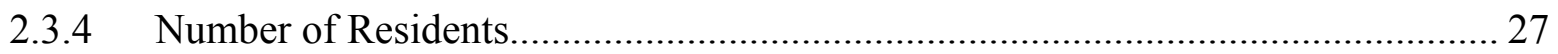

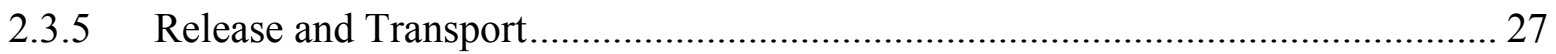

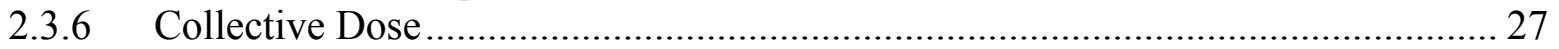

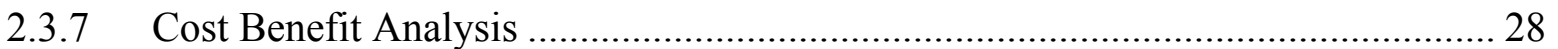

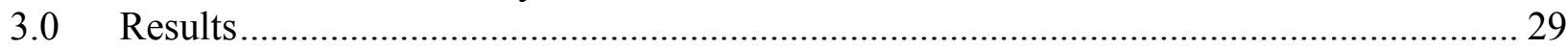

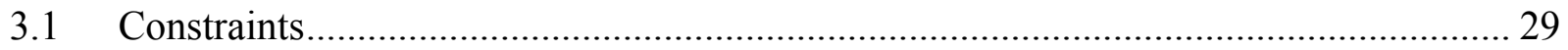


3.1.1 Compliance with Applicable Regulatory Requirements......................................... 29

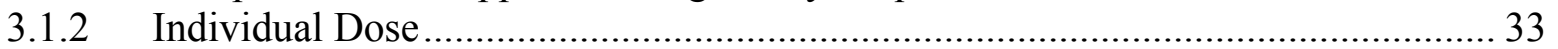

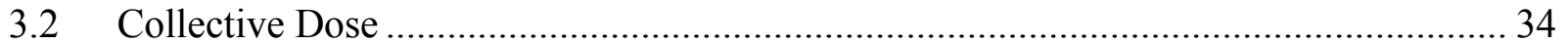

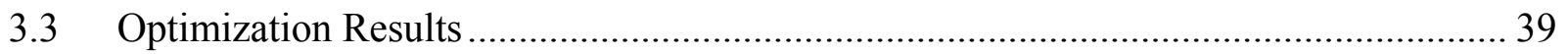

3.3.1 Optimization of the 92-ac LLWMU Closure Cover ................................................. 39

3.3.2 Optimization of the Northern Expansion Area Closure Cover ................................ 40

3.3.3 Optimization of the Area 5 RWMS Closure Cover............................................... 41

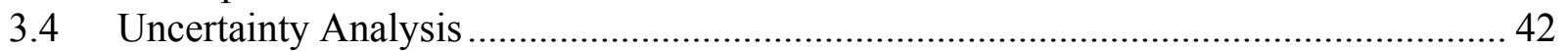

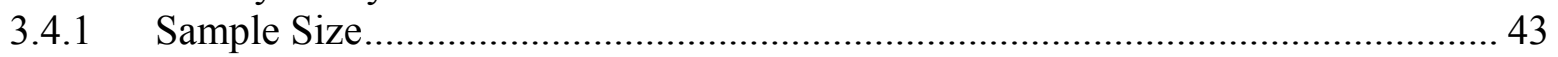

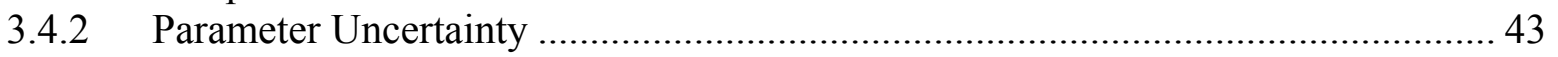

3.4.3 Alternative Monetary Value of Collective Dose .................................................... 44

3.4.4 Truncation of Collective Dose in Time .............................................................. 47

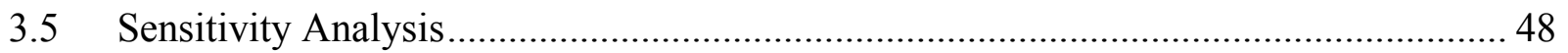

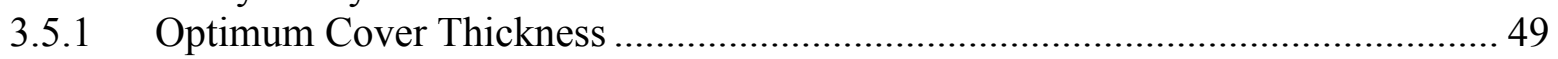

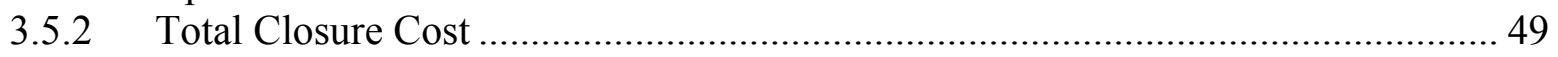

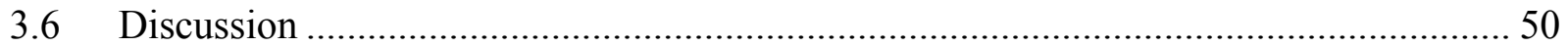

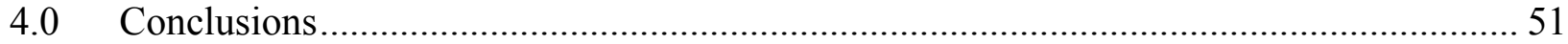

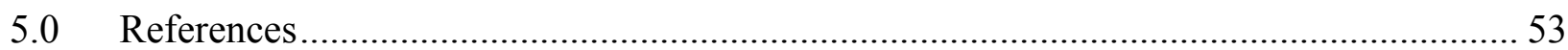

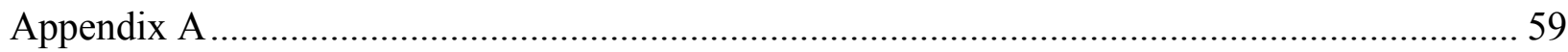

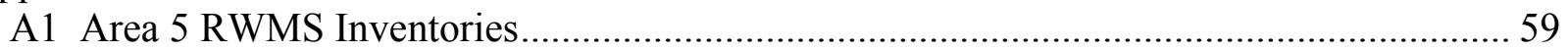

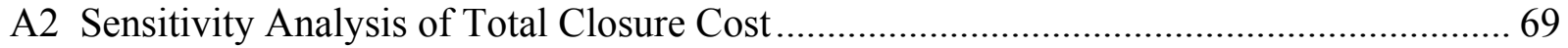

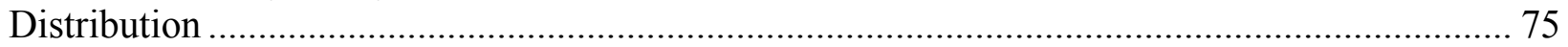




\section{LIST OF FIGURES}

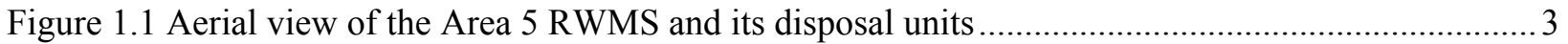

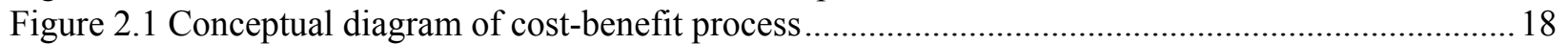

Figure 2.2 Algorithm for settlement of Frenchman Flat under the Jackass Flats scenario ...................... 23

Figure 2.3 Algorithm for settlement of Frenchman Flat under the Frenchman Flat community scenario .....25

Figure 2.4 Algorithm for optimization of cover thickness............................................................. 28

Figure 3.1 Empirical cumulative distribution function of the maximum onsite homesteader annual TEDE $(\mathrm{mSv})$ and onsite homestead well driller TEDE ( $\mathrm{mSv}$ per drilling event) for the Area 5 RWMS with a

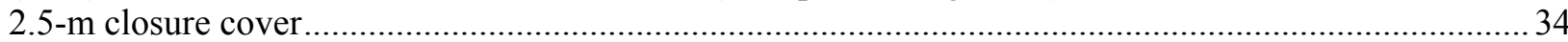

Figure 3.2 Collective dose over time for the Area 5 RWMS with a 2.5-m closure cover. Mean (solid blue), median (dashed blue), and $95^{\text {th }}$ percentile (dotted red) shown with 2,000 realizations (gray) .................. 35 Figure 3.3 Mean collective dose over time, disaggregated by subgroup for the Area 5 RWMS with a

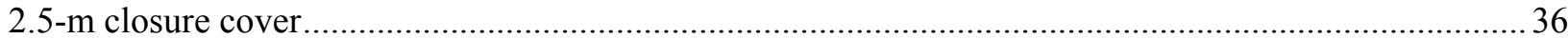
Figure 3.4 Mean onsite homesteader collective dose over time by radionuclide for the Area 5 RWMS

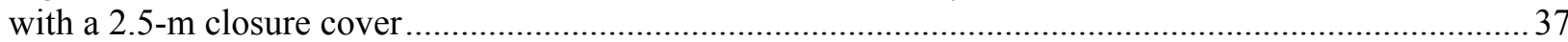
Figure 3.5 Mean offsite homesteader collective dose over time by radionuclide for the Area 5 RWMS

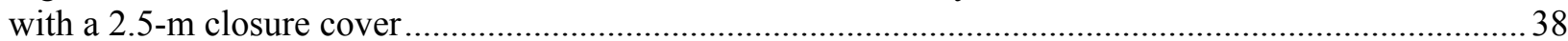
Figure 3.6 Collective dose versus cover thickness for the Area 5 RWMS. Mean (solid blue), median (dashed blue), and $95^{\text {th }}$ percentile (dotted red) shown with 2,000 realizations (gray) ............................. 39

Figure 3.7 Total closure cost versus cover thickness for closure of the 92-acre LLWMU....................... 40

Figure 3.8 Total cost versus cover thickness for closure of the Northern Expansion Area ...................... 41

Figure 3.9 Total cost versus cover thickness for closure of the entire Area 5 RWMS .............................. 42 Figure 3.10 Mean (green or blue), median (yellow), $10^{\text {th }}$ and $90^{\text {th }}$ percentiles (whiskers), and outliers (crosses) of the total closure cost for the Area 5 RWMS with a 2.5- and 4.5-m closure cover as a function

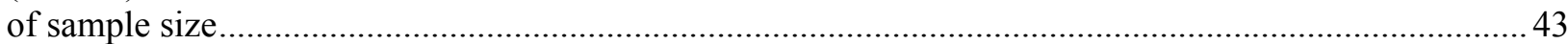
Figure 3.11 Total closure cost of the 92-ac LLWMU versus cover thickness assuming an upper limit

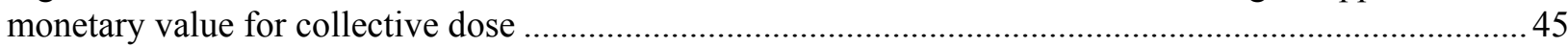
Figure 3.12 Total closure cost of the Northern Expansion Area versus cover thickness assuming an

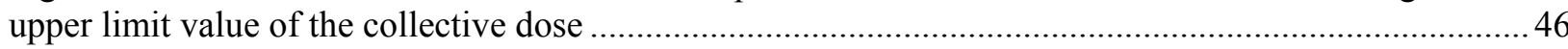
Figure 3.13 Total closure cost of the entire Area 5 RWMS versus cover thickness assuming an upper

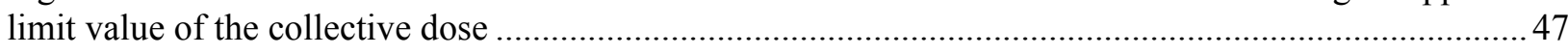
Figure 3.14 Total closure cost of the entire Area 5 RWMS versus cover thickness integrating collective

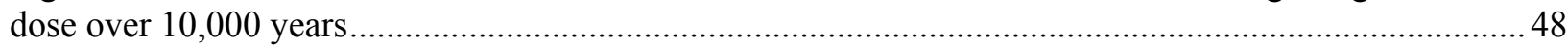
Figure A2.1 GBM predicted total closure costs versus GoldSim model result for the 92-ac LLWMU

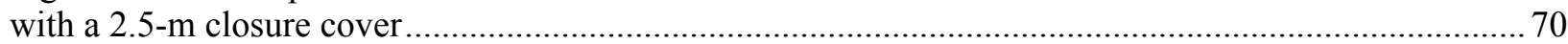
Figure A2.2 GBM predicted total closure costs versus GoldSim model result for the Northern

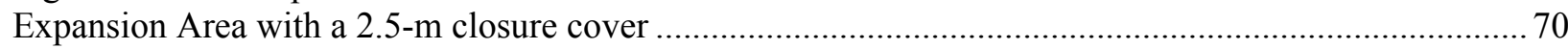
Figure A2.3 GBM predicted total closure costs versus GoldSim model result for the total Area 5

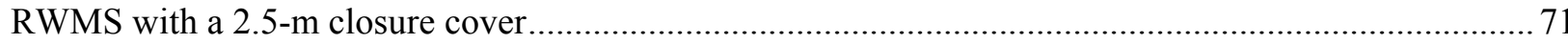

Figure A2.4 Density histogram (gray) and marginal dependence (blue) of the most sensitive parameters for the total closure cost for closure of the 92-ac LLWMU with a 2.5-m cover ................... 72 Figure A2.5 Density histogram (gray) and marginal dependence (blue) of the most sensitive parameters for the total closure cost for closure of the Northern Expansion Area with a 2.5-m cover ...... 72 Figure A2.6 Density histogram (gray) and marginal dependence (blue) of the most sensitive parameters for the total closure cost for closure of the total Area 5 RWMS with a 2.5-m cover .73 


\section{LIST OF TABLES}

Table 1.1 Expected and upper limit monetary value of a person-Sv in 1990 and in 2028 dollars.............. 7

Table 1.2 Estimated construction costs for the north and south 92-ac LLWMU cover............................ 8

Table 2.1 Geometric representation of the habitable area of Frenchman Flat .........................................26

Table 2.2 Assumed distribution for number of residents per household ...............................................22

Table 3.1 Performance assessment compliance evaluation for the post-1988 92-ac LLWMU inventory

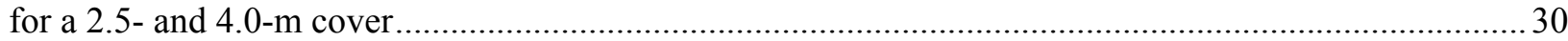

Table 3.2 Performance assessment compliance evaluation for the Northern Expansion Area inventory

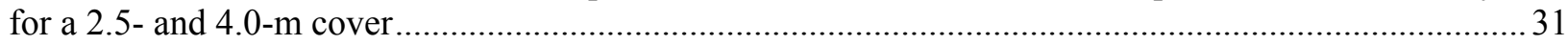

Table 3.3 Performance assessment compliance evaluation for the entire Area 5 RWMS post-1988

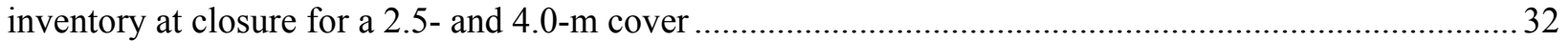

Table 3.4 Composite analysis evaluation for the entire Area 5 RWMS inventory at closure for a

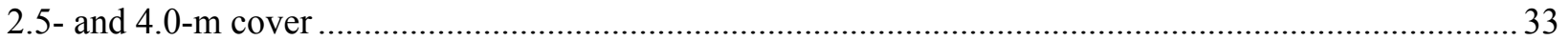

Table 3.5 Summary statistics for collective dose for the Area 5 RWMS .............................................. 34

Table 3.6 Summary statistics for total escalated closure costs for the 92-ac LLWMU........................... 40

Table 3.7 Summary statistics for total escalated closure costs for the Northern Expansion Area .............. 41

Table 3.8 Summary statistics for total escalated closure costs for the Area 5 RWMS ........................... 42

Table 3.9 Comparison of total closure costs for a 2.5-m cover on the 92-ac LLWMU assuming a representative and upper limit value of the monetary value of health detriment ..................................... 44

Table 3.10 Comparison of total closure costs for a 2.5-m cover on the Northern Expansion Area assuming a representative and upper limit value of the health detriment ............................................... 45

Table 3.11 Comparison of total closure costs for a 2.5-m cover on the Area 5 RWMS assuming a

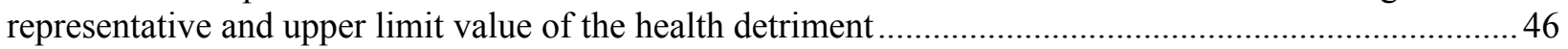

Table 3.12 Collective dose matrix for the Area 5 RWMS with a $2.5 \mathrm{~m}$ cover ....................................... 47

Table 3.13 Sensitivity analysis results for total closure costs with a 2.5 -m closure cover. ....................... 49

Table A1.1 Summary of analyses and inventories used for each analysis.............................................59

Table A1.2 Geometric mean and standard deviation of 500 LHS realizations of the pre-1988, post-1988,

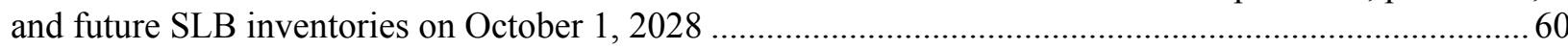

Table A1.3 Geometric mean and standard deviation of 500 LHS realizations of the Pit 6 and Pit 13

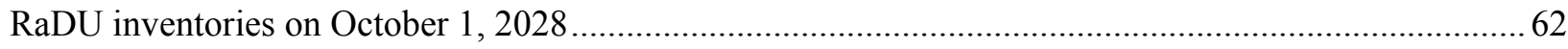

Table A1.4 Geometric mean and standard deviation of 500 LHS realizations of the GCD inventories on

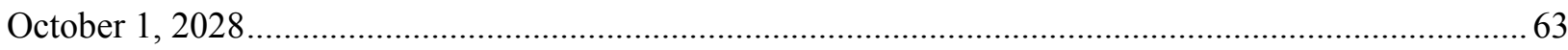

Table A1.5 Geometric mean and standard deviation of 500 LHS realizations of the 92-ac LLWMU and

the FY 2008 Northern Expansion Area SLB inventories on October 1, 2028......................................... 64

Table A1.6 Geometric mean and standard deviation of 500 LHS realizations of the post-1988 92-ac

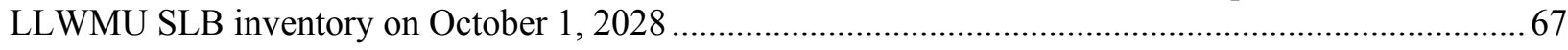

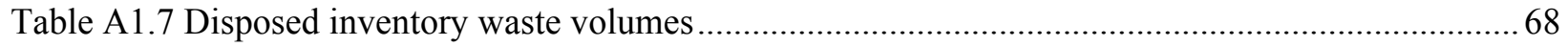




\section{ACRONYMS AND ABBREVIATIONS}

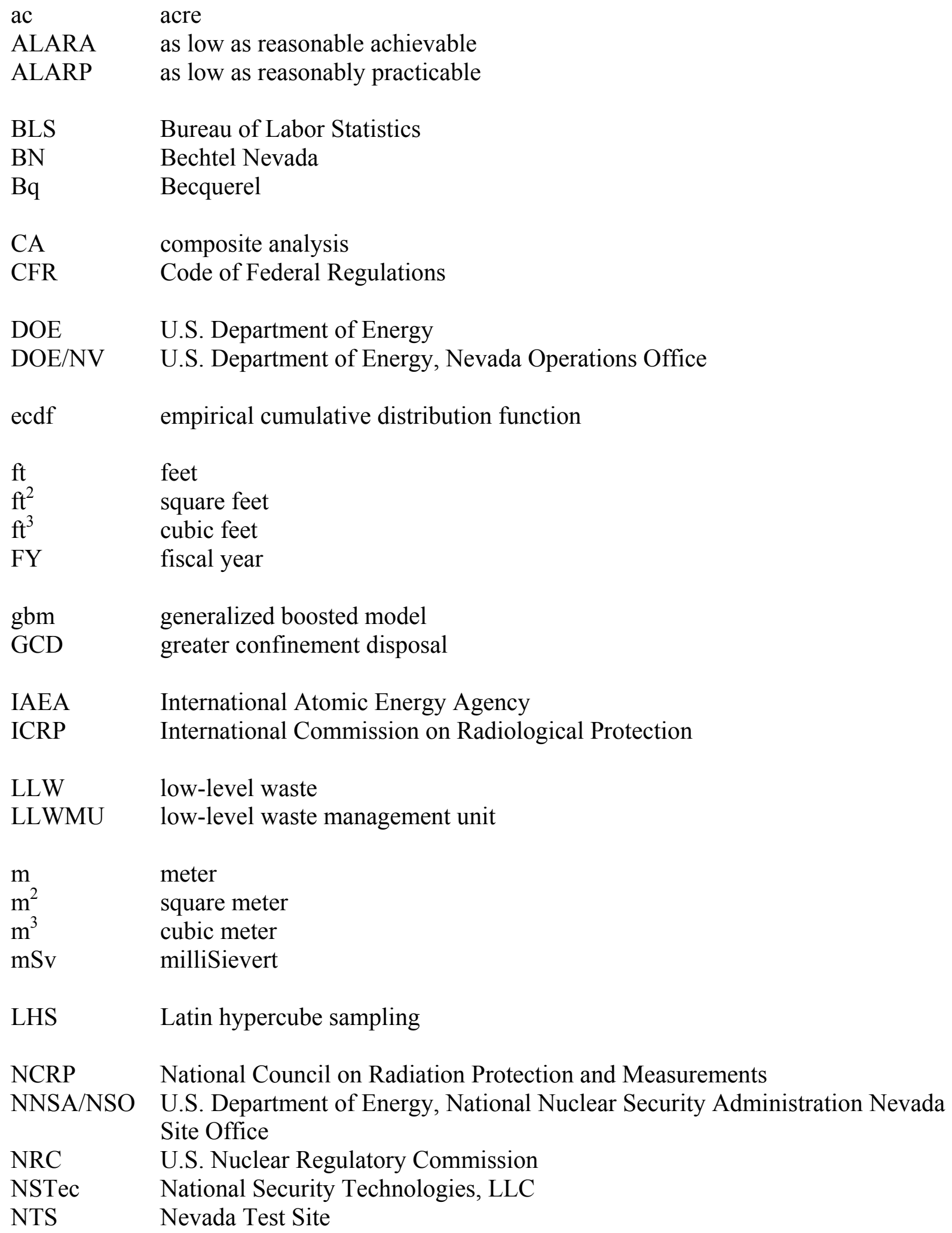




\section{ACRONYMS AND ABBREVIATIONS (CONTINUED)}

PA performance assessment

PDCF pathway dose conversion factor

pdf probability density function

RaDU radium disposal unit

REECo Reynolds Electrical and Engineering Company, Inc.

RWMS Radioactive Waste Management Site

SA special analysis

SLB shallow land burial

SME subject matter expert

Sv sievert

TEDE total effective dose equivalent

TRU transuranic 


\subsection{INTRODUCTION}

The International Commission on Radiological Protection (ICRP) has recommended a system of dose limitation in ICRP Publication 26 (ICRP, 1977), which has been widely implemented in U.S. radiation protection regulations. The three components of this system are currently (ICRP, 1990):

- Justification - No practice shall be adopted unless its introduction produces a positive net benefit.

- Optimization - Individual doses, the number of people exposed, and the likelihood of exposure shall be kept as low as reasonably achievable (ALARA), economic and social factors being taken into account.

- Limitation - The dose equivalent to individuals shall not exceed the limits recommended for the appropriate circumstances by the ICRP.

Radioactive waste disposed at the Area 5 Radioactive Waste Management Site (RWMS) is subject to the requirements of U.S. Department of Energy Order DOE O 435.1, "Radioactive Waste Management," and its accompanying manual, DOE M 435.1-1, "Radioactive Waste Management Manual" (DOE, 1999; 2001). DOE M 435.1-1 implements the ICRP optimization and limitation components in its performance objectives, which include dose limits for individuals and requirements to maintain releases of radionuclides to the environment ALARA. The process of maintaining releases ALARA is the balancing of the benefits of radiation protection against the costs.

Performance assessments (PAs) for the Area 5 RWMS have identified closure cover thickness as an important variable influencing member of public dose. This report evaluates the role of cover thickness in maintaining doses ALARA. The evaluation takes the form of a quantitative costbenefit analysis.

Unless stated otherwise, cover thicknesses given in this report are cover thickness above shallow land burial (SLB) disposal units at the Area 5 RWMS. SLB disposal unit covers begin 1.2 meters (m) (4 feet [ft]) below grade. Radium disposal units (RaDUs) and greater confinement disposal (GCD) boreholes have thicker covers, which can be calculated from the SLB disposal unit cover thickness by summing the depth of waste below grade and the above-grade thickness of the SLB cover.

\subsection{PROBLEM STATEMENT}

SLB disposal units, RaDUs, and GCD boreholes at the Area 5 RWMS are closed with operational covers ranging from 1.2 to $21 \mathrm{~m}$ (4 to $69 \mathrm{ft}$ ) thick. A final closure cover is required for the Area 5 RWMS that meets requirements for limitation (i.e., meets all applicable radiation protection standards) and optimization (i.e., maintains releases ALARA, economic and social factors being taken into account). A final closure cover thickness needs to be determined that meets these requirements for all disposal units on the Area 5 RWMS. Multiple PAs and composite analyses (CAs) have been prepared and approved that provide minimum cover thicknesses that meet applicable regulatory requirements. A final closure cover thickness that maintains releases ALARA remains to be determined. 


\subsection{GOALS OF OPTIMIZATION}

The goal of the optimization study is to provide the U.S. Department of Energy, National Nuclear Security Administration Nevada Site Office (NNSA/NSO) with the information needed to select a closure cover thickness that will maintain releases ALARA. The Area 5 RWMS will be closed in stages with the 92-acre (ac) Low-Level Waste Management Unit (LLWMU) closed first. Cover thickness will be optimized for the 92-ac LLWMU, Northern Expansion Area, and the entire Area 5 RWMS accounting for future waste disposals.

\subsection{THE ALARA PROCESS}

The ALARA process is a process of optimizing radiation protection (ICRP, 1983). The DOE M 435.1-1 performance objectives specifically require that releases of radionuclides be ALARA. This may imply a requirement to optimize radiation protection, while limiting options to those that reduce releases only. Under this interpretation, it would be appropriate to apply the ALARA process to an engineered barrier designed to contain waste, but would be inappropriate to consider options that reduce the likelihood of exposure of the public, such as institutional controls. Presumably, the optimization of the engineered barrier would still be evaluated in terms of the individual doses, the number of people exposed, and the likelihood of exposure.

Although ALARA has been a central tenet of ICRP recommendations since the 1970s, the concept has evolved over time. Early recommendations emphasized control of societal risks through the use of quantitative cost-benefit analysis based on collective dose (ICRP, 1977; 1983). Since then the ICRP has recognized that individual risk must also be considered (ICRP, 1991) and has recommended that protection options be constrained by individual dose (ICRP, 2005; 2007a). Most recently, the process has been broadened to include a range of qualitative and quantitative approaches that include accident avoidance, adoption of a safety culture, and inclusion of stakeholders in the decision-making process (ICRP, 2005; 2007a).

This report describes the quantitative cost-benefit analysis component of the ALARA process applied to closure cover thickness at the Area 5 RWMS. ALARA cost-benefit analysis compares alternative radiation protection options to find the most cost-effective option.

\subsection{AVAILABLE DATA}

The following sections summarize existing information and data relevant to selection of a final closure cover thickness.

\subsubsection{Site Description}

The Area 5 RWMS, located in Northern Frenchman Flat on the Nevada Test Site (NTS), has been operated by the DOE and its predecessors since 1961 for the disposal of low-level waste (LLW), mixed low-level waste, and transuranic (TRU) waste. Wastes are disposed in shallow unlined trenches and deep GCD boreholes.

The Area 5 RWMS consists of the 92-ac LLWMU and the Northern Expansion Area (Figure 1.1). Separate closure covers are planned for both areas. 


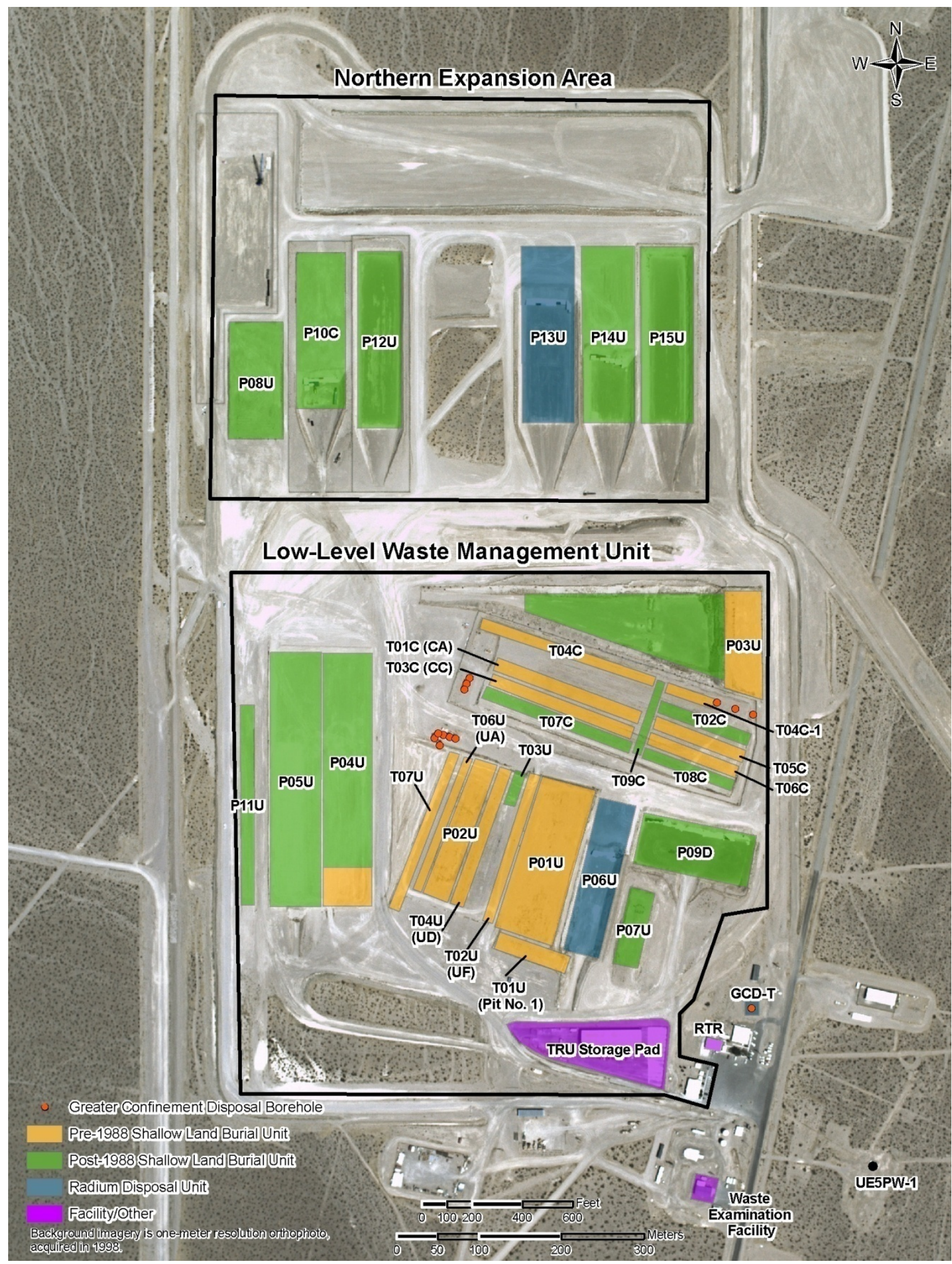

Figure 1.1 Aerial view of the Area 5 RWMS and its disposal units 
The 92-ac LLWMU consists of 12 pre-1988 SLB disposal units, 9 post-1988 SLB disposal units, and 2 SLB disposal units containing both pre- and post-1988 waste. A single RaDU, Pit 6 (P06U), contains thorium waste in a lower cell beneath asbestiform LLW. RaDUs have thicker covers to reduce radon-222 $\left.{ }^{222} \mathrm{Rn}\right)$ emissions. High specific activity waste is disposed in 10 GCD boreholes, including 4 that contain TRU waste. A small quantity of TRU waste was inadvertently buried in classified Trench 4 (T04C), a pre-1988 SLB disposal unit.

The Northern Expansion Area currently consists of six SLB disposal units. The northern portion of Pit 13 (P13U), contains a single layer of thorium waste disposed $5.4 \mathrm{~m}(17.7 \mathrm{ft})$ below grade to control ${ }^{222} \mathrm{Rn}$ emissions and is designated as a RaDU. All future disposal units are assumed to be in the Northern Expansion Area.

\subsubsection{Site Characterization}

The geologic and hydrologic setting of the Area 5 RWMS is extensively characterized (Reynolds Electrical and Engineering Company, Inc. [REECo], 1993; 1994; Istok et al., 1994; Blout et al., 1995). The site is underlain by a thick, dry vadose zone of unconsolidated alluvium, with the uppermost aquifer occurring 236 to $256 \mathrm{~m}$ (774 to $840 \mathrm{ft}$ ) below the surface. Site characterization data indicate that sparse desert precipitation is efficiently returned to the atmosphere by evapotranspiration before reaching the bottom of the plant rooting zone (Shott et al., 1998; Walvoord et al., 2002). Under current climatic conditions, no transport pathway exists between buried waste and the uppermost aquifer.

Site characterization data have been used to develop a conceptual model of site performance. Multiple PAs and a CA have been prepared, reviewed, and approved using the site conceptual model (Bechtel Nevada [BN], 1998; 2001b; 2006; Cochran et al., 2001). The current PA/CA model is implemented in the probabilistic GoldSim modeling platform. The current version, used in the cover optimization, is the A5 RWMS GoldSim model, version 4.102.

Site characterization and monitoring are ongoing processes attempting to reduce important PA uncertainties and confirm expected facility performance. The results of continuing site characterization and model updating are described in annual summary reports (National Security Technologies, LLC [NSTec], 2007; 2008a). Environmental monitoring results are also summarized and reported annually (NSTec, 2008b; 2008c).

\subsubsection{Previous Performance Assessment Results}

PA models and their parameters are not static but change over time as new data and research results are incorporated in revised models. In spite of these changes, previous PA results provide an indication of the range of suitable cover thickness options (Shott et al., 1998; 2008; BN, 2006). The final options selected still need to be tested with the current PA model to confirm that all performance objectives can be met.

The most recent Area 5 RWMS PA evaluated the optimum cover thickness for the post-1988 SLB closure inventory (BN, 2006). The PA determined that the mean results with a $2.5-\mathrm{m}$ (8.2-ft) cover met all performance objectives. Performance of the $2.5-\mathrm{m}(8.2-\mathrm{ft})$ cover at the $95^{\text {th }}$ percentile level was less than all performance objectives, except for the intruder-agriculture 
scenario, which required a 3-m (9.8-ft) cover. The optimum closure cover thickness for the SLB disposal units was less than $2.5 \mathrm{~m}(8.2 \mathrm{ft})$.

The TRU waste in GCD boreholes is subject to the requirements of Title 40 Code of Federal Regulations (CFR) Part 191, "Environmental Radiation Protection Standards for Management and Disposal of Spent Nuclear Fuel, High-Level and Transuranic Radioactive Wastes" (CFR, 1991). The PA for the GCD boreholes assumed that the Area 5 RWMS would be closed with an alluvium monolayer cover extending $2.0 \mathrm{~m}$ (6.6 ft) above existing grade (Cochran et al., 2001). A cover $2 \mathrm{~m}(6.6 \mathrm{ft})$ above grade corresponds to a 3.2-m (10.5-ft) cover over the SLB disposal units and a 23-m (75-ft) cover for the GCD disposal units. The GCD PA determined that the 40 CFR 191 Cumulative Release and Individual Protection Standards would be met with this cover.

A small quantity of TRU waste was inadvertently disposed in classified SLB Trench 4 (T04C). A special analysis (SA) of this waste evaluated the potential to meet all the requirements of 40 CFR 191 (Shott et al., 2008). The SA was performed to inform NNSA/NSO about the risk posed by the buried TRU waste. The 40 CFR 191 standard is not considered a strictly applicable regulatory requirement for this waste. The SA concluded that a 2.8-m (9.2-ft) thick cover was required to meet the 15 milliSievert $(\mathrm{mSv})$ Individual Protection Requirements. The SA also ranked alternative engineered barriers with respect to their cost-effectiveness. Three barriers were ranked higher than a 2.8-m (9.2-ft) alluvium monolayer cover. In descending order of cost-effectiveness, the preferred alternatives were a 4-m (13-ft) alluvium monolayer cover, a 4-m (13-ft) alluvium monolayer cover with a boulder mound intruder barrier, and a 4-m (13-ft) alluvium monolayer cover with a boulder field intruder barrier.

\subsection{ADDITIONAL DATA}

Completion of the cover optimization requires additional data not previously described. The following sections describe new data and their sources.

\subsubsection{Site Inventory}

The Area 5 RWMS is currently planned to be closed in two phases (BN, 2005). The first phase, planned for Fiscal Year (FY) 2011, is closure of the 92-ac LLWMU. The design for the 92-ac LLWMU includes a northern cover for Pit 3 (P03U) and the classified units, and a southern cover for all other units. The second phase will be closure of the Northern Expansion Area in FY 2028.

Inventory estimates are usually prepared to assess compliance with PA or CA requirements. These inventory estimates are usually broken down by period of disposal (e.g., pre-1988, post-1988), disposal unit design (e.g., SLB, GCD), and waste type (e.g., LLW, TRU). Because the cover optimization will consider the 92-ac LLWMU, the Northern Expansion Area, and the total Area 5 RWMS covers, new inventories broken down by geographic area (e.g., 92-ac LLWMU, Northern Expansion Area) and disposal unit design must be prepared.

The volume and inventory of wastes disposed in the Area 5 RWMS are recorded in three databases that cover different periods of operation. Although volume and activity records are believed to be relatively complete, early database records do not consistently record the disposal 
location, making it difficult to develop accurate inventories for individual disposal units. Records from the period of operation of the Northern Expansion Area, however, are complete, allowing estimation of the 92-ac LLWMU SLB inventory as the difference between the total Area 5 RWMS SLB inventory and the Northern Expansion Area SLB inventory.

The required site inventories are estimated using the Area 5 Inventory GoldSim model, version 2.104 (BN, 2006). The inventories are estimated probabilistically and decayed to the assumed date of closure in FY 2028. The inventories, their uncertainties, and application in the optimization study are summarized in Appendix A1.

\subsubsection{Monetary Value of Health Detriment}

Optimization by cost-benefit analysis requires that a monetary value be assigned to the health detriment of radiation exposure. The primary health detriment from low-level radiation exposure is cancer, but hereditary effects and risk aversion are other potentially detrimental impacts. The health detriment is assessed by calculating the collective dose in units of person-sievert (Sv). The monetary value of the health detriment is set by selecting a conversion factor (or function) that converts person-Sv into dollars.

A subjective approach must be used to assign a monetary value to collective dose, because no market exists where health detriment is bought or sold (Hanley, 1992; French et al., 2005). Morgan and Henrion (1990) have described parameters that are highly dependent on a decision maker's subjective views as value parameters. They argue that value parameters are best addressed using discrete parameter values representing the different positions of interested parties. Performing the optimization at the different discrete values can determine if the different opinions impact the final decision. If the same decision is indicated for each level of the value parameter, then the disagreement is inconsequential. If the differences are important, the final option selected transparently indicates how the decision maker weighed the different opinions. This approach also directly acknowledges the subjective nature of cost-benefit analysis and identifies the important subjective values entering the decision. Therefore, the optimization uses discrete values of the monetary value of health detriment representing a range of opinions, rather than a probability density function (pdf).

The monetary value of health detriment is commonly determined by estimating the value society places on reducing the risk of mortality. This value, termed the value of a statistical life because it represents the value of a hypothetical person in a population rather than a specific individual, is multiplied by the cancer mortality risk per radiation exposure to obtain a dollar per person-Sv conversion factor. Based on reviews of multiple estimates of the value of a statistical life, regulatory agencies in the U.S. have consistently selected a health detriment monetary value of $\$ 200,000$ person $^{-1} \mathrm{~Sv}^{-1}$, explicitly subject to present worth considerations in the case of the U.S. Nuclear Regulatory Commission (NRC) (NRC, 1995; DOE, 1997). The preponderance of data in these studies are based on 1990 valuations (NRC, 1995; Guenther and Thein, 1997). Both agencies have indicated that this value is appropriate for environmental exposures.

Review of the literature indicates a maximum value of a statistical life of $\$ 300$ million in 1990 dollars (Guenther and Thein, 1997; Hardeman et al., 1998; Eged et al., 2001; Katona et al., 2003). Multiplying by a radiation risk coefficient of $0.05 \mathrm{~Sv}^{-1}$ (Guenther and Thein, 1997), an 
upper limit cost of $\$ 15,000,000$ person $\mathrm{Sv}^{-1}$ is obtained. It is unlikely that DOE decision makers would consider a value less than recommended by guidance. Therefore, a lower limit is not estimated.

The monetary value of health detriment has been proposed (Schneider et al., 1997) to increase with individual dose above a threshold dose where risk aversion becomes important as:

$$
\alpha= \begin{cases}\alpha_{\text {base }} & H \leq H_{o} \\ \alpha_{\text {base }}\left(\frac{H}{H_{o}}\right)^{a} H>H_{o}\end{cases}
$$

where $\alpha$ is the monetary value of the health detriment, $H$ is the individual dose equivalent, $H_{o}$ is the risk aversion dose equivalent threshold, and $a$ is the risk aversion factor.

The threshold for risk aversion has been estimated to fall in the range of $1-0.2 \mathrm{mSv}$, which is in the range of environmental radiation protection standards (Hardeman et al., 1998; Eged et al., 2001; Katona et al., 2003). Presumably, there is little risk aversion at levels of exposure allowed for the general public. Since the optimization must meet all regulatory limits, individual doses in the optimization study are likely less than the threshold for risk aversion and a constant monetary value of health detriment can be assumed.

There are 38 years between the final closure date, 2028, and the 1990 valuation of the monetary value of health detriment. Although considerable escalation in the value of the health detriment may occur over this interval, present worth considerations will tend to compensate for the increases (NRC, 1995). Nevertheless, the monetary value of health detriment is escalated due to the number of years and uncertainty in the discount rate. The future monetary value of the health detriment can be calculated as:

$$
\alpha_{F}=\alpha_{P}(1+\gamma)^{n}
$$

where $\alpha_{F}$ is the future (i.e., 2028) monetary value, $\alpha_{P}$ is the 1990 value, $\gamma$ the escalation rate, and $n$ the number of years. There is no guidance on the appropriate escalation rate. The 2028 value was estimated by using the Bureau of Labor Statistics (BLS) consumer price index inflation calculator (BLS, 2008) for 1990 through 2008 and assuming an annual inflation rate of 0.038 from 2009 to 2028. Guenther and Thein (1997) have observed that 4 percent is a reasonable escalation rate for the value of a statistical life. Using the method above, the 2028 monetary value of the health detriment in Table 1.1 can be estimated.

Table 1.1 Expected and upper limit monetary value of a person-Sv in 1990 and in 2028 dollars

\begin{tabular}{|c|c|c|}
\hline Value & 1990 Value $\left(\$\right.$ person $\left.^{-1} \mathrm{~Sv}^{-1}\right)$ & 2028 Value $\left(\$\right.$ person $\left.^{-1} \mathrm{~Sv}^{-1}\right)$ \\
\hline Expected Value & 200,000 & 684,000 \\
\hline Upper Limit & $15,000,000$ & $51,300,000$ \\
\hline
\end{tabular}




\subsubsection{Cover Construction Costs}

The cost of constructing a 2.5- and 3.0-m (8.2- and 9.8-ft) thick north and south cover over the 92-ac LLWMU was estimated by NSTec, assuming that the three open disposal units (i.e., P09U, P06UA, and P03U) were filled at the time of closure and that preparation of top soil for revegetation is unnecessary (NSTec, 2008d; 2008e) (Table 1.2). The 2.5- and 3.0-m (8.2- and 9.8-ft) 92-ac LLWMU covers were estimated to have a 70-ac footprint and require additional fill of 23,209 and 105,245 cubic meters $\left(\mathrm{m}^{3}\right)\left(819,618\right.$ and 3,716,692 cubic feet [ $\left.\mathrm{ft}^{3}\right]$, respectively. The cost estimates address cover construction, revegetation, site grading, site drainage, fencing, and laboratory testing.

Table 1.2 Estimated construction costs for the north and south 92-ac LLWMU cover

\begin{tabular}{|c|c|c|c|}
\hline Cost Category & Task & $\begin{array}{c}\text { 2.5-m Cover } \\
\text { (\$ millions) }\end{array}$ & $\begin{array}{c}\text { 3.0-m Cover } \\
\text { (\$ millions) }\end{array}$ \\
\hline \multirow{12}{*}{ Direct Costs } & Earthwork & 0.082 & 0.40 \\
\hline & Construction Equipment & 0.43 & 1.01 \\
\hline & Fencing & 0.28 & 0.28 \\
\hline & Grading & 0.007 & 0.007 \\
\hline & Landscaping & 0.21 & 0.21 \\
\hline & Drainage & 0.075 & 0.075 \\
\hline & Electrical Preparation & 0.005 & 0.005 \\
\hline & Construction Facilities & 0.033 & 0.033 \\
\hline & Construction Services/Support & 0.053 & 0.077 \\
\hline & Mobilization & 0.004 & 0.004 \\
\hline & Project Management/Engineering & 0.25 & 0.31 \\
\hline & Total Direct Costs & 1.4 & 2.4 \\
\hline \multirow{5}{*}{ Indirect Costs } & EM Support & 0.078 & 0.12 \\
\hline & Infrastructure & 0.49 & 0.76 \\
\hline & Construction & 0.090 & 0.15 \\
\hline & Fixed Fee & 0.14 & 0.23 \\
\hline & Total Indirect Costs & 0.8 & 1.3 \\
\hline Management Reserve & Estimate Contingency (Uncertainty) & 0.73 & 1.2 \\
\hline Escalation & Cost Escalation to Construction in 2011 & 0.30 & 0.5 \\
\hline Total & Total Cost & 3.2 & 5.4 \\
\hline
\end{tabular}

\subsection{STUDY BOUNDARIES}

This section describes the limits and boundaries of the optimization process.

\subsubsection{Cover Options}

The current Area 5 RWMS PA assumes a 4-m (13-ft) closure cover, but previous analyses have suggested that reasonable assurance of compliance can be obtained with thinner covers (BN, 2006). Therefore, the range of cover options considered is from the minimum cover thickness that the GoldSim model can evaluate $(2.5 \mathrm{~m}[8.2 \mathrm{ft}])$ to an upper limit bounding the present cover thickness $(4.5 \mathrm{~m}$ [15 ft]). Initially five equally spaced options $(2.5,3.0,3.5,4.0$, 
and $4.5 \mathrm{~m}[8.2,9.8,11,13$, and $15 \mathrm{ft}])$ will be considered unless results indicate that additional data are necessary.

Cover thicknesses are given, unless otherwise stated, as the distance between buried waste and the surface over a SLB disposal unit. Cover thicknesses of deeper disposal units such as RaDUs or GCDs can be calculated as the depth of the deeper unit's waste below grade plus the abovegrade thickness of SLB disposal units. The above-grade thickness of SLB disposal units is the total SLB cover thickness less the $1.2 \mathrm{~m}(4 \mathrm{ft})$ below-grade thickness.

\subsubsection{Site Inventory}

Site inventory is developed for two regions of the Area 5 RWMS, the 92-ac LLWMU and the Northern Expansion Area. The 92-ac LLWMU inventory is partitioned into three virtual units with similar depths of burial, the SLB units, the Pit 6 RaDU, and the GCD boreholes. It is assumed that any waste disposed in the 92-ac LLWMU between FY 2008 and FY 2010 will have negligible impact of the total closure waste volume and inventory. The Northern Expansion Area inventory consists of the disposed SLB inventory, the Pit 13 (P13U) RaDU, and the future SLB inventory forecast until 2028.

\subsubsection{Representative Persons}

The population of persons exposed to contamination released from the Area 5 RWMS will be composed of individuals with different ages, weights, genders, and habits such as food intake rates or time spent outdoors. The differences among individuals will cause each individual in the population to receive a different dose. The distribution of doses within the population represents variability or the true heterogeneity that exists within a population. Calculating or simulating the dose for each individual in a population can be extremely complex. In practice, collective dose is usually calculated using the mean dose for populations that have been disaggregated into groups with reasonably homogenous doses (International Atomic Energy Agency [IAEA], 2001; Smith et al., 2007). The regulatory end point of DOE M 435.1-1 PAs is also a single fixed dose (presumably with uncertainty) that represents the dose for an average adult assuming average living habits and exposure conditions. Although it has been shown that internal dose conversion factors are sensitive to age (ICRP, 2007b), DOE has only approved dose conversion factors for adults (DOE, 2001). In addition, draft DOE guidance for application of ALARA optimization to environmental compliance recommends calculating a dose for an average or typical receptor (DOE, 1997).

For the reasons cited above, intra-population variability is not explicitly considered in the collective dose calculation. Input parameters for the characteristics and habits of individuals are selected as the fixed mean of the exposed adult population or as a pdf expressing uncertainty in the mean. The model result is a distribution of the collective dose representing uncertainty (i.e., lack of knowledge) about the collective dose calculated for a population consisting of average adults with average living habits. The exposed population will be disaggregated into sub-groups expected to receive similar doses based on shared locations and activities. 


\subsubsection{Temporal Boundaries}

Collective dose is the sum of the dose rates of every individual in a population integrated over time. The long time periods that some radionuclides may remain hazardous (e.g., uranium-238

$\left.{ }^{238} \mathrm{U}\right]$ with half-life $=4.5 \mathrm{E} 9$ year) may require integration over immense periods. Over such long time intervals, prediction of geologic, climatic, and demographic conditions and even health risk coefficients becomes speculative. The uncertainty in the collective dose increases as the period of integration increases. Eventually, uncertainty makes it impossible to distinguish among different radiation protection options. This argues that collective dose should be truncated in time, at least when radiation protection options are being compared.

An alternative view exists, based on the internationally accepted dose-response model for the stochastic risks of radiation exposure. This model, known as the linear no-threshold model, holds that risks increase linearly with dose and have no threshold. This implies that all doses, no matter how small, impart risk, and truncation in time is inappropriate (Fairlie and Sumner, 2000).

The ICRP has proposed that collective dose be reported in a dose matrix (ICRP, 2005). Each element in the matrix is the collective dose calculated for a particular time interval and population. Decision makers can then apply weights to each element in the matrix reflecting the uncertainty for the given population and time period. The disadvantage of this approach is that no objective method exists for assigning the weights to the different matrix elements.

In practice, collective dose is usually truncated at a few hundred years to limit uncertainty (Barraclough et al., 1996; DOE, 1997; Dunster, 2000; Smith et al., 2007). The Area 5 RWMS model has time limitations beyond which its results can no longer be considered valid. Integration of collective dose to its infinite limit will introduce unacceptable uncertainty, requiring that a time limit for truncation be selected. The present optimization is being performed under DOE M 435.1-1, which uses a compliance period of 1,000 years. The Area 5 RWMS model has been developed explicitly for this time period. Therefore, collective dose will be truncated at 1,000 years.

\subsubsection{Spatial Boundaries}

The number of individuals contributing to the collective dose increases as the spatial boundaries of the analysis expands. The dose to individuals, however, will decrease as the distance from the Area 5 RWMS increases. If the spatial limits are expanded globally, most of the collective dose will be contributed by a large number of individuals with extremely low doses. Therefore, the question of spatial limits is related to the minimum individual dose that should be included in the collective dose.

Truncation of the collective dose based on the individual dose is also a potential difficulty. The linear no-threshold hypothesis implies that no dose is too small to be ignored and that all doses should be included in the collective dose. Practical experience has shown that including all individual doses in the collective dose leads to expenditures that most would agree are unreasonable (Barraclough et al., 1996; Fairlie and Sumner, 2000; Lindell, 2000). The ICRP has found that inclusion of large numbers of trivial individual doses in the collective dose calculation, which can occur with unlimited spatial boundaries, is an abuse of the collective dose concept (ICRP, 2007a). 
The idea of a trival (de minimus) dose can be used to resolve the contradiction between the linear no-threshold hypothesis, which requires that every dose be included, and practical results that suggest using every dose leads to unreasonable conclusions. A de minimus dose is based on the assumption that there is a dose threshold below which individuals perceive no significant risk. Doses that are a small fraction of background doses have been proposed as consistent with this definition. While a de minimus dose may imply some small risk, they can be excluded from regulation and control because individuals perceive them to be trivial.

The optimization will truncate trivial doses from the collective dose by selecting spatial limits that include some individuals receiving doses that are a small fraction of background exposure. Presumably, populations beyond these limits will have even lower individual doses that do not need to be included in the collective dose. Average annual U.S. background radiation exposure is currently estimated to be $3.6 \mathrm{mSv}$ (National Council on Radiation Protection and Measurements [NCRP], 1987). A de minimis limit of one percent of background would be approximately $0.03 \mathrm{mSv}$. Based on previous PA results, spatial limits that include Frenchman Flat, Jackass Flats, and Mercury should include all individual doses above this limit. This preliminary conclusion can be tested by examining individual doses in these populations.

\subsubsection{Radon in Air}

Inhalation of ${ }^{222} \mathrm{Rn}$ and its short-lived progeny in air is a potentially important source of dose from disposed LLW. The risk from exposure to ${ }^{222} \mathrm{Rn}$ in air from multiple waste types, including DOE-regulated LLW, has been managed by applying a 0.74 Becquerel $(\mathrm{Bq}) \mathrm{m}^{-2} \mathrm{~s}^{-1}{ }^{222} \mathrm{Rn}$ flux limit. Based on the precedence that inhalation of ${ }^{222} \mathrm{Rn}$ and its progeny is generally excluded from environmental radiation protection standards, the cover thickness optimization does not include the dose from ${ }^{222} \mathrm{Rn}$ and its short-lived progeny in air. 
This Page Intentionally Left Blank 


\subsection{METHOD}

Section 2.0 summarizes the development and implementation of the methods used to optimize cover thickness for the Area 5 RWMS.

\subsection{METHOD OVERVIEW}

The optimization uses cost-benefit analysis to select the cover thickness that maximizes the net benefit of operation of the Area 5 RWMS. In cost-benefit analysis, the net benefit is the gross benefit less the production costs, the radiation protection costs, and the health detriment costs. When the goal is to optimize radiological protection only, variables that are independent of the level of radiation protection, such as the gross benefit (e.g., national security benefits from operation of the Area 5 RWMS) and production costs (e.g., site operating costs excluding radiological protection), can be removed from the model. In such a simplified model, the optimum cover minimizes the total cost, which is the sum of the radiation protection costs and the health detriment costs (ICRP, 1983). The radiation protection costs are costs associated with the design, construction, and maintenance of the cover. The health detriment costs are costs associated with the health risks to workers and the public from exposure to ionizing radiation. The required inputs for the cost-benefit optimization are the cover construction costs and health detriment costs as a function of closure cover thickness.

The cover construction costs are estimated by a model that scales direct and indirect construction costs based on cover area and thickness. The scaling factors are derived from two cost estimates prepared for a 2.5- and 3-m (8.2- and 9.8-ft) cover on the 92-ac LLWMU. As only two data points are available, costs are assumed to scale linearly with cover thickness and area.

The health detriment costs are estimated by multiplying the collective dose by a dollar per collective dose factor. Collective dose is the sum of all the dose rates of the individuals in a population, integrated over time. Collective dose has units of person-Sv. Calculation of the collective dose is simplified by disaggregating the exposed populations into sub-groups that are expected to receive similar doses based on their activities or the environmental concentrations where they reside. Under this simplified approach, the collective dose of a sub-group is calculated by multiplying the mean population dose rate by the sub-group size and integrating over time.

To calculate the collective dose, the model must simulate and track for each sub-group the population size, population location, and environmental media concentrations over time. Future settlement is simulated using GoldSim's discrete event simulation capabilities. Looping containers triggered by settlement events are used to stochastically locate homesteads and select population sizes. Population sizes are tracked in time using GoldSim reservoir elements. Discrete change elements add residents to a population reservoir upon settlement, and discrete change delay elements remove population when the stochastic community lifetime has expired. Settlement on the Area 5 RWMS results in the exposure of a drill crew and transfer of buried contamination to the surface soil of a contaminated home site. The collective dose rate is calculated at each model step as the product of the population size and average population dose rate. The total collective dose is obtained by integrating the collective dose rate over time. 


\subsection{MODEL DEVELOPMENT}

\subsubsection{Inventory Models}

The current Area 5 RWMS Inventory GoldSim model can estimate the total Area 5 RWMS inventory. New inventories must be estimated for the 92-ac LLWMU SLB disposal units, the post-1988 92-ac LLWMU SLB disposal units, and the Northern Expansion Area SLB disposal units. Database integrity problems for pre-1993 records make it difficult to estimate the 92 -ac LLWMU inventories directly from database queries. Conceptually, the 92-ac LLWMU SLB inventory is the pre-1988 SLB inventory plus the post-1988 SLB less the inventory of the Northern Expansion Area SLB units (i.e., P08U, P10C, P12C, P14U, P15U, P16U, and P16C). The Northern Expansion Area inventory is the sum of the SLB disposal unit inventory, the Pit 13 inventory, and the future inventory.

The pre- and post-1988 SLB inventories are already available in the Area 5 RWMS Inventory GoldSim model. The Northern Expansion Area SLB inventory was obtained from the database records and added to the inventory model. The 92-ac LLWMU inventories are estimated as the SLB inventory less the Northern Expansion Area SLB inventory. The Northern Expansion Area SLB inventory is estimated as the disposed inventory in database records plus the future inventory estimate.

\subsubsection{Future Settlement Model}

The conceptual model of Frenchman Flat settlement is based on the elicitation of a panel of subject matter experts (SMEs) conducted to estimate the probability of drilling intrusion at the Area 5 RWMS (Black et al., 2001). The SMEs considered four settlement scenarios:

- A homesteader scenario where a single independent residence is established in Frenchman Flat.

- A base case community scenario where a community is established in Frenchman Flat.

- The Jackass Flats scenario where individual independent homesteads are established in Frenchman Flat by individuals commuting to work at a community in Jackass Flats or at Mercury.

- The Las Vegas expansion scenario where individual homesteads are established in Frenchman Flat by individuals commuting to work in an expanded Las Vegas metropolitan area.

The SMEs scenarios describe two patterns of settlement in Frenchman Flat: individual, independent homesteads (i.e., the homestead, Jackass Flats, and Las Vegas expansion scenarios) and a community (i.e., base case community scenario). Statistical simulations using the opinions of the SMEs indicate that the Jackass Flats scenario is overwhelmingly the most probable scenario (Black et al., 2001). Therefore, among homesteader scenarios it is sufficient to consider the Jackass Flats scenario only. Although the base case community scenario has a comparatively small probability, it may have significantly higher consequence because it exposes a larger population, and the collective dose is a function of the number of persons exposed. Therefore, 
the base case community scenario is also included because its higher consequence may present a risk comparable to the Jackass Flats scenario.

The SMEs concluded that a Jackass Flats community would most likely be present for 50 percent of the next 10,000 years. The range of times a community would be present was expected to range from 25 to 75 percent. The SMEs also believed that homesteads in Frenchman Flat would be present as long as the Jackass Flats community was present. The SMEs concluded that an independent community in Frenchman Flat would most likely be present for 50 to 100 years over the next 10,000 years.

Settlement is assumed to occur randomly in time. As the Frenchman Flat basin offers no attractive resources, homesteads and communities are assumed to occur randomly within the habitable portion of the basin. The habitable area is the valley bottom, excluding the playa.

The lifetime of each settlement is also based on the opinions of the SMEs who felt that communities would have a median lifetime of 50 years. The SMEs also indicated that homesteads in Frenchman Flat associated with a community in Jackass Flats or Mercury would persist as long as the community.

Institutional controls are assumed to eliminate the possibility of onsite drilling and residences as long as controls are effective. Offsite settlement in Frenchman Flat, Jackass Flats, or Mercury is assumed to be possible immediately after closure.

\subsubsection{Release and Transport Model}

The optimization uses the Area 5 RWMS PA release and transport model (BN, 2006). The Area 5 RWMS PA model assumes that there is no groundwater pathway and that all release pathways move contamination upwards to the land surface. Upward transport is assumed to occur by:

- Advection of water driven evapotranspiration at the surface. Liquid advection is assumed to stop at the no-liquid-flux-boundary corresponding with the base of the plant root zone.

- Diffusion in the liquid and air phase. Liquid diffusion is assumed to stop at the no-liquidflux-boundary due to the dry conditions and highly disconnected state of the liquid phase.

- Burrowing insects and mammals are assumed to transport subsurface contamination to the surface. Collapsing burrows are assumed to be in-filled by soil from the overlying layer.

- Plant root uptake of contaminants and translocation to aboveground plant tissues. Aboveground plant tissues are assumed to senesce and be deposited in surface soil.

- Water well drilling occurring when residences are randomly located within the Area 5 RWMS.

Radionuclides are assumed to be immediately available for release and transport. Contaminants dissolved in the liquid phase are assumed to reversibly absorb on alluvium as described by an absorption coefficient, $K_{d}$, and to dissolve and precipitate as described by a solubility constant, $K_{s p}$. GoldSim handles all radioactive decay and ingrowth occurring during transport. 
Contaminants released to the land surface are assumed to be resuspended to the atmosphere and advected off site.

The closure cover is assumed to remain intact throughout the simulation for all cover thicknesses. Disposal unit subsidence is assumed to occur over time due to in-filling of voids, collapse of waste containers and waste forms, and compaction of backfill and waste. Subsidence is expected to occur in two phases: differential subsidence occurring early after closure as containers collapse, and areal subsidence occurring gradually over a longer time period (U.S. Department of Energy, Nevada Operations Office [DOE/NV], 1998). Differential subsidence may cause cracking or, in thinner cover designs, may expose buried waste. Differential subsidence is assumed to occur during the active institutional control period when the cover will be repaired and returned to its design specifications. Therefore, cover subsidence is assumed to have no effect on cover performance.

\subsubsection{Collective Dose Model}

Collective dose is the sum of all the individual total effective dose equivalents (TEDEs) received by all exposed persons over all time. The ICRP defines the collective effective dose equivalent, $S$, as (ICRP, 1991):

$$
S=\int_{o}^{\infty} E \frac{d N}{d E} d E
$$

where $E$ is the TEDE and $(d N / d E) d E$ is the number of individuals receiving an effective dose equivalent between $E$ and $E+d E$. In practice, the equation above is rarely used because calculation of the dose received by each individual is too complex (Smith et al., 2007). Collective dose is usually calculated as the summation of the mean dose rate in a population times the size of the population integrated over time or:

$$
S=\int_{0}^{\infty} \sum_{i=1}^{m} \dot{\bar{E}}_{i} N_{i} d t
$$

where $\dot{\bar{E}}_{i}$ is the mean TEDE rate in population $i$, and $N_{i}$ is the number of individuals in population $i$.

The mean dose rate is calculated as the annual TEDE rate for an adult with average living habits. The Area 5 RWMS PA model already includes methods to calculate the annual TEDE for several scenarios as the product of environmental media concentrations and a pathway dose conversion factor (PDCF). The residential exposure scenario is considered the most consistent with expected exposure conditions for an average homestead or community resident. The mean dose to drillers is also calculated when an onsite well occurs. The collective dose is calculated using the resident and acute driller PDCFs included in the Area 5 RWMS PA model.

The model disaggregates the exposed population into sub-groups exposed to similar environmental media concentrations. Populations engaged in similar activities at similar locations are expected to receive reasonably homogenous doses. For the Jackass Flats scenario, 
collective dose is calculated for onsite water well drillers, onsite homestead residents, offsite homestead residents in Frenchman Flat, and offsite community residents in Jackass Flats or Mercury. The base case community (or Frenchman Flat community) sub-groups are onsite water well drillers, onsite community residents, and offsite community residents.

\subsubsection{Cover Construction Cost Model}

Cover cost estimates were prepared for a 2.5- and 3.0-m closure cover for the 92-ac LLWMU. The ALARA optimization requires a cost estimate for the Northern Expansion Area and a method to scale cover construction costs with cover thickness. A model that estimates closure construction costs based on cover thickness and area is developed from the two cost estimates for the 92-ac LLWMU closure cover. Because only two cost estimates are available, the model assumes costs scale linearly with cover thickness and area.

The cover cost model was developed by extracting direct cost rates, indirect cost rates, labor rates, the fixed fee rate, the cost escalation rate, and the contingency rate from the estimates. Costs are scaled from two basic project dimensions: cover thickness and foot print. From these dimensions, three additional project dimensions, cover soil volume $\left(\mathrm{m}^{3}\right)$, perimeter $(\mathrm{m})$, and project duration (hours), are estimated from the cost data.

Direct costs were divided into fixed costs (mobilization/demobilization, construction support facilities, electrical preparation) and costs that scale with cover volume (earthwork, heavy equipment), cover perimeter (fencing), and cover area (grading, drainage, and revegation).

Indirect rates are incorporated in the model and were assigned subjective pdfs. Indirect costs scale with the product of a labor rate and project hours.

The total direct and indirect costs are escalated to the assumed dates of construction, which are 2011 for the 92-ac LLWMU and 2028 for the Northern Expansion Area. A contingency is added to the cost that is a stochastic fraction of the total costs.

\subsubsection{Cost-Benefit Analysis}

One of the components of the ICRP's dose limitation system, and a DOE M 435.1-1 requirement, is that individual doses, the number of individuals exposed, and the likelihood of exposure be ALARA, considering economic and social factors.

The optimization implements the quantitative cost-benefit optimization component of ALARA requirements. The goal of cost-benefit analysis is to select the option with the maximum net benefit, $B$, defined as:

$$
B=V-(P+X+Y)
$$

where $V$ is the gross benefit, $P$ is the production costs excluding radiation protection, $X$ is the cost of radiation protection, and $Y$ is the health detriment cost. Assuming the monetary value of the health detriment is constant,

$$
Y=\alpha S
$$


where $\alpha$ is the monetary value assigned to a unit of collective dose, $S$.

Optimization occurs when the maximum net benefit, $B$, is achieved. If the goal is to optimize the practice with respect to the level of radiation protection, then the optimum occurs where the derivative of $B$ with respect to $S$ equals 0 or:

$$
\frac{d V}{d S}-\frac{d P}{d S}-\frac{d X}{d S}-\frac{d Y}{d S}=0
$$

For the case of optimizing cover thickness at the Area 5 RWMS, the gross benefit and production costs, excluding radiation protection, appear to be independent of the collective dose.

In this case, the derivatives of gross benefit and production with respect to collective dose are zero. Setting the derivatives to zero and multiplying by zero, the above relationship simplifies to:

$$
\frac{d X}{d S}+\frac{d Y}{d S}=0
$$

The expression above indicates that the optimum level of protection occurs at the minimum total closure cost.

For the present case where cover thickness is being optimized, a finite range of cover thicknesses is considered. Three generalized cases can be imagined (Figure 2.1). In region I, $Y>>X$, the total cost is decreasing throughout the region, and the optimum thickness occurs at the maximum cover thickness. For region II, $Y$ and $X$ are of similar magnitude, and the optimum thickness occurs at an intermediate thickness where the minimum total cost occurs. In the final and third region where $Y<<X$, the total cost is monotonically increasing, and the optimum thickness is the thinnest cover evaluated.

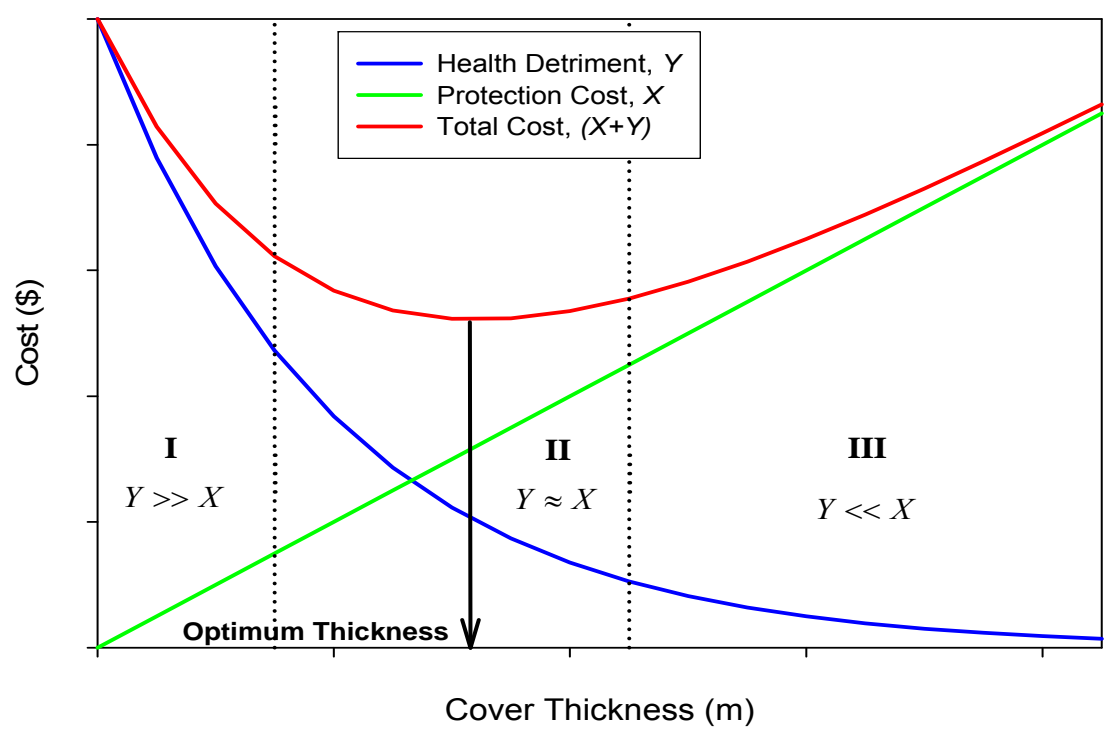

Figure 2.1 Conceptual diagram of cost-benefit process 


\subsubsection{Discounting}

The cover construction and health detriment costs considered in the cost-benefit analysis occur at different times and must be adjusted to account for the changing value of money. The optimization values benefits and costs at the expected date of final closure in 2028. Costs occurring before 2028 (i.e., construction costs of the 92-ac LLWMU and the Northern Expansion Area [in 2008 dollars] and the monetary value of health detriment [in 1990 dollars]) are escalated. The construction costs and health detriment costs are escalated assuming the escalation rate $\gamma \sim \mathrm{N}\left(0.038,0.005^{2}\right)$. The assumed distribution is the distribution of the mean annual inflation rate from 1950 to 2007.

Costs or benefits occurring after 2028 must be discounted. The collective dose is the only future cost and will occur over a much longer period than the cover construction costs. The farther into the future costs occur, the lower their present values. Application of conventional discounting methods to health detriment occurring in the distant future results in an infinitesimal present value that encourages shifting risks to future generations. This seems to contradict waste management regulations that value risks to future generations by requiring compliance thousands of years into the future (French et al., 2005). Alternatively, not discounting future health detriment introduces intergeneration inequity, as greater weight is applied to the risk to future generations at the expense of the present generation. Discounting is a complex issue for radioactive waste management optimizations. No consensus exists on how to select a discount rate, and it can be argued that there is no true or correct rate (Hanley, 1992). This indicates that the discount rate is another value parameter, as its selection reflects the subjective view of the decision maker about the value of future benefits and costs.

The optimization addresses value parameters by assigning discrete values that represent the opinions of different stakeholders. Reasonable values to consider for the discount rate are zero and non-zero values in the range of 0.02 to 0.10 . The exponential form of discounting and the long period over which collective dose is accrued ensures that any positive discount rate reduces the value of the health detriment to trivial levels. For example, assuming a low discount rate of 0.02 reduces the cost of future dose by an order of magnitude in 100 years. Because the collective dose occurs in the distant future, any non-zero discount rate effectively removes the health detriment from the cost-benefit analysis, and the total closure cost model simplifies to the construction cost model. In this case, the optimum cover is the least expensive to construct or the thinnest cover.

The optimization assumes a zero discount rate. This overestimates the cost of the health detriment, and will tend to shift the optimum cover thickness to thicker values. If the optimization indicates that the optimum cover thickness is the thinnest cover, there is no need to consider a positive discount rate, as it would only produce the same result.

\subsubsection{Individual Protection}

In recent years, ICRP has indicated that it plans to revise its recommendations and broaden the ALARA optimization process (Clarke, 2001; ICRP, 2005; ICRP, 2007a). A proposed change is to acknowledge that in addition to societal risk there is also individual risk. Collective dose assesses societal risks, but can mask inequities arising from differences in dose among individuals or distributions of dose in time and space. Because collective dose is summed over all individuals, large individual doses can be masked or diluted by a large number of individuals with low doses. 
The concept of individual protection has been introduced to address concerns about individual risk. Under the individual protection concept, single practices would be subject to an individual dose constraint with a requirement to reduce individual doses as low as reasonably practicable (ALARP) (Clarke, 2001). The ICRP has included this concept in its most recent recommendations by requiring that optimization be constrained by an individual dose limit (ICRP, 2005; ICRP 2007a). A constraint for single practices of $0.3 \mathrm{mSv}$ has been suggested (Clarke, 2001). A trivial dose (or de minimus dose), below which it is not practicable to reduce dose, has been suggested to be $0.03 \mathrm{mSv}$.

The DOE M 435.1-1 performance objective dose limits are similar to the dose constraint recommended by ICRP, providing some assurance that individual risk is constrained. However, differences exist between PA dose calculations, which assume residents are always present at the $100-\mathrm{m}$ (330-ft) site boundary, and collective dose calculations, which assume future residents are located stochastically in time and space. Recognizing that collective dose can mask inequities in individual doses, the optimization will confirm that individual doses composing the collective dose are a small fraction of background exposure rates.

\subsubsection{Sources and Treatment of Uncertainty}

Multiple sources of uncertainty contribute to uncertainty in the optimum cover thickness for closure of the Area 5 RWMS. Identification of sources or types of uncertainty inevitably leads to some sort of uncertainty classification system. Unfortunately, all such systems eventually prove to be unsatisfactory in their ability to clearly resolve uncertainty into the proposed categories (Morgan and Henrion, 1990; de Rocquigny et al., 2008). Important sources of uncertainty in the cover optimization include the following:

- Lack of understanding about the behavior of the physical, chemical, and biological components of the environment

- Lack of knowledge about the features, events, and processes operating in the system

- Lack of knowledge about the value of parameters describing the system due to lack of data, measurement errors, sampling errors, use of surrogate data, or other factors

- Uncertainty due to spatial, temporal, or individual variability over the system domain

The first three sources of uncertainty are theoretically reducible with additional study and data collection. The last source of uncertainty is a natural property of the system and is irreducible.

Following the convention typically observed in PAs, the optimization does not address the first two sources of uncertainty listed above. The results of the optimization are conditional on the features, events, and processes assumed to be operating; the system model used; and the assumed exposure scenario conditions.

Treatment of the reducible and irreducible parameter uncertainty should consider whether the assessment endpoint is a fixed value or a stochastic variable (NCRP, 1996; U.S. Environmental Protection Agency, 1997). The optimization's endpoint is a single fixed value (i.e., the optimum cover thickness of the Area $5 \mathrm{RWMS}$ ) with uncertainty resulting from lack of knowledge. Following the approach of the Area 5 RWMS PA, uncertainty arising from lack of knowledge is included in parameter uncertainty, but uncertainty due to spatial, temporal, or individual variability is averaged over the model domain. 
The PA portion of the model, which includes the inventory, the release and transport, and the dose assessment sub-models, removes variability from the analysis by selecting parameter pdfs that represent uncertainty in the mean value averaged over time, space, or population. The collective dose and construction cost sub-models use the same approach for most parameters including the characteristics and living habits of the exposed population. However, the simulation of future settlement in the collective dose model includes sources of temporal and spatial variability including the time of appearance, duration, location, and size of settlements. The collective dose sub-model co-mingles uncertainty and these noted sources of variability in the interest of simplicity and transparency. The disadvantage of co-mingling variability and uncertainty is that the variance of the collective dose is inflated with an irreducible component. The advantage is a much simpler model that is easier to document and explain. This compromise is acceptable as long as the variance of collective dose is acceptable and any attempt to reduce collective dose uncertainty recognizes that an irreducible component (i.e., variability) is present.

\subsubsection{Summary of Important Assumptions}

Important assumptions made to form the conceptual model are summarized below.

Release and Transport

- Radionuclides are assumed to be immediately available for release and transport.

- All transport pathways are upwards to the land surface. No groundwater pathway exists.

- Disposal unit subsidence has no effect on radionuclide release and transport.

Future Settlement

- The SMEs' opinions concerning settlement at the Area 5 RWMS over the next 10,000 years can be scaled linearly to a 1,000 year period.

- All Frenchman Flat homesteads associated with a community in Jackass Flats or Mercury appear and disappear simultaneously with the community.

- The activity of drill cuttings is the area weighted average over all disposal units.

- Radioactivity in drill cuttings decays after exhumation, but transport of exhumed radioactivity is assumed to cease after intrusion. Exhumed activity remains permanently in the surface soil. Undisturbed radioactivity in the disposal system continues to be transported.

- All primary wells and replacement wells are drilled simultaneously at the time of settlement.

- Each homestead is assumed to have one primary well. Communities are assumed to have four primary wells.

Collective Dose

- Offsite environmental media are contaminated by atmospheric transport only.

- Collective dose is truncated at 1,000 years.

- Collective dose is calculated for future populations living in Frenchman Flat, Jackass Flats, and Mercury only. 
- Collective dose is calculated using individual doses calculated for onsite drillers and adults with average living habits exposed in a residential exposure scenario.

- Population sizes are assumed to be constant during a community's lifetime.

- Institutional controls are assumed to eliminate exposure of onsite drillers and onsite residents as long as controls are effective.

- Contamination exhumed by drilling one well is assumed to be distributed over one 2,500 square meter $\left(\mathrm{m}^{2}\right)\left(27,000\right.$ square feet $\left.\left[\mathrm{ft}^{2}\right]\right)$ home lot.

Cost-Benefit Analysis

- The monetary value of health detriment, valued in 1990 dollars, is escalated to 2028, the date of final closure.

- Cover construction costs, valued in 2008 dollars, are escalated to the date of expenditure, FY 2011 for the 92-ac LLWMU and FY 2028 for the Northern Expansion Area.

- The monetary value of future (i.e., beyond closure in 2028) health detriment is not discounted.

\subsection{MODEL IMPLEMENTATION}

\subsubsection{Inventory Model}

The inventories used in the optimization are estimated probabilistically using the Area 5 Inventory GoldSim model, version 2.104. This version uses inventory records updated through the end of FY 2008. The model is modified to estimate the 92-ac LLWMU inventory and Northern Expansion Area inventory. The estimated inventories are summarized in Appendix A1.

\subsubsection{Settlement of Frenchman Flat}

Settlement by future residents is simulated in GoldSim as Poisson processes using timed event elements. Events simulated as a Poisson process occur randomly in time with rate $\alpha, \mathrm{yr}^{-1}$. Probability density functions for settlement rates, $\alpha$, for the Jackass Flats scenario and Frenchman Flat community scenario were estimated using the opinions elicited from the SMEs and the methods of Black et al. (2001).

The rate parameter for the Jackass Flats scenario was estimated by first selecting the number of years over 10,000 years a community would be present from a uniform distribution ranging from 2,500 to 7,500 years. The community lifetime distribution was then sampled repeatedly until the sum of the community lifetimes exceeded the time communities were assumed to be present. The number of samples drawn from the community lifetime distribution represents the number of settlement events. This process was repeated 10,000 times, and the number of settlement events was recorded for each fixed time interval simulation. The rate parameter is estimated as the number of settlement events divided by the fixed time interval, 10,000 years. The distribution of the rate parameter was fit by a four parameter beta distribution with mean $6.61 \times 10^{-3} \mathrm{yr}^{-1}$, standard deviation $2.17 \times 10^{-3} \mathrm{yr}^{-1}$, and range from $8 \times 10^{-4}$ to $1.4 \times 10^{-2} \mathrm{yr}^{-1}$. The mean Jackass Flats community recurrence interval, $\alpha^{-1}$, is 151 years. 
Once a settlement event occurs, the steps in Figure 2.2 are initiated to track the quantities required to calculate the collective dose. For populations on the Area $5 \mathrm{RWMS}$, the calculated quantity is the number of residents in the population. The quantity calculated for offsite populations is the population weighted long-term dispersion coefficient. These quantities are calculated in looping containers that are triggered by the occurrence of a settlement event. The quantities are tracked in time by reservoir elements.

Simulate Jackass Flats community settlement as Poisson process with parameter $\alpha \sim B\left(6.61 E-3 y r^{-1},(2.169 E-3)^{2} y r^{-2}, 0.0008 y r^{-1}, 0.014 y r^{-1}\right)$

Select remote community site: Jackass Flats $(p=0.5)$ or Mercury $(p=0.5)$

Sample community lifetime,

$L_{c} \sim$\begin{tabular}{c|cccccc}
$y r s$ & 10 & 35 & 50 & 65 & 100 & 600 \\
\hline$\Sigma p$ & 0.1 & 0.25 & 0.5 & 0.75 & 0.9 & 1
\end{tabular}

Sample community area, $A_{c} \sim U(160$ ac, 1,000 ac)

Sample lot size, $A_{L} \sim T(0.125 a c, 0.5 a c, 2 a c)$

Calculate number of community households, $H_{C}=\operatorname{round}\left(A_{d} / A_{L}\right)$

Loop once per household

\{

Sample number of residents per household,

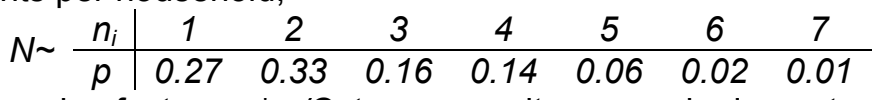

\}

Add person weighted dispersion factor, $n_{i}{ }^{*} X / Q$, to community reservoir element

Start delayed event element to remove $\Sigma n_{i}{ }^{*} X / Q$ from reservoir element at end of community lifetime, $L_{c}$

Sample number of homesteads in Frenchman Flat, $H_{h} \sim B\left(50,30^{2}, 0,200\right)$

Loop once per homestead

\{

Select random location in Frenchman Flat

Sample number of residents per homestead, N

Test if location is within the Area 5 RWMS

If homestead is on RWMS and institutional controls have failed then

\{

Sample well lifetime, $L_{w} \sim B\left(34.74 y r, 19.93^{2} y r^{2}, 0 y r, 220 y r\right)$

Calculate number of replacement wells, $W_{R}=\operatorname{ceil}\left(L_{d} L_{w}\right)-1$

Add borehole cuttings for primary and replacement wells to surface soil

Add residents, $\mathrm{n}_{\mathrm{i}}$, to on site resident reservoir element

\}

Else if homestead is off site then

\{

\}

Add $\left(n_{i}{ }^{*} X / Q_{i}\right)$ to offsite resident reservoir element

\}

Start delayed event elements to remove sums from reservoirs at end of community lifetime

End settlement event when community lifetime expires

$\mathrm{B}()$ - Beta distribution(mean, variance, lower limit, upper limit)

$\mathrm{U}()$ - Uniform distribution(lower limit, upper limit)

$\mathrm{T}()$ - Triangular distribution(lower limit, mode, upper limit)

$\mathrm{p}$ - probability

Figure 2.2 Algorithm for settlement of Frenchman Flat under the Jackass Flats scenario 
The source of the pdfs summarized in Figure 2.2 is the opinions of the SMEs recorded by Black et al. (2001). Exceptions are the community area, $A_{c}$, and lot size, $A_{L}$, which are from Addendum 1, Performance Assessment for the Area 5 Radioactive Waste Management Site at the Nevada Test Site, Nye County, Nevada, Revaluation of the Chronic Inadvertent Human Intrusion Scenarios to Resolve the Disposal Authorization Statement Issues (BN, 2001a).

The rate parameter for establishment of a community in Frenchman Flat was estimated by sampling the community lifetime distribution until the sum of lifetimes was at least 50 years. A minimum of one community was assumed for every simulation. This process was repeated 10,000 times, and the number of communities recorded for each simulation. The rate was estimated as the number of communities divided by 10,000 years.

The number of Frenchman Flat communities in 10,000 years ranged from one to five, with the vast majority of realizations having only one community. The probability of community settlement was estimated using a discrete distribution with the probability equal to the simulated frequency.

The algorithm in Figure 2.3 is initiated to track the quantities needed to calculate the collective dose for a Frenchman Flat community. For populations on the Area 5 RWMS, the calculated quantities are the number of persons in the population living on contaminated and uncontaminated home sites. The quantity calculated for offsite populations is the population weighted long-term atmospheric dispersion coefficient. Each quantity is calculated by a looping container that is triggered by the occurrence of a settlement event. The quantities are tracked in time by reservoir elements.

Once a community settlement event occurs, the community is located randomly in the habitable area of Frenchman Flat, and the location of the community relative to the RWMS is determined. There are three possible cases: (1) the community is completely within the RWMS, (2) the community partially overlaps the RWMS, and (3) the community is completely off site. If the community partially overlaps the RWMS, the overlapping area is calculated as the intersection of two circles as:

$$
\begin{aligned}
A_{c} \cap & A_{R W M S}=r^{2} \arccos \left(\frac{d^{2}+r^{2}-R^{2}}{2 d r}\right)+R^{2} \arccos \left(\frac{d^{2}+R^{2}-r^{2}}{2 d R}\right) \\
& -\frac{1}{2} \sqrt{(-d+r+R)(d+r-R)(d-r+R)(d+r+R)}
\end{aligned}
$$

where

$$
\begin{array}{lll}
A_{c} \cap A_{R W M S} & = & \text { area of community overlap, }\left(\mathrm{m}^{2}\right) \\
r & = & \text { radius of the RWMS, }(\mathrm{m}) \\
R & = & \text { radius of community }(\mathrm{m}) \\
d & = & \text { distance from center of RWMS to center of community }
\end{array}
$$

Onsite water well drilling is assumed to contaminate a limited area equal to $2,500 \mathrm{~m}^{2}$ per well drilled. Onsite community homes are divided into those in and outside of the contaminated areas created by well drilling. Contaminated home sites are filled first. Uncontaminated home sites only occur if the number of homes exceeds the number of contaminated home sites. 
Simulate Frenchman Flat community settlement event as Poisson process with parameter,

$$
\alpha \sim \quad \begin{array}{l|lllll}
\mathrm{x}_{\mathrm{i}}\left(\mathrm{yr}^{-1}\right) & 0.0001 & 0.0002 & 0.0003 & 0.0004 & 0.0005 \\
\hline p & 0.9047 & 0.0822 & 0.0117 & 0.0012 & 0.0002
\end{array}
$$

Sample community area, $A_{c} \sim U(160$ ac, 1,000 ac)

Sample lot size, $A_{L} \sim T(0.125$ ac, 0.5 ac, 2 ac)

Calculate number of community households, $H_{c}=\operatorname{round}\left(A_{d} / A_{L}\right)$

Select random location in Frenchman Flat

Test if location overlaps the Area 5 RWMS

If community overlaps the Area 5 RWMS and institutional controls have ended then \{

Calculate overlap area, $A_{c} \cap A_{R W M S}$

Calculate number of households on the Area 5 RWMS,

$H_{R W M S}=\operatorname{round}\left\{\left(A_{C} \cap A_{R W M S}\right) / A_{L}\right\}$

Randomly select the number of primary wells on the Area 5 RWMS,

$W_{p} \sim b\left\{n=4, p=\left(A_{c} \cap A_{R W M S}\right) / A_{c}\right\}$

Sample well lifetime, $L_{w} \sim B\left(34.74 y r, 19.93^{2} y^{2}, 0 y r, 220 y r\right)$

Calculate number of replacement wells, $W_{R}=$ ceil $\left(L_{d} L_{w}\right)-1$

Add borehole cuttings for primary and replacement wells to $W_{p}$ home sites. Loop once per contaminated on site home ( $W_{p}$ loops)

\{

Sample number of residents

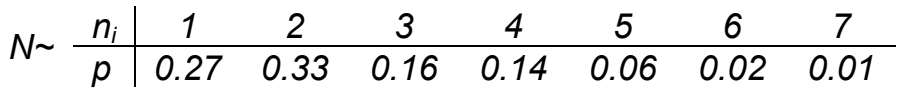

Add residents, $n_{i}$, to on site resident contaminated home reservoir element

\}

Loop once per uncontaminated on site home $\left(H_{R W M S}-W_{p}\right.$ loops $)$

\{

Sample number of residents, $\mathrm{N}$

Add residents, $n_{i}$, to on site resident uncontaminated home reservoir

\} element

\}

If there are off site homes $\left(H_{c}-H_{R W M S}>0\right)$ then

\{

Loop once per off site household $\left(H_{c}-H_{R W M S}\right.$ loops)

\{

Calculate distance from home to RWMS

Sample number of residents, $\mathrm{N}$

Add population weighted dispersion factor, $n_{i}{ }^{*} \times / Q$, to offsite resident

\} reservoir

\}

Start delayed event elements to remove residents and person weighted dispersion factors from reservoirs at end of community lifetime

End Frenchman Flat community settlement event

$b()-$ binomial distribution(number of trials, probability of success)

Figure 2.3 Algorithm for settlement of Frenchman Flat under the Frenchman Flat community scenario 
If a community overlaps the RWMS, the distance from the Area 5 RWMS to offsite homes is sampled from a uniform distribution with lower limit of $0 \mathrm{~m}$ and upper limit calculated as:

$$
x=R+d-r
$$

where $\mathrm{x}$ represents the maximum distance between a circular RWMS boundary and a circular community boundary. For completely offsite communities, the distance is the distance between the centers of the RWMS and the community.

\subsubsection{Location of Settlements}

Locations of homesteads and communities in Frenchman Flat are selected using identical procedures. The Jackass Flats scenario, however, requires multiple homestead sites for the appearance of each community. In this case multiple sites are selected by a looping container. The location of future settlements in Frenchman Flat is selected randomly from the habitable area. The habitable area is assumed to exclude mountain ranges and the playa. The habitable area of Frenchman Flat was modeled as 16, 22.5-degree sectors radiating from the center of the Area 5 RMWS (Table 2.1). The areas were mapped by estimating the mean length of each segment where the slope was judged too steep to support development. This break was judged to occur at an elevation of approximately $1,066 \mathrm{~m}(3,500) \mathrm{ft}$, except in the most eastern part of the basin, where the elevation was approximately $1,370 \mathrm{~m}(4,500 \mathrm{ft})$. Uninhabitable intervening sections, the Half-Pint Range in sectors 13 and 14 and the playa in sectors 6 and 7, were excluded. The total habitable model area is 86,074 ac, approximately equivalent to the 86,000 ac assumed in the simulations of Black et al. (2001).

Table 2.1 Geometric representation of the habitable area of Frenchman Flat

\begin{tabular}{|c|c|c|c|c|c|}
\hline Sector & $\begin{array}{c}\text { Start } \\
\text { (Degrees) }\end{array}$ & $\begin{array}{c}\text { End } \\
\text { (Degrees) }\end{array}$ & $\begin{array}{c}\text { Total Sector } \\
\text { Length }(\mathbf{m})\end{array}$ & $\begin{array}{c}\text { Range of } \\
\text { Uninhabitable } \\
\text { Segment }(\mathbf{m})\end{array}$ & Sector Area $\left(\mathbf{m}^{2}\right)$ \\
\hline 1 & 0 & 22.5 & 3909 & NA & $3.00 \mathrm{E}+06$ \\
\hline 2 & 22.5 & 45 & 7454 & NA & $1.09 \mathrm{E}+07$ \\
\hline 3 & 45 & 67.5 & 9364 & NA & $1.72 \mathrm{E}+07$ \\
\hline 4 & 67.5 & 90 & 9636 & NA & $1.82 \mathrm{E}+07$ \\
\hline 5 & 90 & 112.5 & 17182 & NA & $5.80 \mathrm{E}+07$ \\
\hline 6 & 112.5 & 135 & 10287 & NA & $2.08 \mathrm{E}+07$ \\
\hline 7 & 135 & 157.5 & 9909 & $5545-7909$ & $1.30 \mathrm{E}+07$ \\
\hline 8 & 157.5 & 180 & 16455 & $4909-8182$ & $4.47 \mathrm{E}+07$ \\
\hline 9 & 180 & 202.5 & 15273 & NA & $4.58 \mathrm{E}+07$ \\
\hline 10 & 202.5 & 225 & 13182 & NA & $3.41 \mathrm{E}+07$ \\
\hline 11 & 225 & 247.5 & 6909 & NA & $9.37 \mathrm{E}+06$ \\
\hline 12 & 247.5 & 270 & 11545 & NA & $2.62 \mathrm{E}+07$ \\
\hline 13 & 270 & 292.5 & 11000 & $2818-4545$ & $2.13 \mathrm{E}+07$ \\
\hline 14 & 292.5 & 315 & 11364 & $2727-5273$ & $2.14 \mathrm{E}+07$ \\
\hline 15 & 315 & 337.5 & 2909 & NA & $1.66 \mathrm{E}+06$ \\
\hline 16 & 337.5 & 360 & 3727 & NA & $2.73 \mathrm{E}+06$ \\
\hline Total & \multicolumn{5}{r}{} \\
\hline
\end{tabular}

NA - not applicable, no uninhabitable region present 
Selecting a random location begins by randomly sampling an angle between 0 and 360 degrees. The angle is sampled from a cumulative distribution where the probability of an angle falling in any sector is the area of that sector divided by the total model area. The radial distance from the RWMS is selected next as the fractional radial distance (i.e., distance from RWMS/total sector length). The fractional radial distance, $r$, is selected from a distribution where the cumulative distribution is the ratio of the area within that distance $\left(\pi \mathrm{r}^{2}\right)$ divided by the total sector area for a unit circle $\left(\pi 1^{2}\right)$, which is equal to $r^{2}$. The fractional radial distance is multiplied by the length of the sector to obtain the distance from the RWMS. Settlement sites are divided into onsite and offsite locations by comparing the settlement distance to the virtual radius of the Area 5 RWMS disposal units.

\subsubsection{Number of Residents}

Each homestead or community residence is assumed to have a stochastic number of residents. The number of residents remains constant throughout the community's lifetime. The number of residents per household was estimated from the 2004 U.S. Census American Community Survey. The probability was the observed frequency of the household size (Table 2.2).

Table 2.2 Assumed distribution for number of residents per household

\begin{tabular}{|c|c|}
\hline Probability & Household Size (persons) \\
\hline 0.2691 & 1 \\
\hline 0.3333 & 2 \\
\hline 0.1607 & 3 \\
\hline 0.1386 & 4 \\
\hline 0.06264 & 5 \\
\hline 0.02168 & 6 \\
\hline 0.01393 & 7 \\
\hline
\end{tabular}

\subsubsection{Release and Transport}

The release and transport model is implemented in GoldSim as a series of one-dimensional linked mixing cells. Links between the cells represent advective, diffusive, and direct mass transfers. The Area 5 RWMS is represented by four sets of mixing cells, each set representing a virtual disposal unit. The four virtual disposal units combine units with similar disposal geometry and are: the SLB disposal units, Pit 6 RaDU, Pit 13 RaDU, and GCD.

\subsubsection{Collective Dose}

Collective dose is calculated as the sum of collective dose over all sub-groups, integrated over time. The collective dose is calculated differently for drillers and residents. When a discrete settlement event occurs on the Area 5 RWMS, the driller collective dose is calculated as the sum over all exposure pathways of the product of the number of drillers, the PDCF, and the environmental media concentration. Driller collective dose is accumulated by discrete additions corresponding to intrusion events. Resident collective dose is calculated as a collective dose rate, continuously accumulated by an integrator element. The collective dose rate for onsite residents is calculated as the sum over all exposure pathways of the product of the number of residents, the PDCF, and the environmental media concentration. The collective dose rate for offsite residents 
is calculated as the sum over all exposure pathways of the product of the population-weighted long-term atmospheric dispersion factor, the PDCF, and the radionuclide release rates.

\subsubsection{Cost Benefit Analysis}

The cost benefit analysis is implemented externally to the Area 5 RWMS GoldSim model. The GoldSim model is used to generate a vector of random input variables and calculate the total closure cost for each of the five discrete cover thicknesses using the same input vector for each cover thickness (Figure 2.4). External to the GoldSim model, the relationship between total closure cost and cover thickness is evaluated to determine the cover thickness corresponding to the minimum total closure cost. This process is repeated 2,000 times to generate a distribution for the uncertainty in the optimum cover thickness.

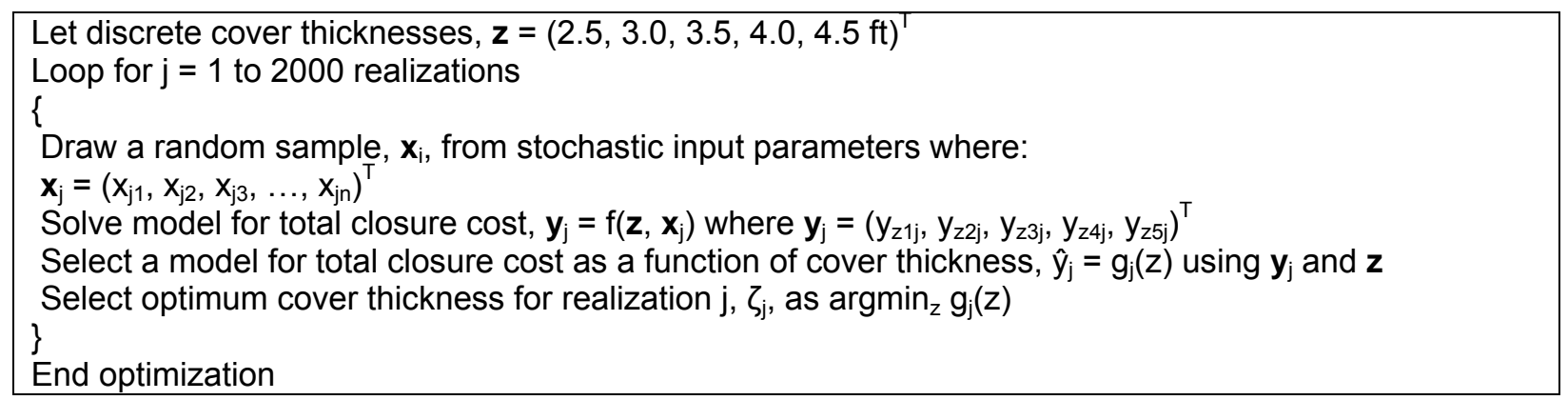

\section{Figure 2.4 Algorithm for optimization of cover thickness}

For almost every realization of $\mathbf{y}_{\mathbf{j}}$, visual inspection of the relationship between total closure cost and cover thickness indicated that total cost is a linearly increasing function of cover thickness. In this case, the optimum cover thickness is the minimum cover thickness evaluated. Numerical estimation of the function minimum is not necessary. 


\subsection{RESULTS}

The purpose of the ALARA analysis is to find the optimum cover thickness, which by definition is the cover thickness with the minimum total closure cost. The total closure cost is calculated as the sum of the monetary value of the collective dose and the cover construction costs. The optimization is constrained by the requirements that the options meet all applicable radiological requirements and that individual dose remains a small fraction of background dose. The optimization is performed probabilistically by generating 2,000 estimates of the optimum cover thickness.

\subsection{CONSTRAINTS}

\subsubsection{Compliance with Applicable Regulatory Requirements}

Five discrete cover thicknesses, $2.5,3.0,3.5,4.0$, and $4.5 \mathrm{~m}(8.2,9.8,11,13$, and $15 \mathrm{ft})$ are evaluated as closure options. The options considered must meet all applicable radiological regulatory requirements to be a candidate for an optimal ALARA cover. LLW disposed after 1988 is subject to the DOE M 435.1-1 PA performance objectives. The entire Area 5 RWMS inventory is subject to the DOE M 435.1-1 composite analysis dose constraint. TRU waste in the GCD boreholes is subject to the requirements of 40 CFR 191.

\subsubsection{92-ac LLWMU}

The post-1988 92-ac LLWMU inventory was evaluated for compliance with the PA performance objectives with a 2.5 and $4.0 \mathrm{~m}$ ( 8.2 to $13 \mathrm{ft})$ cover. The mean and median results were less than the performance objectives for the 2.5 - and $4.0-\mathrm{m}(8.2-$ to 13 -ft) covers for all scenarios (Table 3.1). Site performance improved or was unaffected by increasing cover thickness, depending on the scenario. The $95^{\text {th }}$ percentile results are less than the performance objectives for all scenarios except the acute construction scenario applied to the SLB inventory with a $2.5-\mathrm{m}(8.2-\mathrm{ft})$ cover. The acute construction scenario results are calculated assuming the probability is one that a basement will be constructed. Basements are rare in southern Nevada, occurring in 4 of 396 homes (BN, 2001a). Considering the low probability of a home being constructed on the Area 5 RWMS and low probability the home would have a basement, it is extremely unlikely that the estimated acute construction doses will ever be realized. 
Table 3.1 Performance assessment compliance evaluation for the post-1988 92-ac LLWMU inventory for a 2.5 - and $4.0-\mathrm{m}$ cover

\begin{tabular}{|c|c|c|c|c|c|c|}
\hline \multirow{2}{*}{$\begin{array}{l}\text { Performance } \\
\text { Objective }\end{array}$} & \multirow[b]{2}{*}{ Scenario } & \multirow[b]{2}{*}{ Limit } & \multicolumn{2}{|c|}{$2.5 \mathrm{~m}$ SLB Cover } & \multicolumn{2}{|c|}{$4.0 \mathrm{~m}$ SLB Cover } \\
\hline & & & Mean & $\begin{array}{c}95^{\text {th }} \\
\text { Percentile }\end{array}$ & Mean & $\begin{array}{c}95^{\text {th }} \\
\text { Percentile }\end{array}$ \\
\hline \multirow{5}{*}{ Air Pathway } & Transient Occupancy & \multirow{5}{*}{$0.1 \mathrm{mSv} \mathrm{yr}^{-1}$} & $1.8 \mathrm{E}-4$ & $7.2 \mathrm{E}-4$ & $2.5 \mathrm{E}-6$ & NA \\
\hline & Resident & & $5.0 \mathrm{E}-4$ & $2.0 \mathrm{E}-3$ & $2.2 \mathrm{E}-6$ & $5.4 \mathrm{E}-6$ \\
\hline & Resident Farmer & & $6.7 \mathrm{E}-4$ & $2.7 \mathrm{E}-3$ & $3.0 \mathrm{E}-6$ & $7.1 \mathrm{E}-6$ \\
\hline & Cane Springs & & $4.8 \mathrm{E}-9$ & $2.1 \mathrm{E}-8$ & $8.8 \mathrm{E}-10$ & NA \\
\hline & NTS Boundary & & $1.0 \mathrm{E}-7$ & $4.4 \mathrm{E}-7$ & $1.2 \mathrm{E}-8$ & NA \\
\hline \multirow{5}{*}{ All Pathways } & Transient Occupancy & \multirow{5}{*}{$0.25 \mathrm{mSv}_{\mathrm{yr}}{ }^{-1}$} & $3.2 \mathrm{E}-3$ & $7.5 \mathrm{E}-3$ & $8.9 \mathrm{E}-4$ & $2.1 \mathrm{E}-3$ \\
\hline & Resident & & $1.1 \mathrm{E}-3$ & $4.2 \mathrm{E}-3$ & $3.6 \mathrm{E}-5$ & NA \\
\hline & Resident Farmer & & $7.0 \mathrm{E}-3$ & NA & $3.4 \mathrm{E}-3$ & NA \\
\hline & Cane Springs & & $1.2 \mathrm{E}-3$ & NA & $5.7 \mathrm{E}-4$ & NA \\
\hline & NTS Boundary & & $1.3 \mathrm{E}-3$ & NA & $6.1 \mathrm{E}-4$ & NA \\
\hline${ }^{222}$ Rn Flux & & $0.74 \mathrm{~Bq} \mathrm{~m}^{-2} \mathrm{~s}^{-1}$ & 0.095 & 0.20 & 0.031 & 0.066 \\
\hline \multirow{6}{*}{$\begin{array}{l}\text { Intruder } \\
\text { Acute } \\
\text { Exposure }\end{array}$} & SLB Drilling & \multirow{6}{*}{$5 \mathrm{mSv}$} & $2.7 \mathrm{E}-3$ & $6.7 \mathrm{E}-3$ & $2.2 \mathrm{E}-3$ & $5.6 \mathrm{E}-3$ \\
\hline & Pit 6 Drilling & & 0.026 & 0.051 & 0.023 & 0.048 \\
\hline & GCD Drilling & & 0.014 & 0.039 & 0.013 & 0.037 \\
\hline & SLB Construction & & 3.7 & 9.6 & $3.9 \mathrm{E}-3$ & $9.1 \mathrm{E}-3$ \\
\hline & Pit 6 Construction & & 0.036 & 0.065 & $5.8 \mathrm{E}-3$ & 0.013 \\
\hline & GCD Construction & & $1.3 \mathrm{E}-6$ & NA & $6.2 \mathrm{E}-7$ & NA \\
\hline \multirow{6}{*}{$\begin{array}{l}\text { Intruder } \\
\text { Chronic } \\
\text { Exposure }\end{array}$} & SLB Postdrilling & \multirow{6}{*}{$1 \mathrm{mSv}$} & $4.2 \mathrm{E}-3$ & 0.012 & $4.2 \mathrm{E}-3$ & 0.012 \\
\hline & Pit 6 Postdrilling & & $7.1 \mathrm{E}-4$ & $1.8 \mathrm{E}-3$ & $7.1 \mathrm{E}-4$ & $1.8 \mathrm{E}-3$ \\
\hline & GCD Postdrilling & & $3.3 \mathrm{E}-7$ & $1.0 \mathrm{E}-6$ & $3.3 \mathrm{E}-7$ & $1.0 \mathrm{E}-6$ \\
\hline & SLB Intruder-Ag. & & 0.26 & 0.76 & 0.015 & 0.056 \\
\hline & Pit 6 Intruder-Ag. & & $7.3 \mathrm{E}-5$ & $1.7 \mathrm{E}-4$ & $1.1 \mathrm{E}-5$ & $3.1 \mathrm{E}-5$ \\
\hline & GCD Intruder-Ag. & & 1.7E-10 & NA & $8.4 \mathrm{E}-11$ & NA \\
\hline
\end{tabular}

$\mathrm{NA}$ - not available, insufficient non-zero realizations to compute $95^{\text {th }}$ percentile

\subsubsection{Northern Expansion Area}

The Northern Expansion Area including the future inventory estimate was evaluated for compliance with the PA performance objectives with a 2.5- and 4.0-m (8.2- to 13-ft) cover. The entire Northern Expansion Area inventory was disposed after 1988. The mean and median results were less than the performance objectives for the 2.5- and 4.0-m (8.2- to 13-ft) covers for all scenarios (Table 3.2). Site performance improved or was unaffected by increasing cover thickness, depending on the scenario. The $95^{\text {th }}$ percentile results are also less than the performance objectives, except for the intruder-agriculture scenario applied to the SLB inventory with a 2.5-m (8.2-ft) cover. The Northern Expansion Area inventory includes future inventory, which is significantly more uncertain than disposed inventory, especially for rare radionuclides that are disposed sporadically at widely different concentrations. This greater uncertainty contributes to the higher $95^{\text {th }}$ percentile. All of the cover options are acceptable options for the Northern Expansion Area with respect to the applicable regulatory requirements. 
Table 3.2 Performance assessment compliance evaluation for the Northern Expansion Area inventory for a 2.5 - and $4.0-\mathrm{m}$ cover

\begin{tabular}{|c|c|c|c|c|c|c|}
\hline \multirow{2}{*}{$\begin{array}{l}\text { Performance } \\
\text { Objective }\end{array}$} & \multirow[b]{2}{*}{ Scenario } & \multirow[b]{2}{*}{ Limit } & \multicolumn{2}{|c|}{$2.5 \mathrm{~m}$ SLB Cover } & \multicolumn{2}{|c|}{$4.0 \mathrm{~m}$ SLB Cover } \\
\hline & & & Mean & $\begin{array}{c}95^{\text {th }} \\
\text { Percentile }\end{array}$ & Mean & $\begin{array}{c}95^{\text {th }} \\
\text { Percentile }\end{array}$ \\
\hline \multirow{5}{*}{ Air Pathway } & Transient Occupancy & \multirow{5}{*}{$0.1 \mathrm{mSv}_{\mathrm{yr}}{ }^{-1}$} & $1.4 \mathrm{E}-4$ & $3.0 \mathrm{E}-4$ & $3.4 \mathrm{E}-6$ & NA \\
\hline & Resident & & $3.8 \mathrm{E}-4$ & $8.4 \mathrm{E}-4$ & $2.1 \mathrm{E}-6$ & $5.0 \mathrm{E}-6$ \\
\hline & Resident Farmer & & $5.0 \mathrm{E}-4$ & $1.2 \mathrm{E}-3$ & $2.7 \mathrm{E}-6$ & $6.8 \mathrm{E}-6$ \\
\hline & Cane Springs & & $6.0 \mathrm{E}-9$ & $1.4 \mathrm{E}-8$ & $1.5 \mathrm{E}-9$ & NA \\
\hline & NTS Boundary & & $1.3 \mathrm{E}-7$ & $3.1 \mathrm{E}-7$ & $2.1 \mathrm{E}-8$ & NA \\
\hline \multirow{5}{*}{ All Pathways } & Transient Occupancy & \multirow{5}{*}{$0.25 \mathrm{mSv}_{\mathrm{yr}}{ }^{-1}$} & $3.8 \mathrm{E}-3$ & $7.5 \mathrm{E}-3$ & $8.2 \mathrm{E}-4$ & $2.0 \mathrm{E}-3$ \\
\hline & Resident & & $2.7 \mathrm{E}-3$ & 7.0E-3 & $3.5 \mathrm{E}-5$ & $9.0 \mathrm{E}-5$ \\
\hline & Resident Farmer & & 0.015 & 0.048 & $4.5 \mathrm{E}-3$ & NA \\
\hline & Cane Springs & & $1.2 \mathrm{E}-3$ & NA & $5.7 \mathrm{E}-4$ & NA \\
\hline & NTS Boundary & & $1.5 \mathrm{E}-3$ & NA & $6.6 \mathrm{E}-4$ & NA \\
\hline${ }^{222}$ Rn Flux & & $0.74 \mathrm{~Bq} \mathrm{~m}^{-2} \mathrm{~s}^{-1}$ & 0.090 & 0.20 & 0.029 & 0.064 \\
\hline \multirow{4}{*}{$\begin{array}{l}\text { Intruder } \\
\text { Acute } \\
\text { Exposure }\end{array}$} & SLB Drilling & \multirow{4}{*}{$5 \mathrm{mSv}$} & 3.7E-3 & $3.6 \mathrm{E}-3$ & 3.3E-3 & $2.9 \mathrm{E}-3$ \\
\hline & Pit 13 RaDU Drilling & & 0.026 & 0.035 & 0.025 & 0.032 \\
\hline & SLB Construction & & 3.4 & 4.0 & $2.9 \mathrm{E}-3$ & $6.9 \mathrm{E}-3$ \\
\hline & Pit 13 RaDU Construction & & 0.066 & 0.22 & 0.021 & 0.072 \\
\hline \multirow{4}{*}{$\begin{array}{l}\text { Intruder } \\
\text { Chronic } \\
\text { Exposure }\end{array}$} & SLB Postdrilling & \multirow{4}{*}{$1 \mathrm{mSv}$} & $7.1 \mathrm{E}-3$ & 0.016 & $7.1 \mathrm{E}-3$ & 0.016 \\
\hline & Pit 13 RaDU Postdrilling & & $1.3 \mathrm{E}-3$ & $2.9 \mathrm{E}-3$ & $1.3 e-3$ & $2.9 \mathrm{E}-3$ \\
\hline & SLB Intruder-Ag. & & 0.40 & 1.4 & 0.073 & 0.31 \\
\hline & Pit 13 RaDU Intruder-Ag. & & $7.9 \mathrm{E}-4$ & $2.8 \mathrm{E}-3$ & $2.4 \mathrm{E}-4$ & 8.7E-4 \\
\hline
\end{tabular}

NA - Not available, insufficient non-zero realizations to calculate $95^{\text {th }}$ percentile

Compliance evaluations for the TRU in GCD boreholes under 40 CFR 191 were not performed. The 40 CFR 191 GCD PA was performed with a cover thickness that corresponds to a 3.2-m (10.5-ft) SLB cover (Cochran et al., 2001). A 3.2-m (10.5-ft) cover is slightly thicker than the minimum cover evaluated in the optimization, $2.5 \mathrm{~m}(8.2 \mathrm{ft})$. The difference represents only 3 percent of the total GCD cover thickness. It is unlikely that the true depth of burial of GCD waste is known with this precision. Given this insignificant difference and the ease with which the GCD boreholes meet the 40 CFR 191 requirements, it is assumed that all of the options are also very likely to comply for the GCD boreholes. All of the cover options comply with the applicable radiological requirements for the 92-ac LLWMU.

\subsubsection{Area 5 RWMS}

The entire post-1988 Area 5 RWMS closure inventory including the future inventory estimate was evaluated for compliance with the PA performance objectives with a 2.5 - and $4.0-\mathrm{m}$ (8.2- and 13-ft) cover. The mean and median results were less than the performance objectives for the 2.5- and 4.0-m (8.2- and 13-ft) covers for all scenarios (Table 3.3). Site performance improved or was unaffected by increasing cover thickness. The Area 5 RWMS inventory includes the 92-ac LLWMU and Northern Expansion Area, and as expected the same $95^{\text {th }}$ percentile results for the acute construction and intruder-agriculture scenarios exceed the performance objectives. 
Table 3.3 Performance assessment compliance evaluation for the entire Area 5 RWMS post-1988 inventory at closure for a 2.5- and 4.0-m cover

\begin{tabular}{|c|c|c|c|c|c|c|}
\hline \multirow{2}{*}{$\begin{array}{l}\text { Performance } \\
\text { Objective }\end{array}$} & \multirow[b]{2}{*}{ Scenario } & \multirow[b]{2}{*}{ Limit } & \multicolumn{2}{|c|}{$2.5 \mathrm{~m}$} & \multicolumn{2}{|c|}{$4.0 \mathrm{~m}$} \\
\hline & & & Mean & $\begin{array}{c}95^{\text {th }} \\
\text { Percentile }\end{array}$ & Mean & $\begin{array}{c}95^{\text {th }} \\
\text { Percentile }\end{array}$ \\
\hline \multirow{5}{*}{ Air Pathway } & Transient Occupancy & \multirow{5}{*}{$0.1 \mathrm{mSv} \mathrm{yr}^{-1}$} & $1.5 \mathrm{E}-4$ & $4.4 \mathrm{E}-4$ & $4.2 \mathrm{E}-6$ & NA \\
\hline & Resident & & $4.2 \mathrm{E}-4$ & $1.2 \mathrm{E}-3$ & $2.1 \mathrm{E}-6$ & $4.7 \mathrm{E}-6$ \\
\hline & Resident Farmer & & $5.6 e-4$ & $1.6 e-4$ & $2.8 \mathrm{E}-6$ & $6.4 \mathrm{E}-6$ \\
\hline & Cane Springs & & $1.1 \mathrm{e}-8$ & $3.5 e-8$ & $2.4 \mathrm{E}-9$ & NA \\
\hline & NTS Boundary & & $2.3 e-7$ & $7.6 \mathrm{e}-7$ & $3.3 \mathrm{E}-8$ & NA \\
\hline \multirow{5}{*}{ All Pathways } & Transient Occupancy & \multirow{5}{*}{$0.25 \mathrm{mSv} \mathrm{yr}^{-1}$} & $3.6 e-3$ & $6.7 e-3$ & $8.4 \mathrm{E}-4$ & $1.9 \mathrm{E}-3$ \\
\hline & Resident & & $2.1 \mathrm{e}-3$ & $3.4 \mathrm{e}-3$ & $3.5 \mathrm{E}-5$ & $8.5 E-5$ \\
\hline & Resident Farmer & & 0.011 & 0.037 & $4.2 \mathrm{E}-3$ & NA \\
\hline & Cane Springs & & $1.2 \mathrm{e}-3$ & NA & $5.8 \mathrm{E}-4$ & NA \\
\hline & NTS Boundary & & $1.7 \mathrm{e}-3$ & NA & $7.2 \mathrm{E}-4$ & NA \\
\hline${ }^{222}$ Rn Flux & & $0.74 \mathrm{~Bq} \mathrm{~m}^{-2} \mathrm{~s}^{-1}$ & 0.091 & 0.18 & 0.029 & 0.059 \\
\hline \multirow{8}{*}{$\begin{array}{l}\text { Intruder } \\
\text { Acute } \\
\text { Exposure }\end{array}$} & SLB Drilling & \multirow{8}{*}{$5 \mathrm{mSv}$} & 3.3E-3 & $4.3 E-3$ & $2.9 \mathrm{E}-3$ & $3.6 \mathrm{E}-3$ \\
\hline & Pit 6 Drilling & & 0.028 & 0.054 & 0.024 & 0.049 \\
\hline & Pit 13 RaDU Drilling & & 0.026 & 0.035 & 0.025 & 0.032 \\
\hline & GCD Drilling & & 0.014 & 0.039 & 0.013 & 0.037 \\
\hline & SLB Construction & & 3.4 & 5.3 & $3.2 \mathrm{E}-3$ & $7.2 \mathrm{E}-3$ \\
\hline & Pit 6 Construction & & 0.044 & 0.081 & 8.3E-3 & 0.018 \\
\hline & Pit 13 RaDU Construction & & 0.066 & 0.22 & 0.021 & 0.072 \\
\hline & GCD Construction & & $2.2 \mathrm{E}-6$ & NA & $1.0 \mathrm{E}-6$ & NA \\
\hline \multirow{8}{*}{$\begin{array}{l}\text { Intruder } \\
\text { Chronic } \\
\text { Exposure }\end{array}$} & SLB Postdrilling & \multirow{8}{*}{$1 \mathrm{mSv}$} & $5.4 \mathrm{E}-3$ & 0.017 & $5.4 \mathrm{E}-3$ & 0.017 \\
\hline & Pit 6 Postdrilling & & $7.1 \mathrm{E}-4$ & $1.8 \mathrm{E}-3$ & $7.1 \mathrm{E}-4$ & $1.8 \mathrm{E}-3$ \\
\hline & Pit 13 RaDU Postdrilling & & $1.3 \mathrm{E}-3$ & $2.9 \mathrm{E}-3$ & $1.3 \mathrm{E}-4$ & $2.9 \mathrm{E}-3$ \\
\hline & GCD Postdrilling & & $3.3 \mathrm{E}-7$ & $1.0 \mathrm{E}-6$ & $3.3 \mathrm{E}-7$ & $1.0 \mathrm{E}-6$ \\
\hline & SLB Intruder-Ag. & & 0.36 & 1.2 & 0.053 & 0.22 \\
\hline & Pit 6 Intruder-Ag. & & $7.3 \mathrm{E}-5$ & 1.7E-5 & $1.1 \mathrm{E}-5$ & $3.1 \mathrm{E}-5$ \\
\hline & Pit 13 RaDU Intruder-Ag. & & $7.9 \mathrm{E}-4$ & $2.8 \mathrm{E}-3$ & $2.4 \mathrm{E}-4$ & $8.7 \mathrm{E}-4$ \\
\hline & GCD Intruder-Ag. & & $2.9 \mathrm{E}-10$ & NA & $1.4 \mathrm{E}-10$ & NA \\
\hline
\end{tabular}

NA - Not available, insufficient non-zero realizations to calculate $95^{\text {th }}$ percentile

The entire Area 5 RWMS closure inventory including the pre-1988 and future waste inventory was also evaluated for compliance with the CA dose constraint with a 2.5- and 4.0-m (8.2- and $13-\mathrm{ft})$ cover. The mean and median results for the Area $5 \mathrm{RWMS}$ were less than the $0.3 \mathrm{mSv}$ dose constraint for the 2.5- and 4.0-m (8.2- and 13-ft) covers for all scenarios (Table 3.4). The $95^{\text {th }}$ percentile results were also less than the dose constraint. Results from the current Area 5 RWMS CA indicate that the annual dose from all interacting sources of residual contamination at the site is approximately $5 \mathrm{E}-4 \mathrm{mSv}(\mathrm{BN}, 2001 \mathrm{~b})$. The combined annual TEDE from the Area 5 RWMS and all interacting sources is significantly less than the $0.3 \mathrm{mSv}$ CA dose constraint. 
Table 3.4 Composite analysis evaluation for the entire Area 5 RWMS inventory at closure for a 2.5- and 4.0-m cover

\begin{tabular}{|c|c|c|c|c|c|c|}
\hline \multirow{2}{*}{ Performance Objective } & Scenario & Limit & \multicolumn{2}{|c|}{$2.5 \mathrm{~m}$} & \multicolumn{2}{|c|}{$4.0 \mathrm{~m}$} \\
\cline { 4 - 7 } & & & Mean & $\begin{array}{c}95^{\text {th }} \\
\text { Percentile }\end{array}$ & Mean & $\begin{array}{c}95^{\text {th }} \\
\text { Percentile }\end{array}$ \\
\hline Composite Analysis & Resident & $0.3 \mathrm{mSv}$ & $2.1 \mathrm{E}-3$ & $4.0 \mathrm{E}-3$ & $1.1 \mathrm{E}-4$ & $3.4 \mathrm{E}-4$ \\
\hline
\end{tabular}

The cover thickness options considered, 2.5 to $4.5 \mathrm{~m}$ ( 8.2 to $15 \mathrm{ft})$, meet all applicable radiological regulations for the 92-ac LLWMU, Northern Expansion Area, and the entire Area 5 RWMS.

\subsubsection{Individual Dose}

Collective dose, because it is summed over all individuals, can mask the magnitude of individual doses. To ensure that individual doses are not excessive, ICRP has recommended that individual dose be constrained during ALARA optimization. The present optimization has adopted a constraint that individual dose be a small fraction of background doses. In addition, the decision to limit the spatial boundaries of the assessment to Frenchman Flat and Jackass Flats was based on the assumption that doses beyond these areas would be at de minimus levels. Individual dose can also be used to test this assumption.

Individual dose was evaluated by examining the distribution of the maximum individual doses occurring in each realization, where maximum refers to the maximum dose observed over a 1,000-year simulation and individual dose is the TEDE for an average adult. The groups expected to have the largest individual doses are onsite residents and onsite drillers. The magnitude of the maximum individual dose was evaluating by plotting the empirical cumulative distribution function (ecdf) for the groups with highest expected exposures (Figure 3.1). The ecdf of the maximum onsite homesteader annual TEDE, which expresses uncertainty in this quantity, indicates that there is a high probability that the maximum individual doses are less than 10 percent of the annual TEDE from background radiation, or approximately $0.3 \mathrm{mSv}$. The maximum individual annual TEDEs for onsite homesteaders and onsite homestead well drillers are $0.41 \mathrm{mSv}$ and $0.014 \mathrm{mSv}$ per drilling event, respectively. The maximum individual doses for the most exposed groups meet the individual dose constraint.

A similar analysis can be applied to the individual dose of the Jackass Flats community residents. The median individual annual TEDE, 4E-7 mSv, and the maximum, $0.002 \mathrm{mSv}$, are less than the suggested de minimum dose, $0.03 \mathrm{mSv}$. This supports the assumption that it is unnecessary to include more distant residents in the collective dose assessment, because their individual doses are not sufficient to constitute a regulatory concern requiring limitation. 


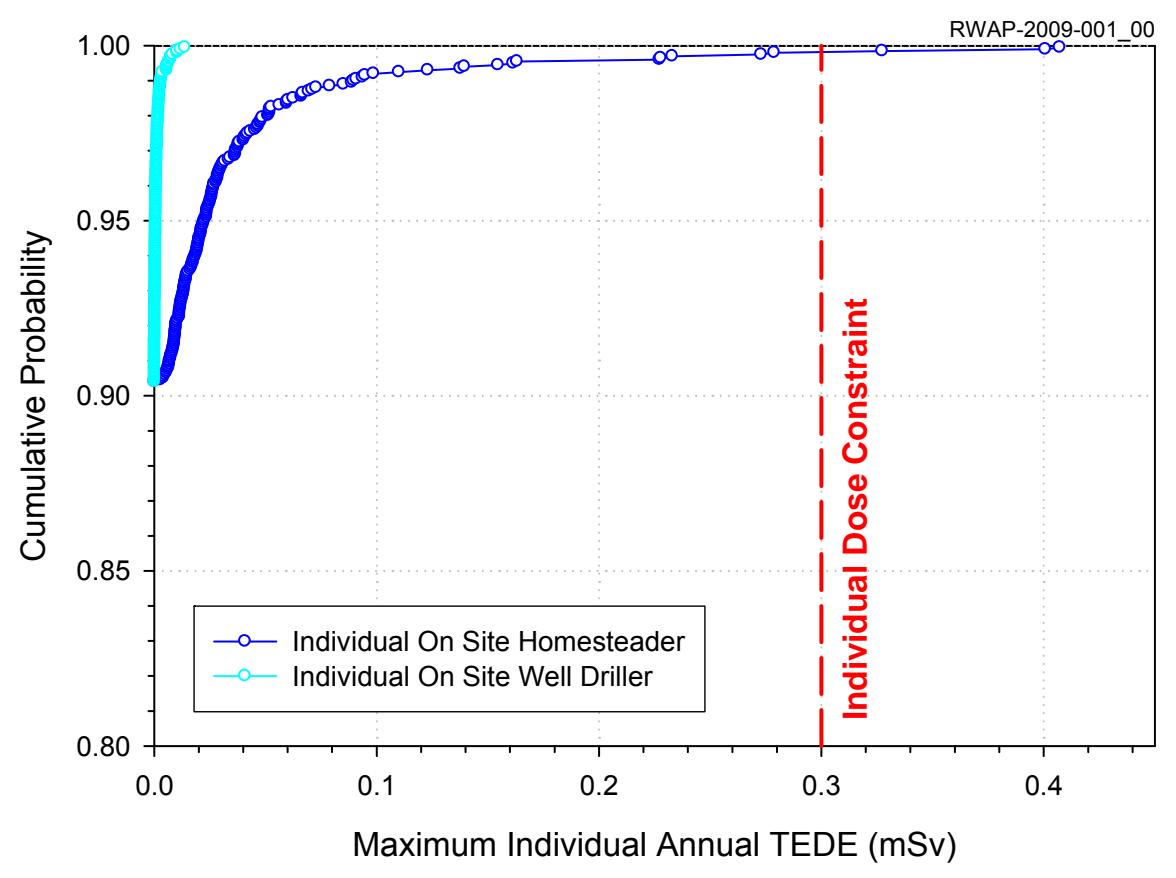

Figure 3.1 Empirical cumulative distribution function of the maximum onsite homesteader annual TEDE ( $m S v)$ and onsite homestead well driller TEDE ( $m$ Sv per drilling event) for the Area 5 RWMS with a 2.5-m closure cover

\subsection{COLLECTIVE DOSE}

The collective dose is an important intermediate result used to calculate the total closure cost. The A5 RWMS v4.102 GoldSim model is the first in the sequence of PA model versions to simulate the timing and location of future settlement and calculate the collective dose to future populations. Collective dose presents a different risk perspective for the Area 5 RWMS compared with PA and CA, which calculate individual dose at a fixed point at all times. Therefore, the collective dose results are briefly described and summarized.

The mean and $95^{\text {th }}$ percentile collective doses at 1,000 years for the entire Area 5 RWMS with a 2.5-m (8.2-ft) cover were 2.6E-3 and 2.4E-3 person-Sv, respectively (Table 3.5$)$. The $5^{\text {th }}$ percentile collective dose is zero for all options. The median collective dose is orders of magnitude less than the mean. The large difference between the mean and median reflects the large positive skew in the data caused by summing the collective dose over six populations with very different dose distributions.

Table 3.5 Summary statistics for collective dose for the Area 5 RWMS

\begin{tabular}{|c|c|c|c|c|c|}
\hline \multirow{2}{*}{ Statistic } & \multicolumn{5}{|c|}{ Collective Dose (person-Sv) } \\
\cline { 2 - 6 } & $2.5 \mathrm{~m}$ & $3.0 \mathrm{~m}$ & $3.5 \mathrm{~m}$ & $4.0 \mathrm{~m}$ & $4.5 \mathrm{~m}$ \\
\hline Mean & $2.6 \mathrm{E}-03$ & $1.9 \mathrm{E}-03$ & $1.5 \mathrm{E}-03$ & $1.2 \mathrm{E}-03$ & $9.4 \mathrm{E}-04$ \\
\hline Median & $9.0 \mathrm{E}-07$ & $3.7 \mathrm{E}-07$ & $2.7 \mathrm{E}-07$ & $2.4 \mathrm{E}-07$ & $2.3 \mathrm{E}-07$ \\
\hline 5th percentile & $0.0 \mathrm{E}+00$ & $0.0 \mathrm{E}+00$ & $0.0 \mathrm{E}+00$ & $0.0 \mathrm{E}+00$ & $0.0 \mathrm{E}+00$ \\
\hline 95th percentile & $2.4 \mathrm{E}-03$ & $1.9 \mathrm{E}-03$ & $1.7 \mathrm{E}-03$ & $1.4 \mathrm{E}-03$ & $1.3 \mathrm{E}-03$ \\
\hline
\end{tabular}


The distribution of collective dose at 1,000 years has at least two modes (Figure 3.2). The higher collective dose mode corresponds with onsite residents, and the lower mode with offsite residents. The mean is significantly greater than the median throughout the 1,000 year evaluation interval due to a small number of high collective dose realizations from onsite residents. The skew increases beyond 500 years as low probability, high consequence onsite communities begin to appear.

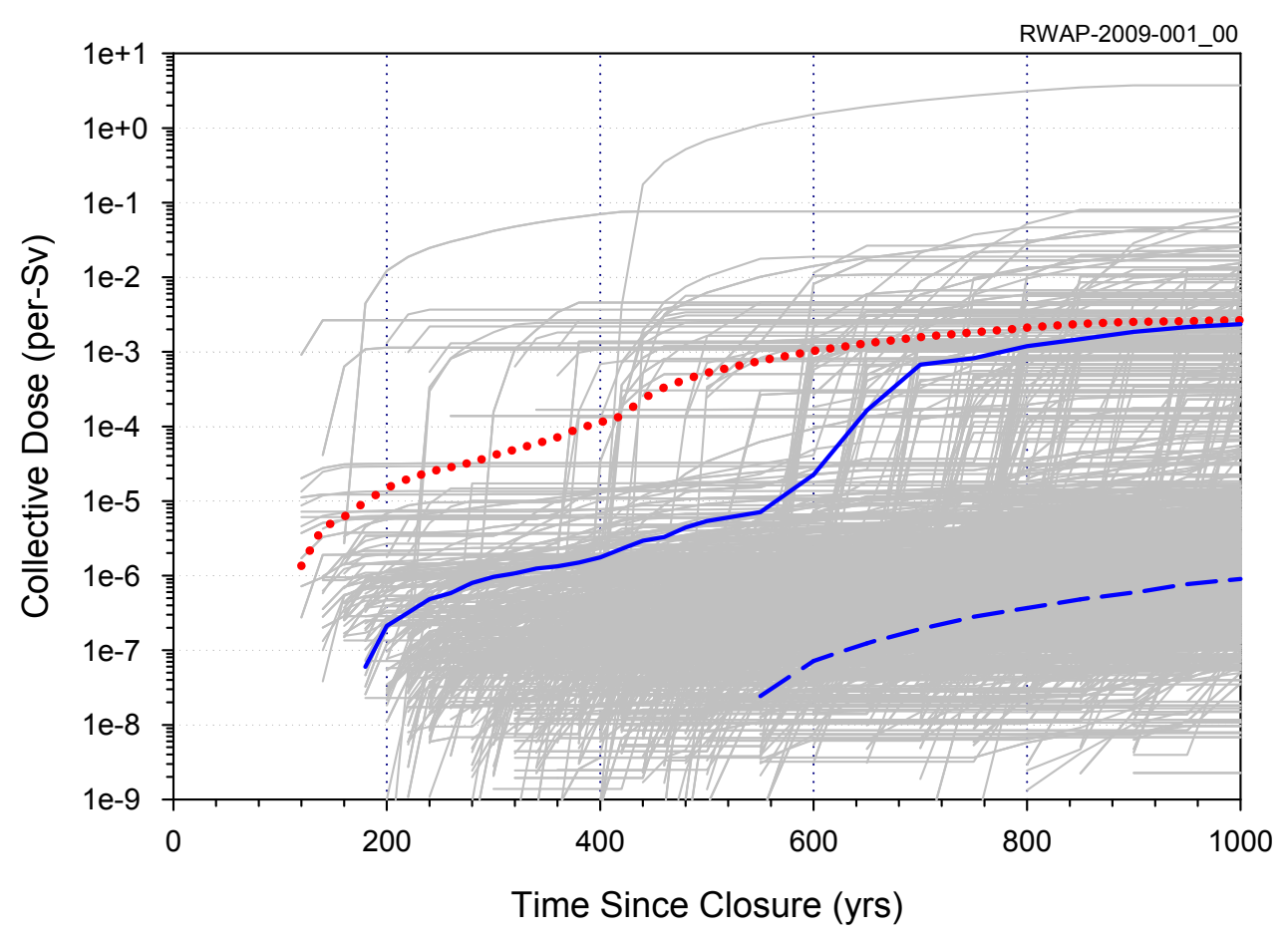

Figure 3.2 Collective dose over time for the Area 5 RWMS with a 2.5-m closure cover. Mean (solid blue), median (dashed blue), and $95^{\text {th }}$ percentile (dotted red) shown with 2,000 realizations (gray)

The collective dose is contributed mostly by onsite residents for 1,000 years (Figure 3.3). Onsite homesteaders are the primary source of collective dose for the first 440 years. Thereafter, onsite community residents are the most important source of collective dose. The appearance of an onsite community is a much rarer event than the presence of onsite homesteaders. In 2,000 realizations, one onsite community occurred. The area of community overlap with the Area 5 RWMS was small, and all of the randomly located community wells were outside the RWMS. Consequently, the collective dose for onsite community well drillers was zero for all 2,000 realizations. Even with 10,000 model realizations, the occurrence of onsite community drillers is a rare event.

Among offsite groups, the largest collective dose is expected for the residents of the Jackass Flats/Mercury community for the first 440 years after closure. Beyond 440 years, offsite community residents are the most important due to a model realization where a community overlaps the Area 5 RWMS. For the Jackass Flats scenario, the founding community in Jackass Flats or Mercury is the largest source of collective dose throughout the 1,000 year evaluation period. 


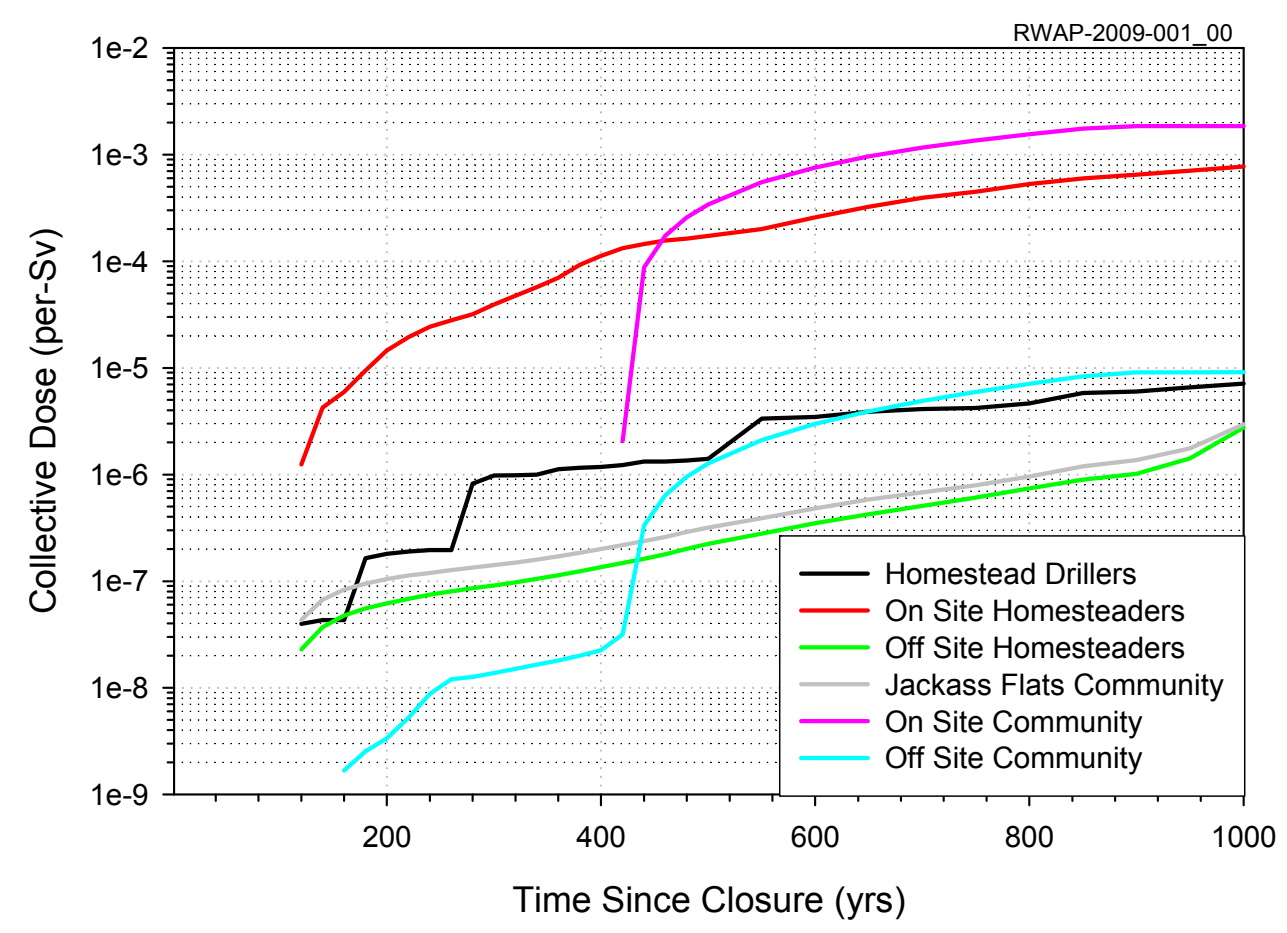

Figure 3.3 Mean collective dose over time, disaggregated by subgroup for the Area 5 RWMS with a 2.5-m closure cover

The predominant source of collective dose for onsite residents is external irradiation by ${ }^{222} \mathrm{Rn}$ and its short-lived progeny in cover soil (Figure 3.4). The second, and much less important, source of collective dose is inadvertent ingestion of ${ }^{238} \mathrm{U}+\mathrm{P}$ in cover soil, where " $+\mathrm{P}$ " indicates that the dose from short-lived progeny in secular equilibrium is included. 


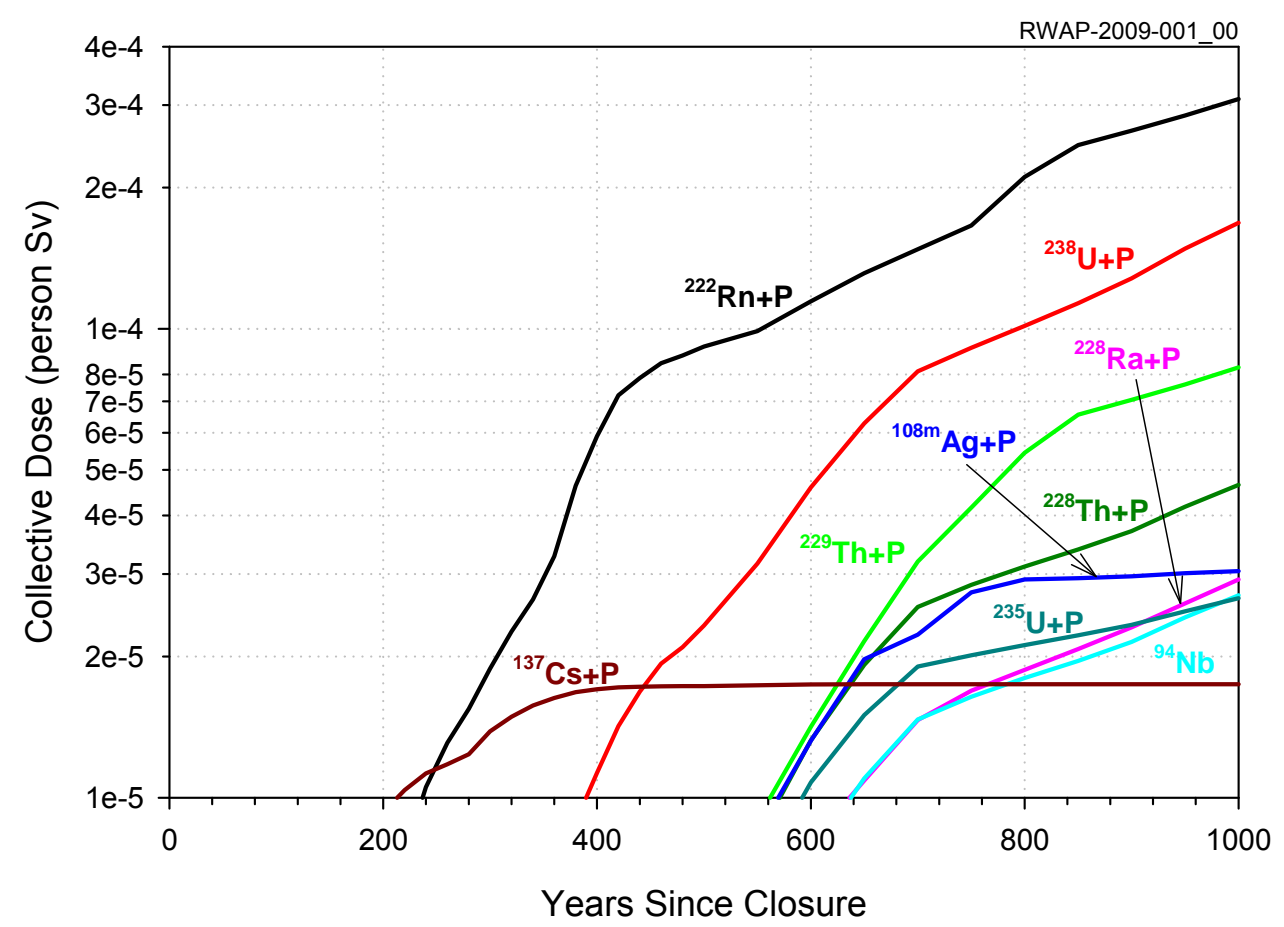

Figure 3.4 Mean onsite homesteader collective dose over time by radionuclide for the Area 5 RWMS with a 2.5-m closure cover

Offsite resident collective dose is contributed predominantly by ${ }^{137} \mathrm{Cs}+\mathrm{P}$ for the first 500 years after closure (Figure 3.5). Afterwards, ${ }^{238} \mathrm{U}+\mathrm{P}$ becomes the most important source of offsite collective dose. From 900 to 1,000 years, ${ }^{108 \mathrm{~m}} \mathrm{Ag}+\mathrm{P}$ is the most important source of collective dose. The abrupt increase in collective dose from ${ }^{108 \mathrm{~m}} \mathrm{Ag}+\mathrm{P}$ is due to the random occurrence of an offsite homestead during a realization with a large ${ }^{108 \mathrm{~m}} \mathrm{Ag}$ inventory. Collective dose is sensitive to ${ }^{108 \mathrm{~m}} \mathrm{Ag}$ because it has a large dose conversion coefficient and its inventory has a large uncertainty. The source of the ${ }^{108 \mathrm{~m}} \mathrm{Ag}$ inventory is largely the future inventory projection, which has a high uncertainty. 


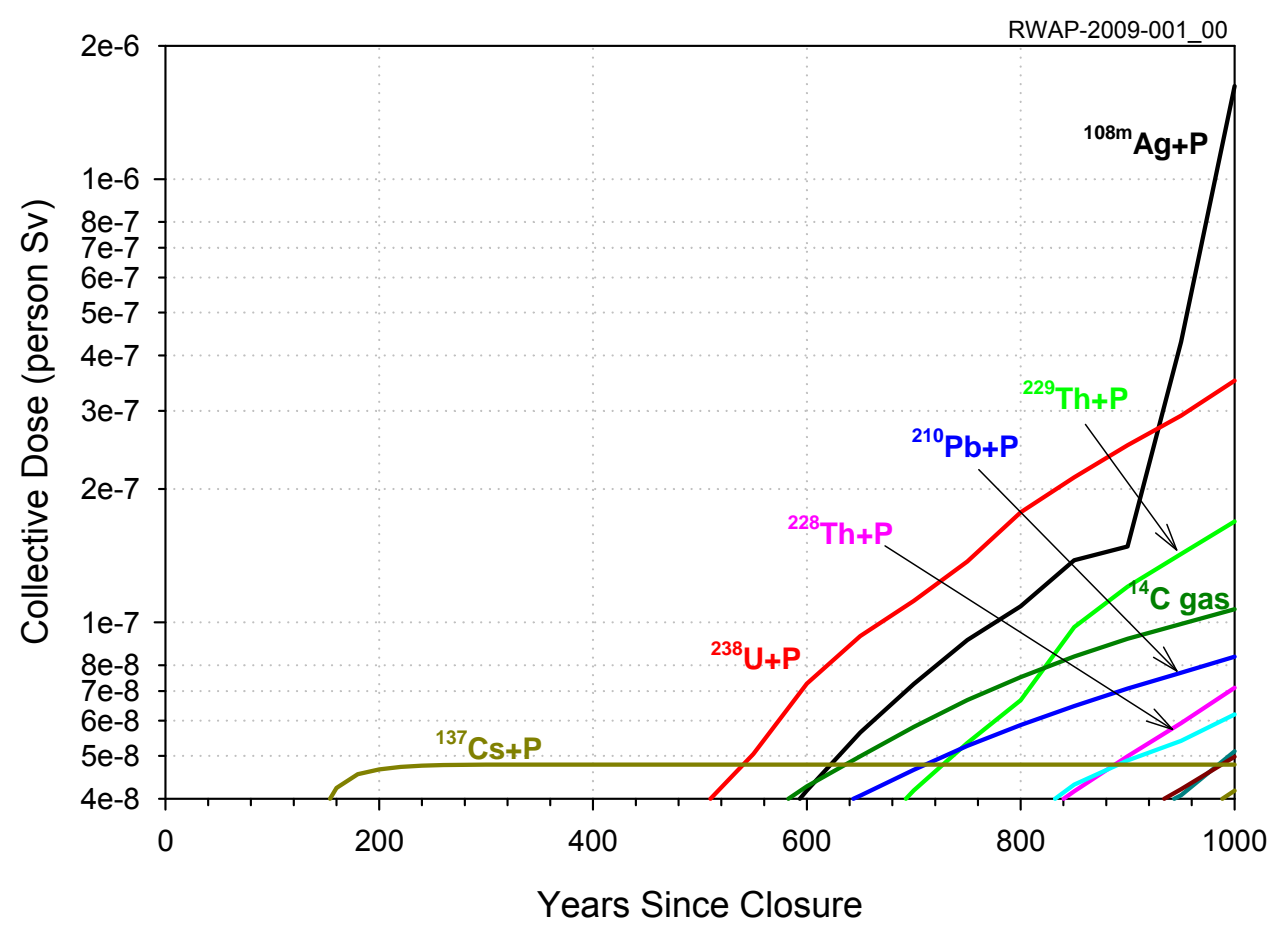

Figure 3.5 Mean offsite homesteader collective dose over time by radionuclide for the Area 5 RWMS with a 2.5-m closure cover

Previous Area 5 RWMS PA/CA results have shown a decreasing relationship between member of public dose and cover thickness, and a similar relationship might be expected for collective dose. While there is a statistically significant decreasing trend in collective dose with cover thickness, the mean, median, and $95^{\text {th }}$ percentile show no strong relationship (Figure 3.6). The collective dose is contributed mostly by onsite residents who are exposed predominantly to waste released by water well drilling. The amount of contamination released by well drilling is independent of cover thickness, thus explaining the generally weak relationship between collective dose and cover thickness. 


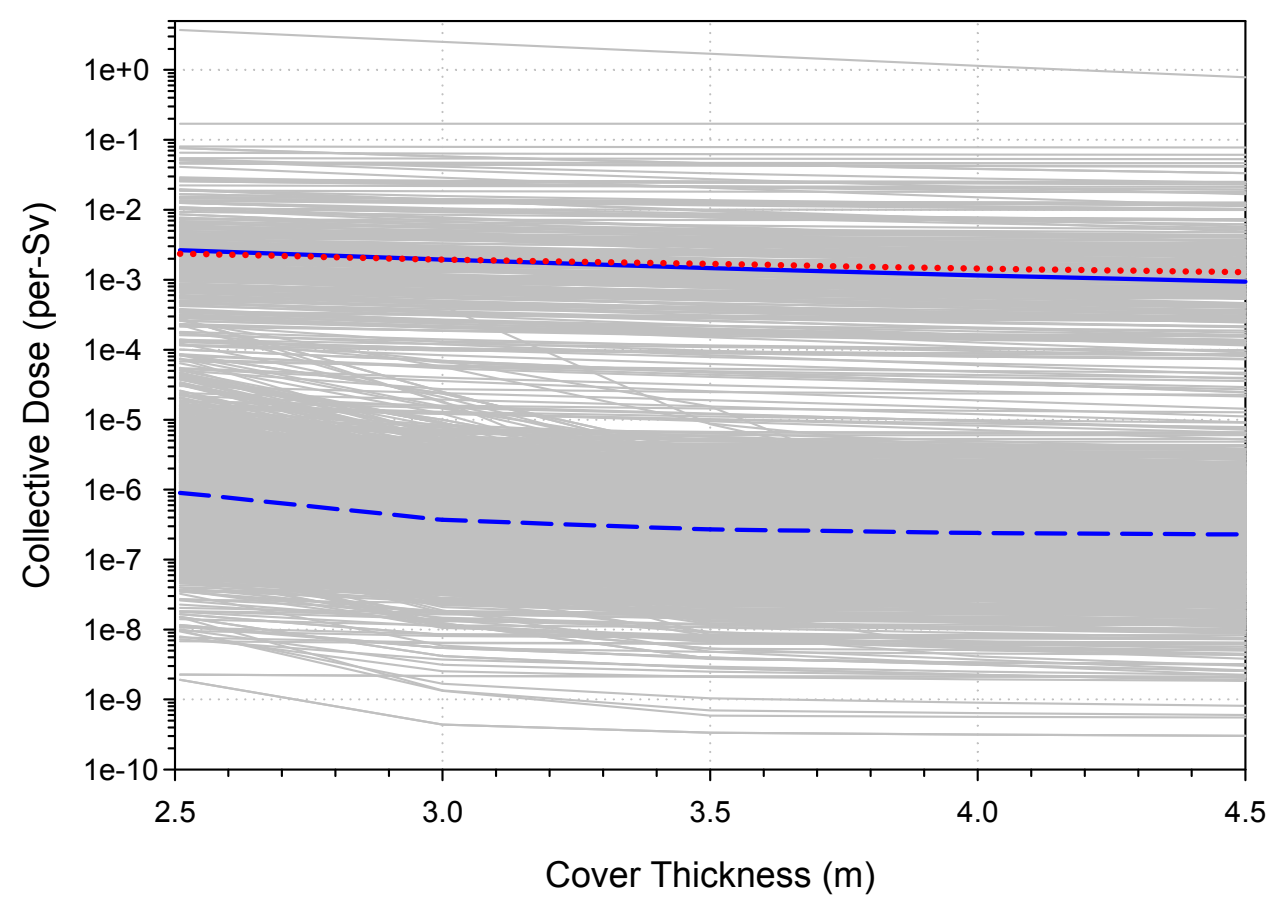

Figure 3.6 Collective dose versus cover thickness for the Area 5 RWMS. Mean (solid blue), median (dashed blue), and $95^{\text {th }}$ percentile (dotted red) shown with 2,000 realizations (gray)

\subsection{OPTIMIZATION RESULTS}

\subsubsection{Optimization of the 92-ac LLWMU Closure Cover}

The total cost of closure for the 92-ac LLWMU is an increasing function of cover thickness over the range evaluated, 2.5 to $4.5 \mathrm{~m}$ (8.2 to $15 \mathrm{ft}$ ) (Figure 3.7). The relationship is linear, except for a single realization where the slope decreases with decreasing cover thickness. The total closure cost variance increases with cover thickness, but the coefficient of variation is relatively constant. The linearly increasing curves indicate that range of options considered occurs in a region where closure costs are dominated by cover construction costs (i.e., region III in Figure 2.1). The minimum total cost, corresponding to the optimum level of radiation protection, occurred at the minimum cover thickness, $2.5 \mathrm{~m}(8.2 \mathrm{ft})$, for all 2,000 realizations. 


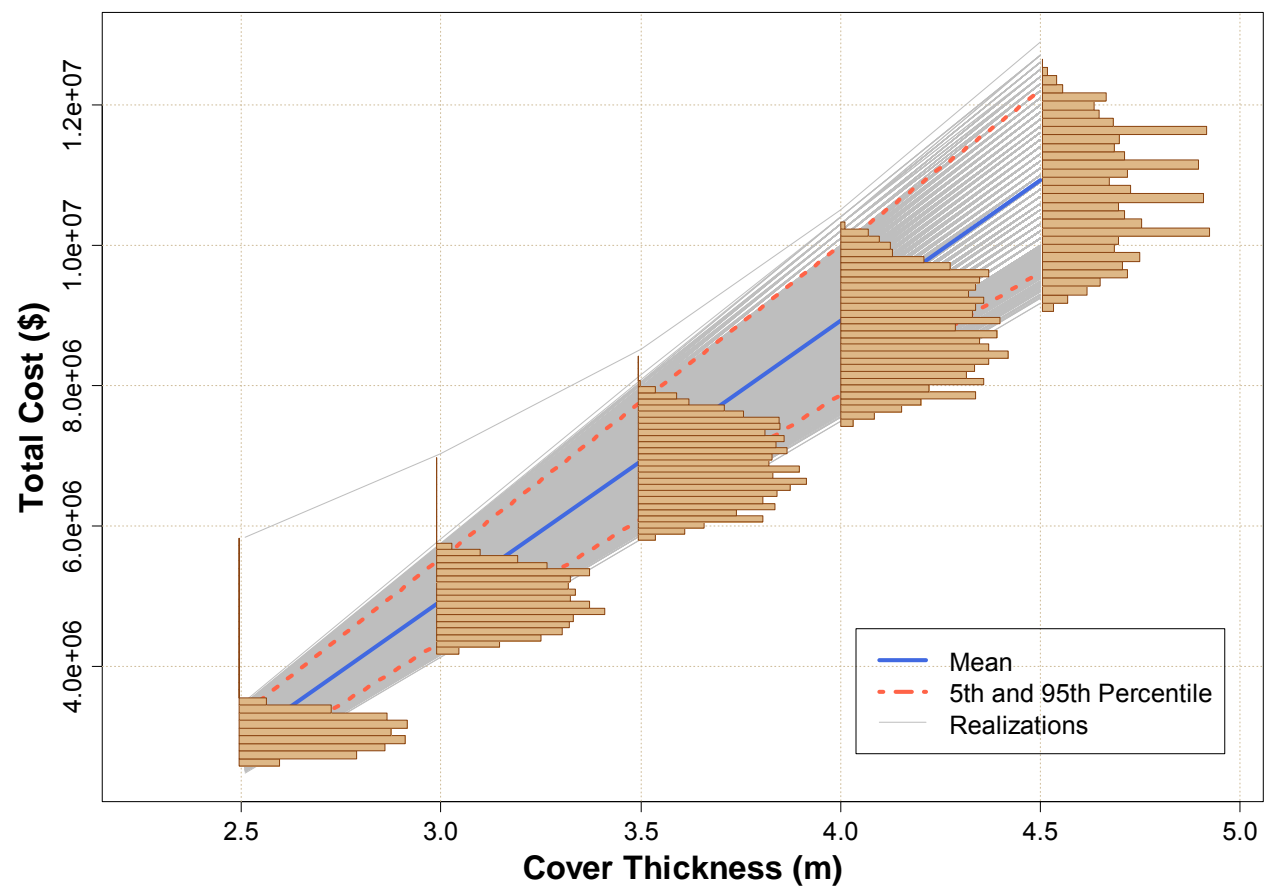

Figure 3.7 Total closure cost versus cover thickness for closure of the 92-acre LLWMU

The mean total cost for a $2.5 \mathrm{~m}(8.2 \mathrm{ft})$ cover was 3 million dollars (Table 3.6). The total cost is contributed almost entirely by the cover construction cost.

Table 3.6 Summary statistics for total escalated closure costs for the 92-ac LLWMU.

\begin{tabular}{|c|c|c|c|c|c|}
\hline \multirow{2}{*}{ Statistic } & \multicolumn{5}{|c|}{ Total Closure Cost (\$) } \\
\cline { 2 - 6 } & $2.5 \mathrm{~m}$ & $3.0 \mathrm{~m}$ & $3.5 \mathrm{~m}$ & $4.0 \mathrm{~m}$ & $4.5 \mathrm{~m}$ \\
\hline Mean & $3.0 \mathrm{E}+06$ & $4.9 \mathrm{E}+06$ & $6.9 \mathrm{E}+06$ & $8.9 \mathrm{E}+06$ & $1.1 \mathrm{E}+07$ \\
\hline Median & $3.0 \mathrm{E}+06$ & $4.9 \mathrm{E}+06$ & $6.9 \mathrm{E}+06$ & $8.9 \mathrm{E}+06$ & $1.1 \mathrm{E}+07$ \\
\hline 5th percentile & $2.6 \mathrm{E}+06$ & $4.3 \mathrm{E}+06$ & $6.1 \mathrm{E}+06$ & $7.9 \mathrm{E}+06$ & $9.6 \mathrm{E}+06$ \\
\hline 95th percentile & $3.3 \mathrm{E}+06$ & $5.5 \mathrm{E}+06$ & $7.8 \mathrm{E}+06$ & $1.0 \mathrm{E}+07$ & $1.2 \mathrm{E}+07$ \\
\hline
\end{tabular}

\subsubsection{Optimization of the Northern Expansion Area Closure Cover}

The total cost of closure for the Northern Expansion Area is a linearly increasing function of cover thickness over the range evaluated, 2.5- to 4.5-m (8.2- to 15-ft) (Figure 3.8). The linearly increasing closure cost indicates that construction costs are the primary source. The Northern Expansion Area total closure cost has a weaker relationship with cover thickness than found for the 92-ac LLWMU. The minimum total cost, corresponding to the optimum level of radiation protection, occurred at the minimum cover thickness, $2.5 \mathrm{~m}(8.2 \mathrm{ft})$, for all 2,000 realizations. 


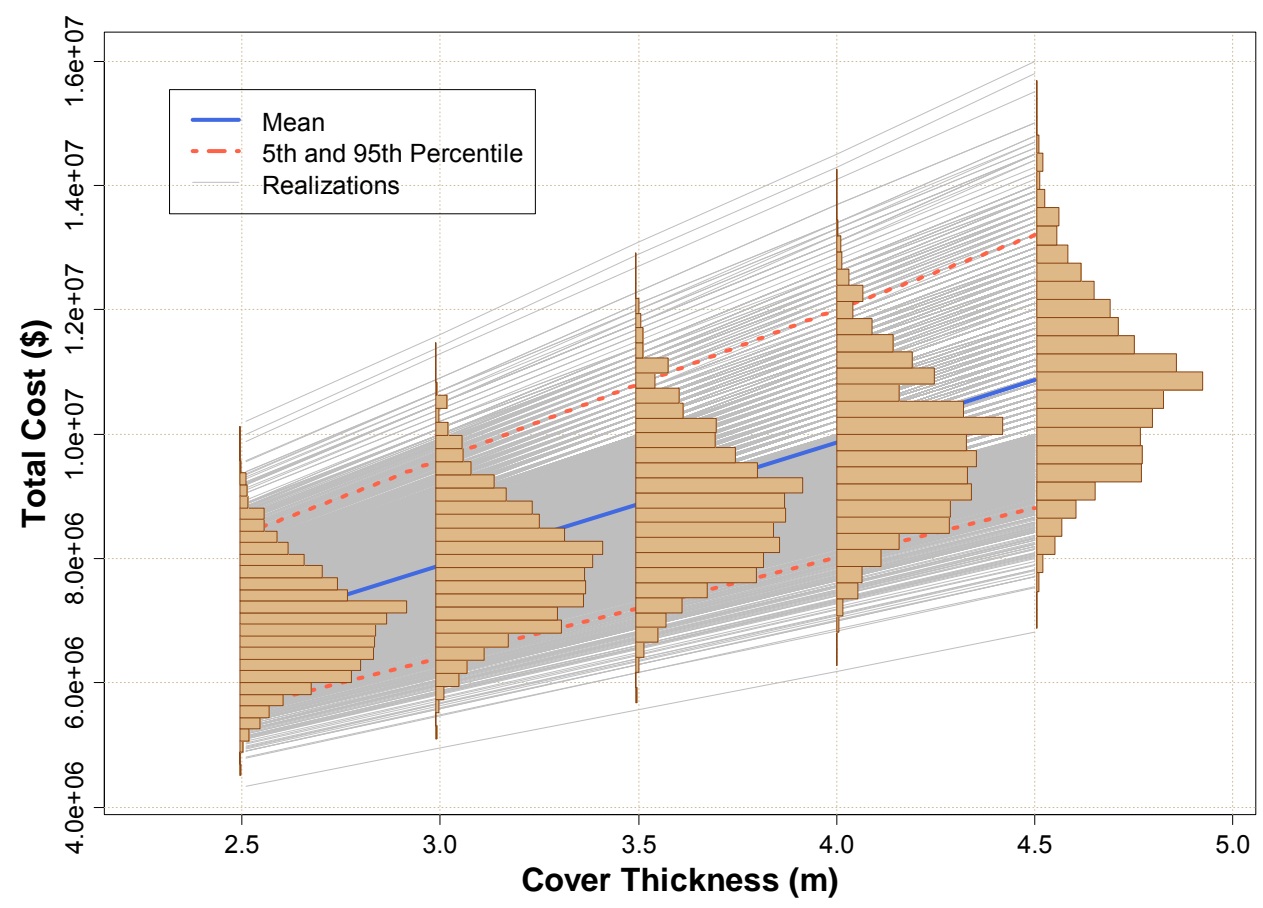

Figure 3.8 Total cost versus cover thickness for closure of the Northern Expansion Area

The mean total cost of 6.9 million dollars for the $2.5-\mathrm{m}(8.2-\mathrm{ft})$ cover is nearly double the cost for the 92-ac LLWMU (Table 3.7). The escalation of construction costs from 2008 to 2028 is the major factor increasing the cost. Although the total cost of closure of the Northern Expansion Area is increasing with cover thickness, the slope is much less than observed for the 92-ac LLWMU. The weaker relationship between total cost and cover thickness is due to the increased variance in cover construction cost caused by uncertainty in the cost escalation rate.

Table 3.7 Summary statistics for total escalated closure costs for the Northern Expansion Area

\begin{tabular}{|c|c|c|c|c|c|}
\hline \multirow{2}{*}{ Statistics } & \multicolumn{5}{|c|}{ Total Closure Cost (\$) } \\
\cline { 2 - 6 } & $2.5 \mathrm{~m}$ & $3.0 \mathrm{~m}$ & $3.5 \mathrm{~m}$ & $4.0 \mathrm{~m}$ & $4.5 \mathrm{~m}$ \\
\hline Mean & $6.9 \mathrm{E}+06$ & $7.9 \mathrm{E}+06$ & $8.9 \mathrm{E}+06$ & $9.9 \mathrm{E}+06$ & $1.1 \mathrm{E}+07$ \\
\hline Median & $6.9 \mathrm{E}+06$ & $7.8 \mathrm{E}+06$ & $8.8 \mathrm{E}+06$ & $9.8 \mathrm{E}+06$ & $1.1 \mathrm{E}+07$ \\
\hline 5th percentile & $5.6 \mathrm{E}+06$ & $6.4 \mathrm{E}+06$ & $7.2 \mathrm{E}+06$ & $8.0 \mathrm{E}+06$ & $8.8 \mathrm{E}+06$ \\
\hline 95th percentile & $8.4 \mathrm{E}+06$ & $9.6 \mathrm{E}+06$ & $1.1 \mathrm{E}+07$ & $1.2 \mathrm{E}+07$ & $1.3 \mathrm{E}+07$ \\
\hline
\end{tabular}

\subsubsection{Optimization of the Area 5 RWMS Closure Cover}

The total cost of closure for the entire Area 5 RWMS is the sum of the costs for the 92-ac LLWMU and the Northern Expansion Area. As for the two other areas, the total closure cost is a linearly increasing function of cover thickness over the range evaluated, 2.5 to $4.5 \mathrm{~m}$ (8.2 to $15 \mathrm{ft}$ ) (Figure 3.9). The minimum total cost, corresponding to the optimum level of radiation protection, occurred at the minimum cover thickness, $2.5 \mathrm{~m}(8.2 \mathrm{ft})$, for all 2,000 realizations. 


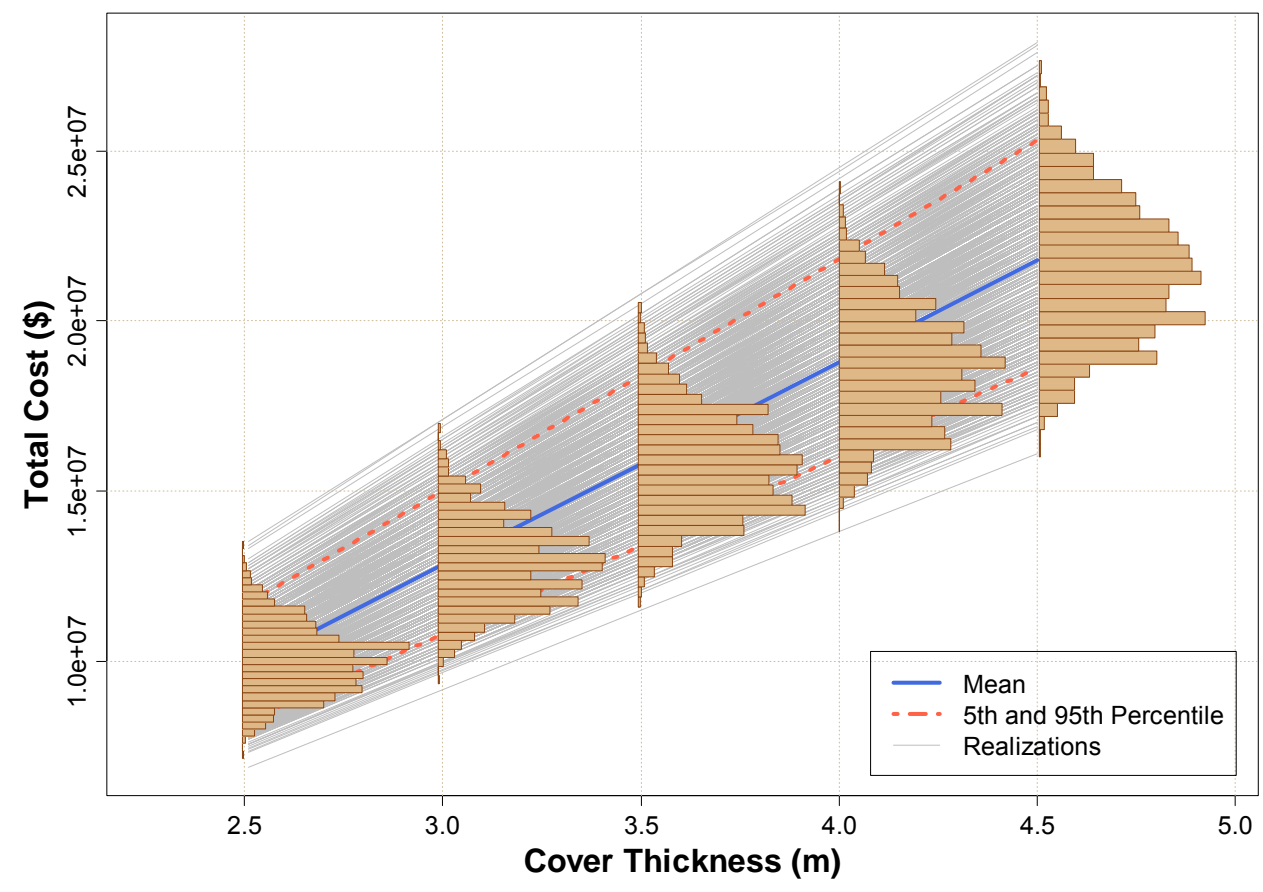

Figure 3.9 Total cost versus cover thickness for closure of the entire Area 5 RWMS

The 9.9 million dollar cost estimate for the $2.5-\mathrm{m}(8.2-\mathrm{ft})$ cover cost is contributed mostly by cost for the Northern Expansion Area (Table 3.8). The linearly increasing closure cost is indicative that construction costs are the primary source of the closure cost.

Table 3.8 Summary statistics for total escalated closure costs for the Area 5 RWMS

\begin{tabular}{|c|c|c|c|c|c|}
\hline \multirow{2}{*}{ Statistics } & \multicolumn{5}{|c|}{ Total Closure Cost (\$) } \\
\cline { 2 - 6 } & $2.5 m$ & $3.0 m$ & $3.5 m$ & $4.0 m$ & $4.5 m$ \\
\hline Mean & $9.9 \mathrm{E}+06$ & $1.3 \mathrm{E}+07$ & $1.6 \mathrm{E}+07$ & $1.9 \mathrm{E}+07$ & $2.2 \mathrm{E}+07$ \\
\hline Median & $9.9 \mathrm{E}+06$ & $1.3 \mathrm{E}+07$ & $1.6 \mathrm{E}+07$ & $1.9 \mathrm{E}+07$ & $2.2 \mathrm{E}+07$ \\
\hline 5th per & $8.3 \mathrm{E}+06$ & $1.1 \mathrm{E}+07$ & $1.3 \mathrm{E}+07$ & $1.6 \mathrm{E}+07$ & $1.9 \mathrm{E}+07$ \\
\hline 95th per & $1.2 \mathrm{E}+07$ & $1.5 \mathrm{E}+07$ & $1.8 \mathrm{E}+07$ & $2.2 \mathrm{E}+07$ & $2.5 \mathrm{E}+07$ \\
\hline
\end{tabular}

\subsection{UNCERTAINTY ANALYSIS}

Uncertainty analysis is the process of quantifying the uncertainty in model outputs. Uncertainty analysis can be used to assess the likelihood of exceeding a regulatory limit, to inform decision makers on the reliability of a model result, to identify important sources of uncertainty or disagreement, and to identify a need for additional data collection. The model end point selected for uncertainty analysis is the optimum cover thickness.

The uncertainty analysis uses Monte Carlo simulation to propagate input parameter uncertainties through the mathematical model to the output. In addition, uncertainty contributed by the monetary value of health detriment, an important value parameter, and the collective dose integration period are assessed by observing the effects of one-at-a-time model changes. Model 
and scenario uncertainty are not addressed by the uncertainty analysis. Uncertainty in the patterns and timing of future settlement near the Area 5 RWMS may be significant. The scenarios used are based on the elicitation of SMEs. The elicitation included estimates of the SMEs uncertainty, and this uncertainty is included in parameters estimated from elicitation results.

\subsubsection{Sample Size}

Monte Carlo analysis requires a sample size that balances the benefits of high precision against the cost of computer realizations. The precision of total closure costs as a function of sample size was investigated over a range of 500 to 3,000 realizations (Figure 3.10). The mean and $90^{\text {th }}$ percentile appear to be relatively stable over the range investigated. The variation is small compared to the 30 percent uncertainty estimated for the cover construction costs. A sample size of 2,000 was selected for the cost-benefit optimization as a compromise, giving the highest possible precision while maintaining reasonable run times and file sizes.

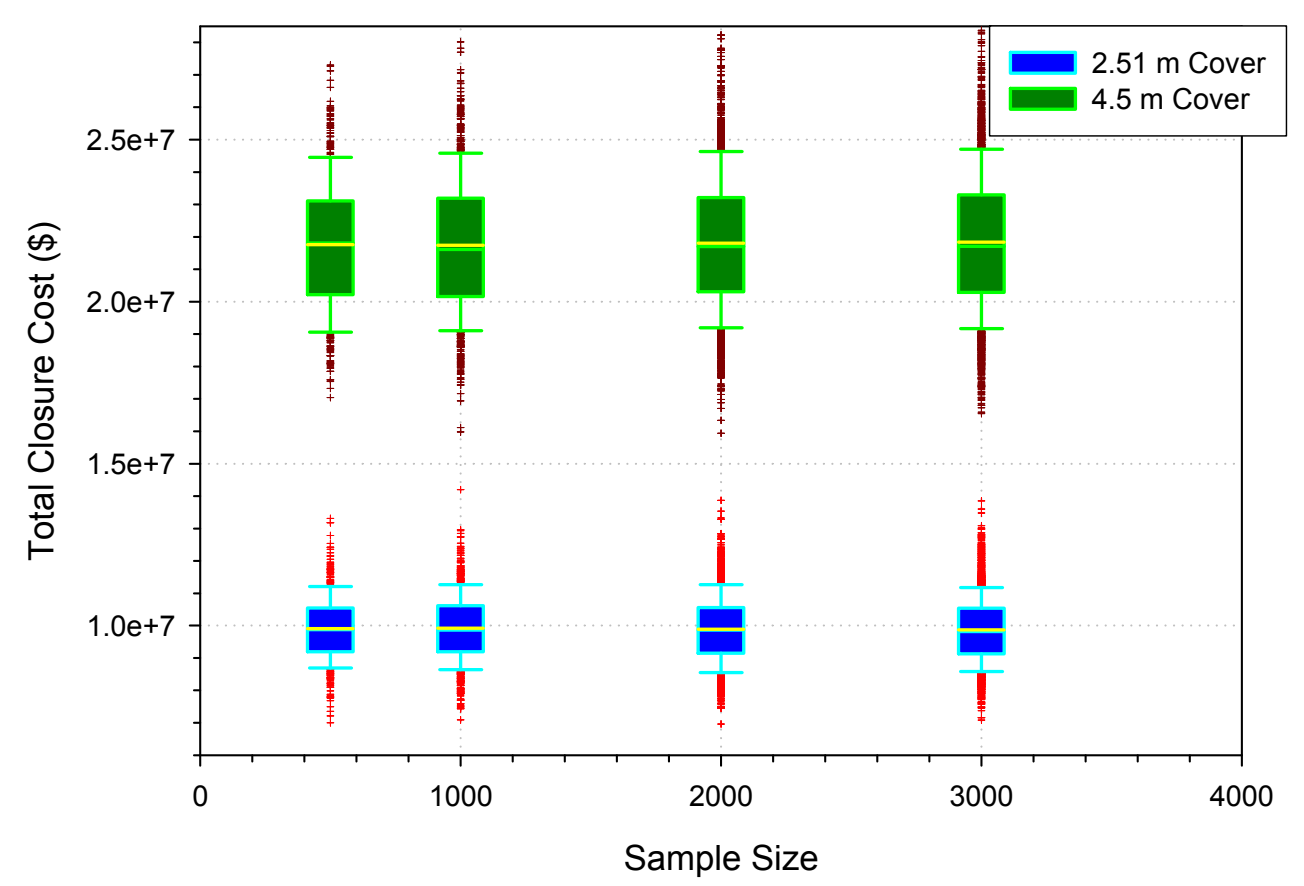

Figure 3.10 Mean (green or blue), median (yellow), $10^{\text {th }}$ and $90^{\text {th }}$ percentiles (whiskers), and outliers (crosses) of the total closure cost for the Area 5 RWMS with a 2.5- and 4.5-m closure cover as a function of sample size

\subsubsection{Parameter Uncertainty}

The optimum closure cover thickness corresponds with the minimum total closure cover cost. Parameter uncertainty along with spatial and temporal variability in settlement patterns were propagated through the model by Monte Carlo simulation with random settlement events. The 2,000 model results are assumed to fully represent uncertainty in the optimum cover thickness. 
For the three disposal configurations considered, the 92-ac LLWMU, the Northern Expansion Area, and the total Area 5 RWMS, total closure costs were found to be a monotonically increasing function of cover thickness for all realizations. In this case, the minimum closure cost over the range of cover thicknesses considered is clearly the minimum cover cost, which corresponds to the $2.5-\mathrm{m}(8.2-\mathrm{ft})$ cover. The true minimum cost was not found but must be less than $2.5-\mathrm{m}(8.2-\mathrm{ft})$. The distribution of the optimum cover thickness for all three disposal configurations consists of 2,000 results of less than $2.5-\mathrm{m}(8.2-\mathrm{ft})$. Therefore, there is very high confidence that the optimum cover thickness is less than $2.5-\mathrm{m}(8.2-\mathrm{ft})$ and that increasing cover thickness beyond $2.5-\mathrm{m}(8.2-\mathrm{ft})$ is not cost-effective.

\subsubsection{Alternative Monetary Value of Collective Dose}

The monetary value of collective dose is considered a subjective value parameter. The optimization was performed using a value of $\$ 200,000$ per person-Sv in 1990 dollars, as recommended by regulatory agencies. This section describes the consequence of increasing the value of collective dose from $\$ 200,000$ to $\$ 15,000,000$ per person-Sv.

\subsubsection{92-ac LLWMU}

Increasing the monetary value of collective dose to an upper limit value has no significant impact on the total closure cost for a 2.5-m (8.2-ft) closure cover on the 92-ac LLWMU (Table 3.9). The insensitivity to the monetary value of collective dose reflects that the total closure costs are determined predominately by the cover construction costs.

Table 3.9 Comparison of total closure costs for a 2.5-m cover on the 92-ac LLWMU assuming a representative and upper limit value of the monetary value of health detriment

\begin{tabular}{|c|c|c|}
\hline \multirow{2}{*}{ Statistic } & \multicolumn{2}{|c|}{$2.5 \mathrm{~m}$ Closure Cover for 92-ac LLWMU } \\
\cline { 2 - 3 } & $\begin{array}{c}\text { \$200,000 per person-Sv } \\
\text { (1990 Dollars) }\end{array}$ & $\begin{array}{c}\text { \$15,000,000 per person-Sv } \\
\text { (1990 Dollars) }\end{array}$ \\
\hline Mean & $3.0 \mathrm{E} 6$ & $3.1 \mathrm{E} 6$ \\
\hline Median & $3.0 \mathrm{E} 6$ & $3.0 \mathrm{E} 6$ \\
\hline $5^{\text {th }}$ Percentile & $2.6 \mathrm{E} 6$ & $2.6 \mathrm{E} 6$ \\
\hline $95^{\text {th }}$ Percentile & $3.4 \mathrm{E} 6$ & $3.4 \mathrm{E} 6$ \\
\hline
\end{tabular}

For all realizations except one, the total closure costs are a monotonically increasing function of cover thickness (Figure 3.11). One realization displays a decreasing relationship between total closure cost and cover thickness. The distribution of the optimum cover thickness consists of 1,999 realizations of less than $2.5 \mathrm{~m}(8.2-\mathrm{ft})$ and one realization of greater that $4.5 \mathrm{~m}(15 \mathrm{ft})$. Therefore, there is high confidence that the optimum cover thickness for closure of the 92-ac LLWMU is less than $2.5 \mathrm{~m}(8.2 \mathrm{ft})$, assuming an upper limit for the monetary value of the collective dose. The optimum cover thickness for closure of the 92-ac LLWMU is insensitive to the monetary value of the health detriment over the range of cover thicknesses evaluated. 


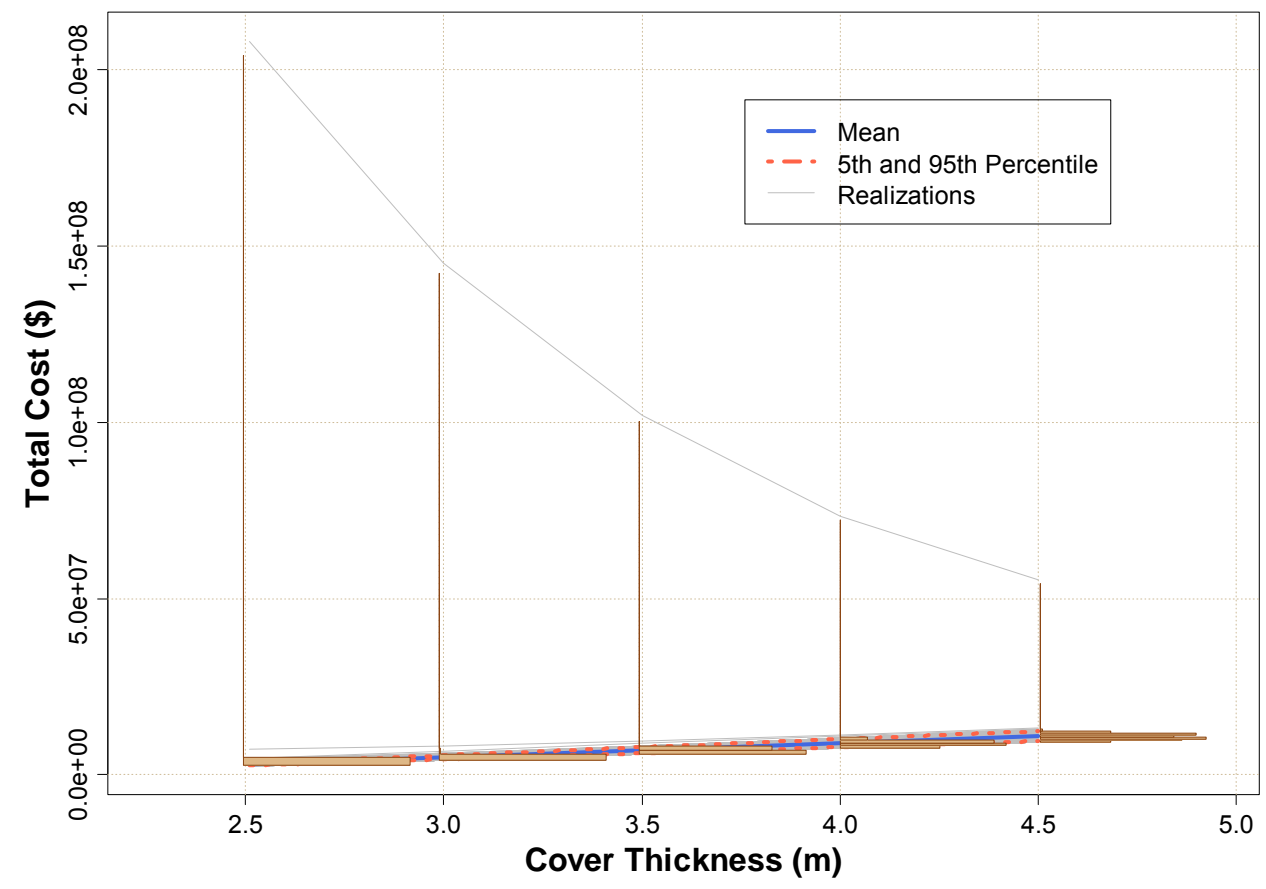

Figure 3.11 Total closure cost of the 92-ac LLWMU versus cover thickness assuming an upper limit monetary value for collective dose

\subsubsection{Northern Expansion Area}

Closure costs for the Northern Expansion Area also appear to be insensitive to the monetary value of the collective dose (Table 3.10). The Northern Expansion Area closure cost is dominated by the cover construction cost and is insensitive to the value of the collective dose.

Table 3.10 Comparison of total closure costs for a 2.5-m cover on the Northern Expansion Area assuming a representative and upper limit value of the health detriment

\begin{tabular}{|c|c|c|}
\hline \multirow{2}{*}{ Statistic } & \multicolumn{2}{|c|}{2.5 m Closure Cover for the Northern Expansion Area } \\
\cline { 2 - 3 } & $\begin{array}{c}\$ 200,000 \text { per person-Sv } \\
(1990 \text { Dollars })\end{array}$ & $\begin{array}{c}\text { \$15,000,000 per person-Sv } \\
\text { (1990 Dollars) }\end{array}$ \\
\hline Mean & $6.9 \mathrm{E} 6$ & $6.9 \mathrm{E} 6$ \\
\hline Median & $6.9 \mathrm{E} 6$ & $6.9 \mathrm{E} 6$ \\
\hline $5^{\text {th }}$ Percentile & $5.6 \mathrm{E} 6$ & $5.6 \mathrm{E} 6$ \\
\hline $95^{\text {th }}$ Percentile & $8.4 \mathrm{E} 6$ & $8.4 \mathrm{E} 6$ \\
\hline
\end{tabular}

The distribution of the optimum cover thickness is affected slightly by increasing the value of the collective dose. All realizations except one are a monotonically increasing function of the cover thickness, indicating an optimum cover thickness of less than $2.5 \mathrm{~m}(8.2 \mathrm{ft})$ (Figure 3.12). A single realization reached a minimum total cost at approximately $4.0 \mathrm{~m}(13 \mathrm{ft})$. There is a high confidence that the optimum cover thickness for the Northern Expansion Area is less than $2.5 \mathrm{~m}$ $(8.2 \mathrm{ft})$, assuming an upper limit monetary value of the collective dose. 


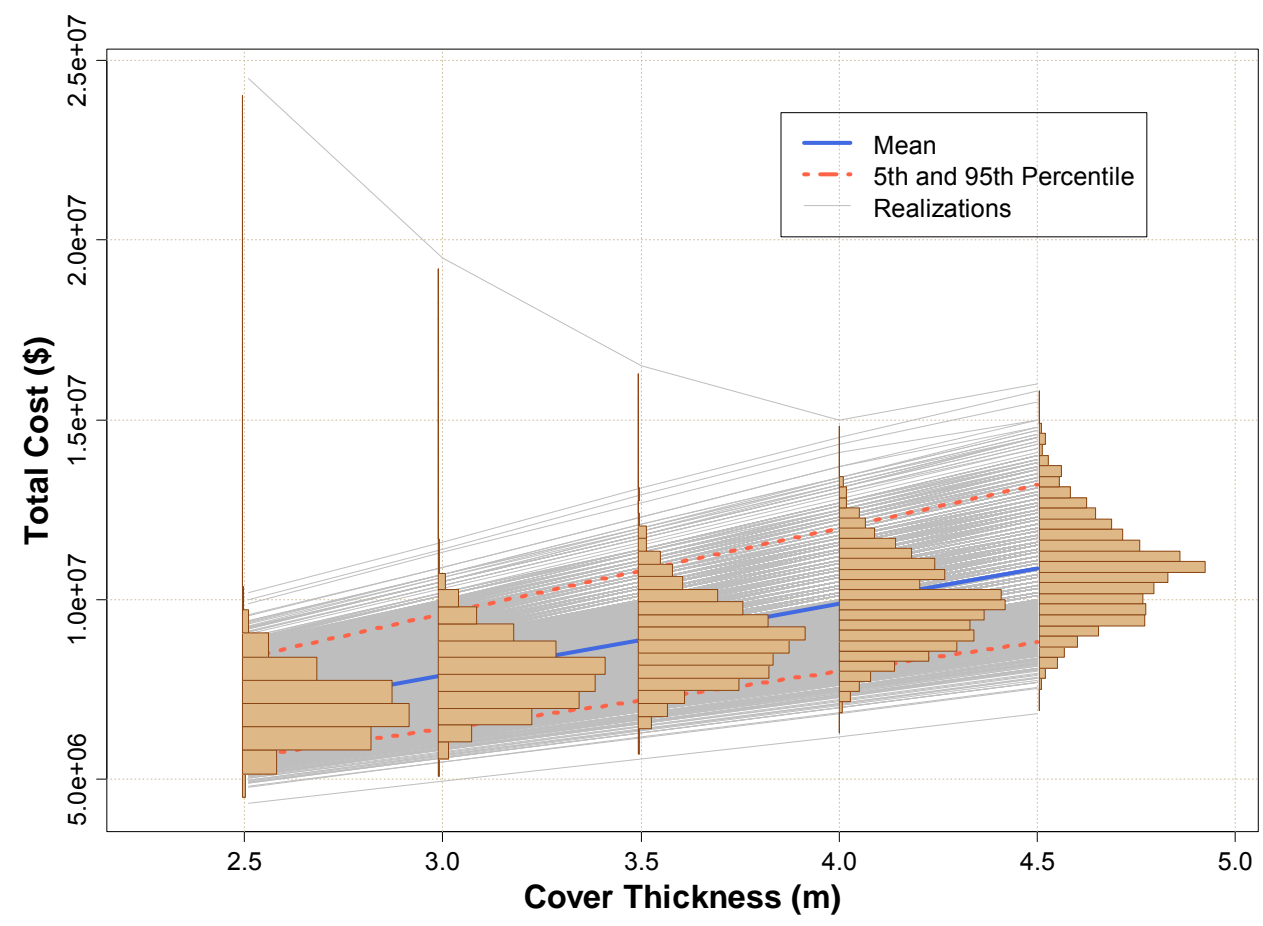

Figure 3.12 Total closure cost of the Northern Expansion Area versus cover thickness assuming an upper limit value of the collective dose

\subsubsection{Area 5 RWMS}

Total closure costs for the Area 5 RWMS are only slightly affected by using an upper limit value of the collective dose (Table 3.11).

Table 3.11 Comparison of total closure costs for a 2.5-m cover on the Area 5 RWMS assuming a representative and upper limit value of the health detriment

\begin{tabular}{|c|c|c|}
\hline \multirow{2}{*}{ Statistic } & \multicolumn{2}{|c|}{2.5 m Closure Cover for the Area 5 RWMS } \\
\cline { 2 - 3 } & $\begin{array}{c}\text { \$200,000 per person-Sv } \\
(1990 \text { Dollars })\end{array}$ & $\begin{array}{c}\$ 15,000,000 \text { per person-Sv } \\
\text { (1990 Dollars) }\end{array}$ \\
\hline Mean & $9.9 \mathrm{E} 6$ & $1.0 \mathrm{E} 7$ \\
\hline Median & $9.9 \mathrm{E} 6$ & $9.9 \mathrm{E} 6$ \\
\hline $5^{\text {th }}$ Percentile & $8.3 \mathrm{E} 6$ & $8.3 \mathrm{E} 6$ \\
\hline $95^{\text {th }}$ Percentile & $1.2 \mathrm{E} 7$ & $1.2 \mathrm{E} 7$ \\
\hline
\end{tabular}

The distribution of the optimum cover thickness for the Area 5 RWMS is not significantly altered by the upper limit monetary value of the collective dose (Figure 3.13). The mean and $95^{\text {th }}$ percentile for the optimum cover thickness remain less than $2.5 \mathrm{~m}(8.2 \mathrm{ft})$. A single realization has an optimum value greater than $4.5 \mathrm{~m}(15 \mathrm{ft})$. There is a high probability that the optimum cover thickness for the Area 5 RWMS is less than $2.5 \mathrm{~m}(8.2 \mathrm{ft})$, assuming an upper limit monetary value for collective dose. 


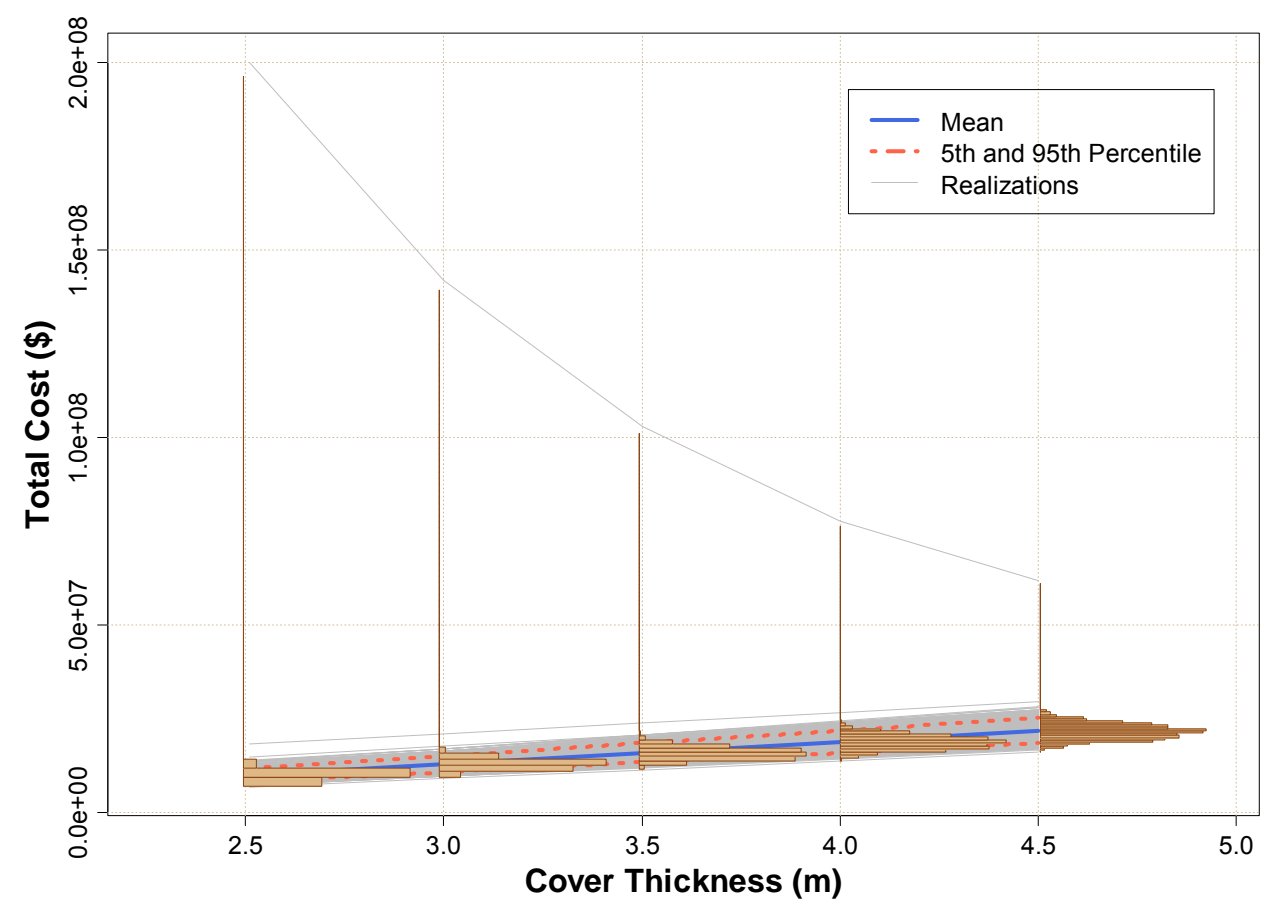

Figure 3.13 Total closure cost of the entire Area 5 RWMS versus cover thickness assuming an upper limit value of the collective dose

\subsubsection{Truncation of Collective Dose in Time}

The upper limit of integration of the collective was chosen as 1,000 years to limit model uncertainty. The effect of changing the limits of integration was investigated by extending the upper limit to 10,000 years. The dose matrix indicates that the collective dose is increasing for all exposed populations throughout the period of integration (Table 3.12). The increases are larger, on a relative basis, for offsite populations.

Table 3.12 Collective dose matrix for the Area 5 RWMS with a $2.5 \mathrm{~m}$ cover

\begin{tabular}{|c|c|c|c|}
\hline & \multicolumn{3}{|c|}{ Mean Collective Dose (person-Sv) } \\
\hline On Site & $5.2 \mathrm{E}-4$ & $2.6 \mathrm{E}-3$ & $7.4 \mathrm{E}-2$ \\
\hline Off Site, Frenchman Flat & $1.5 \mathrm{E}-6$ & $1.2 \mathrm{E}-5$ & $3.0 \mathrm{E}-3$ \\
\hline Outside Frenchman Flat & $3.2 \mathrm{E}-7$ & $3.0 \mathrm{E}-6$ & $1.5 \mathrm{E}-3$ \\
\hline
\end{tabular}

The consequence of increasing the collected dose integration period was investigated by performing the optimization with the 10,000-year collective dose estimates. Each realization of total closure costs for the Area 5 RWMS is a monotonically increasing function of cover thickness (Figure 3.14). Therefore, the minimum total closure costs occur at the minimum cover thickness evaluated, $2.5 \mathrm{~m}(8.2 \mathrm{ft})$. Because the optimum cover thickness for each of the 2,000 realizations is less than $2.5 \mathrm{~m}(8.2 \mathrm{ft})$, there is high confidence that the optimum cover thickness for a 10,000 year period is less than $2.5 \mathrm{~m}(8.2 \mathrm{ft})$. The conclusions of the cost-benefit analysis are insensitive to increasing the limit of integration for the collective dose from 1,000 to 10,000 years. 


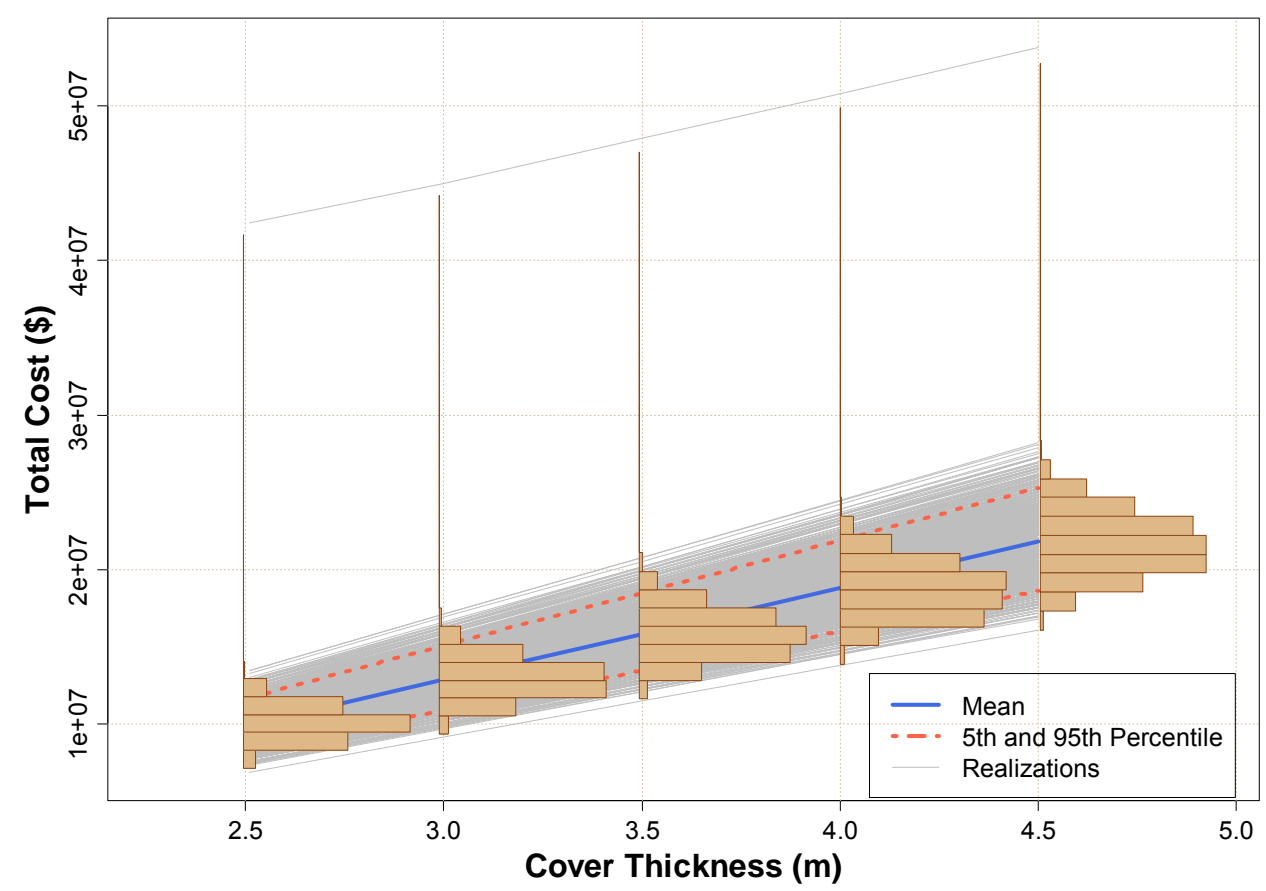

Figure 3.14 Total closure cost of the entire Area 5 RWMS versus cover thickness integrating collective dose over 10,000 years

Although the conclusions of the cost-benefit analysis are insensitive to the range of integration up to 10,000 years, the distribution of the total costs versus cover thickness is affected. The results integrated over 10,000 years include one realization with significantly higher total cost. The higher cost is caused by a significantly higher collective dose for this realization. The higher collective dose is caused by multiple occurrences of onsite homesteaders beyond 1,000 years. However, because the onsite homesteader dose is related to the activity released by drilling, which is insensitive to cover thickness, the total cost is still a monotonically increasing function of cover thickness.

\subsection{SENSITIVITY ANALYSIS}

Sensitivity analysis is the process of quantifying how uncertainty in input parameters contributes to uncertainty in model results. Sensitivity analysis is an essential component of model development which can be used to:

- Identify modeling errors

- Increase understanding of model performance

- Increase model credibility by confirming that model behavior is consistent with real system behavior or the conceptual understanding of system behavior

- Identify important sources of uncertainty or sources of disagreement among interested parties

- Quantitatively guide data collection efforts designed to reduce uncertainty 
Sensitivity analysis is performed for the optimum cover thickness and total closure cost. Sensitivity analysis of the ALARA optimization model is complicated by a large number of input variables and by the occurrence of stochastic discrete events (e.g., settlement of a community). Stochastic events cause intermediate results such as the number and location of residents to change dynamically in time. This complicates the task of determining the relationship between input parameters and final output values.

\subsubsection{Optimum Cover Thickness}

The optimum cover thickness is determined for the 92-ac LLWMU, the Northern Expansion Area, and the entire Area 5 RWMS. For each case, 2,000 realizations are generated. The optimum cover thickness for each realization for each disposal area is less than $2.5 \mathrm{~m}(8.2 \mathrm{ft})$. Therefore, the variance of the optimum cover thickness is zero and it can be concluded that the optimum cover thickness is insensitive to all model inputs.

\subsubsection{Total Closure Cost}

The sensitivity analysis of total closure cost was performed by fitting a generalized boosted model (gbm) to the GoldSim model data (Ridgeway 2007). Complete details of the sensitivity analysis are presented in Appendix A2.

The gbm package returns the relative influence, which is the percentage of the regression model variance explained by adding the variable to the model. A value of 100 would indicate that 100 percent of the regression model variance is explained by that parameter.

The gbm results indicate that total closure cost is strongly sensitive to the cost estimate contingency and the construction cost escalation rate. Slight sensitivity to the infrastructure indirect rate is observed. The model is insensitive to the cost of health detriment. Total closure cost of the 92-ac LLWMU is strongly sensitive to the contingency rate (Table 3.13). When the time of closure is pushed farther in to the future, which is the case for the Northern Expansion Area, the most sensitive parameter becomes the escalation rate. Total closure cost of the Area 5 RWMS has approximately equal sensitivity to the contingency and escalation rate.

Table 3.13 Sensitivity analysis results for total closure costs with a 2.5-m closure cover.

\begin{tabular}{|c|c|c|}
\hline Model Result: Total Closure Cost & Parameter & Gbm Relative Influence \\
\hline \multirow{3}{*}{ 92-ac LLWMU, 2.5-m Closure Cover } & Contingency & 90 \\
\cline { 2 - 3 } & Escalation Rate & 4.2 \\
\cline { 2 - 3 } & Infrastructure Indirect Rate & 3.5 \\
\hline \multirow{2}{*}{$\begin{array}{c}\text { Northern Expansion Area, 2.5-m Closure } \\
\text { Cover }\end{array}$} & Escalation Rate & 61 \\
\cline { 2 - 3 } & Contingency & 36 \\
\cline { 2 - 3 } & Infrastructure Indirect Rate & 1.5 \\
\hline \multirow{3}{*}{ Area 5 RWMS, 2.5-m Closure Cover } & Escalation Rate & 50 \\
\cline { 2 - 3 } & Contingency & 46 \\
\cline { 2 - 3 } & Infrastructure Indirect Rate & 2.2 \\
\hline
\end{tabular}


It may seem unexpected that model uncertainty is dominated by cover construction costs rather than uncertainty in long-term site performance. Model sensitivity is a function of model structure and parameter distributions. The total closure cost model is most sensitive to construction cost parameters because construction costs exceed the cost of health detriment by orders of magnitude.

\subsection{DISCUSSION}

The total closure cost is contributed overwhelmingly by cover construction costs. The low collective doses are the result of the low probability of future settlement. A consequence of the low collective dose is that the optimization is insensitive to factors related to collective dose, including the monetary value of health detriment and the period of collective dose integration.

Although previous assessments had concluded that cover thickness was an important parameter affecting site performance, the present study finds a weak relationship between cover thickness and collective dose. PAs are required to assume that residents are always present at the site boundary. Residents are exposed to contaminants released to surface soil and the atmosphere by natural transport processes. Releases caused by natural transport processes are reduced by increasing cover thickness. Therefore, PA results indicate that increasing cover thickness will improve site performance by reducing offsite resident dose.

In contrast, the collective dose is calculated, assuming residents are located stochastically in time and space. The collective dose is dominated by the dose from comparatively rare onsite residents. Onsite resident dose is controlled predominately by exposure to contaminated borehole cuttings dumped by a water well driller. Collective dose is relatively insensitive to cover thickness, because the release of drill cuttings is independent of cover thickness. The exclusion of ${ }^{222} \mathrm{Rn}$ and its short-lived progeny in air from the dose calculation may also contribute to the insensitivity of collective dose to cover thickness.

The conclusion that onsite residents are the major source of collective dose suggests that deterring intruders and onsite residents may be more effective at reducing risk than increasing cover thickness. However, the low monetary value of the estimated collective dose suggests that only relatively inexpensive institutional controls would be cost effective.

It might also be argued that deterring intruders and onsite residents is outside the scope of DOE M 435.1-1 ALARA requirements because it does not optimize the release of radionuclides. 


\subsection{CONCLUSIONS}

The purpose of the cover optimization is to provide NNSA/NSO with information necessary to select a closure cover thickness for the Area 5 RWMS that maintains releases to the environment ALARA. The cost-benefit optimization evaluates five discrete cover thicknesses ranging from 2.5 to $4.5 \mathrm{~m}$ (8.2 to $15 \mathrm{ft})$. The optimization is performed for the 92-ac LLWMU, the Northern Expansion Area, and the Area 5 RWMS. The optimum cover thickness is shown to be the thickness with the minimum total closure cost.

The optimization constraints are that all applicable radiological regulatory requirements are met, and individual doses are a small fraction of background exposures. The five cover thicknesses evaluated meet the DOE M 435.1-1 PA/CA requirements and likely meet the requirements of 40 CFR 191 applied to the TRU waste in GCD boreholes. Individual dose among the most exposed subgroups is a small fraction of the dose from natural background sources. Therefore, it is concluded that the five cover options meet the constraints.

As noted in Section 1.4.3, a special analysis of TRU waste in T04C concluded that a 2.8-m (9.2-ft) thick cover is required to meet the 40 CFR 191.15 individual protection requirements. The limited quantity of TRU waste inadvertently disposed in T04C is not legally subject to the

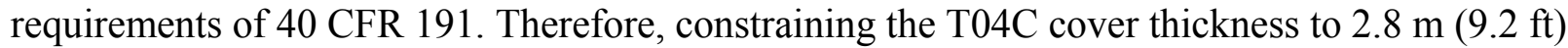
is considered optional. Of the special analysis dose estimate, 99 percent is due to LLW co-disposed in T04C. Consequently, it is likely that most Area 5 RWMS SLB disposal units would need a thicker cover to meet the 40 CFR 191.15 individual protection requirements. This conclusion is expected because the 40 CFR 191.15 requirements are more stringent than DOE M 435.1-1 in terms of the dose limit, compliance period, and point of compliance.

The total closure cost is a monotonically increasing function of cover thickness for all three disposal configurations. Cover construction costs are significantly greater than health detriment costs at all cover thicknesses. The optimum cover thickness over the range of options evaluated is $2.5 \mathrm{~m}(8.2-\mathrm{ft})$. All 2,000 model realizations produced the same result, indicating that there is high confidence that a $2.5-\mathrm{m}(8.2-\mathrm{ft})$ cover is optimal. The optimal cover thickness is insensitive to all parameter values, the monetary value of the health detriment, and the period of integration up to 10,000 years.

The cover optimization assumes that cover performance is unaffected by subsidence. The magnitude, timing, and consequences of subsidence remain an important source of uncertainty in the performance of the Area 5 RWMS. Selection of a thinner cover may require additional monitoring and research addressing subsidence. Plans for mitigating the consequences of subsidence may need additional consideration with the use of a significantly thinner cover. 
This Page Intentionally Left Blank 


\subsection{REFERENCES}

Barraclough, I. M., J. D. Robb, C. A. Robinson, K. R. Smith, and J. R. Cooper, 1996. The Use of Estimates of Collective Dose to the Public. J. of Radiological Protection 16: 73-80.

Blout, D. O., W. S. Birchfiel, D. P. Hammermeister, K. A. Zukosky, and K. D. Donnelson, 1995. Site Characterization Data from the Area 5 Science Boreholes, Nevada Test Site, Nye County, Nevada. Las Vegas, NV: Reynolds Electrical and Engineering Company, Inc. DOE/NV/11432--170.

Bechtel Nevada, 1998. Performance Assessment for the Area 5 Radioactive Waste Management Site at the Nevada Test Site, Nye County, Nevada. Las Vegas, NV. DOE/NV/11718--176, Rev. 2.1.

Bechtel Nevada, 2001a. Addendum 1, Performance Assessment for the Area 5 Radioactive Waste Management Site at the Nevada Test Site, Nye County, Nevada, Revaluation of the Chronic Inadvertent Human Intrusion Scenarios to Resolve the Disposal Authorization Statement Issues. Las Vegas, NV. DOE/NV/11718--176-ADD1.

Bechtel Nevada, 2001b. Composite Analysis for the Area 5 Radioactive Waste Management Site at the Nevada Test Site, Nye County, Nevada. Las Vegas, NV. DOE/NV/11718 - 594.

Bechtel Nevada, 2005. Integrated Closure and Monitoring Plan for the Area 3 and Area 5 Radioactive Waste Management Sites at the Nevada Test Site. Las Vegas, NV. DOE/NV/11718--449-REV2; 2005a.

Bechtel Nevada, 2006. Addendum 2 to the Performance Assessment for the Area 5 Radioactive Waste Management Site at the Nevada Test Site, Nye County, Nevada. Las Vegas, NV. DOE/NV/11718--176-ADD2.

Black, P., K. Black, L. Stahl, M. Hooten, T. Stockton, and D. Neptune, 2001. Assessing the Probability of Inadvertent Human Intrusion at the Nevada Test Site Radioactive Waste Management Sites, Vols. I and II. Los Alamos, MN: Neptune and Company, Inc. DOE/NV--593--Vol. I, II, March 2001.

BLS, see Bureau of Labor Statistics.

BN, see Bechtel Nevada.

Bureau of Labor Statistics, 2008. Consumer Price Index Inflation Calculator. Available online at: http://data.bls.gov/cgi-bin/cpicalc.pl, Accessed August 8, 2008.

CFR, see Code of Federal Regulations.

Clarke, R. H., 2001. Control of Low-Level Radiation Exposure: What is the Problem and How Can It Be Solved? Health Physics 80: 391-396. 
Cochran, J. R., W. E. Beyeler, D. A. Brosseau, L. H. Brush, T. J. Brown, B. Crowe, S. H. Conrad, P. A. Davis, T. Ehrhorn, T. Feeney, B. Fogleman, D. P. Gallegos, R. Haaker, E. Kalinina, L. L. Price, D. P. Thomas, and S. Wirth, 2001. Compliance Assessment Document for the Transuranic Wastes in the Greater Confinement Disposal Boreholes at the Nevada Test Site. Albuquerque, NM: Sandia National Laboratories, SAND2001-2977.

Code of Federal Regulations, Title 40, Part 191, 1993. "Environmental Radiation Protection Standards for Management and Disposal of Spent Nuclear Fuel, High-Level and Transuranic Radioactive Waste." Washington, DC: Office of the Federal Register.

de Rocquigny, E., N. Devictor, and S. Tarantola, 2008. Uncertainty in Industrial Practice: A Guide to Quantitative Uncertainty Management. West Sussex, England: John Wiley and Sons.

DOE, see U.S. Department of Energy.

DOE/NV, see U.S. Department of Energy, Nevada Operations Office.

Dunster, H. J., 2000. Collective Dose: Kill or Cure? J. of Radiological Protection 20: 3-4.

Eged, K., B. Kanyar, Z. Kis, T. Tatay, A. Ivady, and G. Volent, 2001. Determination and Use of the Monetary Values of the Averted Person-Sievert for Use in Radiation Protection Decisions in Hungary. Health Physics 80: 137-141.

Fairlie, I., and D. Sumner, 2000. In Defence of Collective Dose. J. of Radiological Protection 20: 9-19.

French, S., T. Bedford, and E. Atherton, 2005. Supporting ALARP Decision Making by Cost Benefit Analysis and Multiattribute Utility Theory. J. of Risk Research 8: 207-223.

Guenther, C. F., and C. Thein, 1997. Estimated Cost of Person-Sv Exposure. Health Physics 72: 204-221.

Hanley, N., 1992. Are There Environmental Limits to Cost Benefit Analysis? Environmental and Resource Economics 2: 33-59.

Hardeman, F., N. Pauwels, B. Van de Walle, P. Deboodt, and P. De Meester, 1998. The Monetary Value of the Person-Sievert: A Practical Approach in Case of Occupational Exposures. Health Physics 74: 330-336.

IAEA, see International Atomic Energy Agency.

ICRP, see International Commission on Radiological Protection.

International Atomic Energy Agency, 2001. Generic Models for Use in Assessing the Impact of Discharges of Radioactive Substances to the Environment. Vienna, Austria: International Atomic Energy Agency, Safety Report Series No. 19. 
International Commission on Radiological Protection, 1977. Recommendations of the International Commission on Radiological Protection. Pergamon Press: NY, ICRP Publication 26.

International Commission on Radiological Protection, 1983. Cost-Benefit Analysis in the Optimization of Radiation Protection. Pergamon Press: NY, ICRP Publication 37.

International Commission on Radiological Protection, 1991. 1990 Recommendations of the International Commission on Radiological Protection. Pergamon Press: NY, ICRP Publication 60.

International Commission on Radiological Protection, 2005. The Optimization of Radiological Protection: Broadening the Process. Draft for Consultation. Available online at http://www.icrp.org/docs/Optimisation_web_cons_draft 42 105 05.pdf Accessed January 8, 2009.

International Commission on Radiological Protection, 2007a. Draft Recommendations of the International Commission on Radiological Protection. Available online at http://www.icrp.org/docs/ICRP_Draft_Recommendations_12_January_2007.pdf, Accessed September 15, 2008.

International Commission on Radiological Protection, 2007b. Assessing Dose of the Representative Person for the Purposes of Radiation Protection of the Public and the Optimization of Radiological Protection: Broadening the Process. Elsevier Ltd.: Oxford, ICRP Publication 101.

Istok, J., D. O. Blout, L. Barker, K. R. Johnejack, and D. P. Hammermeister, 1994. Spatial Variability in Alluvium Properties at a Low-Level Nuclear Waste Site. Soil Science Society of Am. J. 58: 1040-1051.

Katona, T., B. Kanyar, K. Eged, Z. Kis, A. Nenyei, and R. Bodnar, 2003. The Monetary Value of the Averted Dose for Public Exposure Assessed by the Willingness to Pay. Health Physics 84: 594-598.

Lindell, B., 2000. On Collective Dose. J. of Radiological Protection 20: 1-2.

Morgan M. G., and M. Henrion, 1990. Uncertainty, a Guide to Dealing with Uncertainty in Quantitative Risk and Policy Analysis. New York, NY: Cambridge University Press.

National Council on Radiological Protection and Measurements, 1987. Ionizing Radiation Exposure of the Population of the United States. Bethesda, MD: NCRP Report No. 93.

National Council on Radiological Protection and Measurements, 1996. A Guide for Uncertainty Analysis in Dose and Risk Assessment Related to Environmental Contamination. Bethesda, MD: NCRP Commentary No. 14. 
National Security Technologies, LLC, 2007. 2006 Annual Summary Report for the Area 3 and Area 5 Radioactive Waste Management Sites at the Nevada Test Site, Nye County, Nevada. Las Vegas, NV. DOE/NV/25946--135.

National Security Technologies, LLC, 2008a. 2007 Annual Summary Report for the Area 3 and Area 5 Radioactive Waste Management Sites at the Nevada Test Site, Nye County, Nevada. Las Vegas, NV. DOE/NV/25946--346.

National Security Technologies, LLC, 2008b. 2007 Data Report: Goundwater Monitoring Program Area 5 Radioactive Waste Management Site. Las Vegas, NV. DOE/NV/25946--344.

National Security Technologies, LLC, 2008c. 2007 Waste Management Monitoring Report Area 3 and Area 5 Radioactive Waste Management Sites. Las Vegas, NV. DOE/NV/25946--490.

National Security Technologies, LLC, 2008d. Final Closure Cover for Area 5, Option 1. Las Vegas, NV. Cost Estimate 3213A, Rev. 0, September 2, 2008.

National Security Technologies, LLC, 2008e. Final Closure Cover for Area 5, Option 2. Las Vegas, NV. Cost Estimate 3213A, Rev. 0, September 2, 2008.

NCRP, see National Council on Radiological Protection and Measurements.

NRC, see U.S. Nuclear Regulatory Commission.

NSTec, see National Security Technologies, LLC.

REECo, see Reynolds Electrical and Engineering Company, Inc.

Reynolds Electrical and Engineering Company, Inc., 1993. Hydrogeologic Data for Science Trench Boreholes at the Area 5 Radioactive Waste Management Site, Nevada Test Site, Nye County, Nevada. Las Vegas, NV. DOE/NV/11432--32.

Reynolds Electrical and Engineering Company, Inc., 1994. Site Characterization and Monitoring Data from the Area 5 Pilot Wells, Nye County, Nevada. Las Vegas, NV. DOE/NV/11432--74.

Ridgeway, G., 2007. Generalized Boosted Models: A Guide to the GBM Package. Available online at http://cran.r-project.org/web/packages/gbm/vignettes/gbm.pdf, Accessed January 6, 2009.

Schneider, T., C. Schieber, L. Eeckhoudt, and C. Gollier, 1997. Economics of Radiation Protection: Equity Considerations. Theory and Decision 43: 241-251. 
Shott, G., L. E. Barker, S. E. Rawlinson, M. J. Sully, and B. A. Moore, 1998. Performance Assessment for the Area 5 Radioactive Waste Management Site at the Nevada Test Site, Nye County, Nevada, Rev. 2.1. Las Vegas, NV: Bechtel Nevada, DOE/NV/11718--176/UC-721.

Shott, G., V. Yucel, and L. Desotell, 2008. Special Analysis of Transuranic Waste in Trench T04C at the Area 5 Radioactive Waste Management Site, Nevada Test Site, Nye County Nevada. Las Vegas, NV: National Security Technologies, LLC, DOE/NV/25946--283.

Smith, K. R., A. P. Bexon, K. Sihra, J. R. Simmonds, J. Lochard, T. Schneider, B. Bataille, 2007. Guidance on the Calculation, Presentation, and Use of Collective Doses for Routine Discharges. Oxfordshire, United Kingdom: Health Protection Agency, Center for Radiation, Chemical, and Environmental Hazards, Radiation Protection 144.

U.S. Department of Energy, 1997. Applying the ALARA Process for Radiation Protection of the Public and Environmental Compliance with 10 CFR Part 834 and DOE 5400.5 ALARA Program Requirements, Volume 1. Washington, D.C. DOE-STD-ALARA1draft.

U.S. Department of Energy, 1999. DOE O 435.1, "Radioactive Waste Management." Washington, D.C.

U.S. Department of Energy, 2001. DOE M 435.1-1 Chg 1, "Radioactive Waste Management Manual." Washington, D.C.

U.S. Department of Energy, Nevada Operations Office, 1998. Consequences of Subsidence for the Area 3 and Area 5 Radioactive Waste Management Sites, Nevada Test Site. Las Vegas, NV. DOE/NV--502.

U.S. Environmental Protection Agency, 1997. Exposure Factors Handbook. Available online at: http://www.epa.gov/ncea/efh/pdfs/efh-front-gloss.pdf, Accessed January 26, 2009.

U.S. Nuclear Regulatory Commission, 1995. Reassessment of the NRC's Dollar per Person-Rem Conversion Factor Policy. Washington, D.C. NUREG--1530.

Walvoord, M. A., M. A. Plummer, F. M. Philips, and A. V. Wolfsberg. 2002. Deep Arid System Hydrodynamics, 1: Equilibrium States and Response Times in Thick Desert Vadose Zones. Water Resources Res. 38(12): 44-1-44-15. 
This Page Intentionally Left Blank 


\section{APPENDIX A}

\section{A1 Area 5 RWMS Inventories}

Two closure covers are planned for the Area 5 Radioactive Waste Management Site (RWMS). The first cover for the 92-acre (ac) Low-Level Waste Management Unit (LLWMU) will be constructed in 2011. The second cover for the Northern Expansion Area is planned for 2028. The optimization of cover thickness is performed for the 92-ac LLWMU, the Northern Expansion Area, and the total Area 5 RWMS.

Each optimization study requires development of the appropriate inventory. In addition, because the optimization includes a constraint that all applicable regulatory requirements must be met, specialized inventories must be developed for comparison with the performance assessment (PA) and composite analysis (CA) requirements.

Table A1.1 lists each of the analyses performed in the optimization and the necessary inventories. Each of the inventories was calculated with the A5 Inventory v2.104 GoldSim model using database disposal records through the end of FY 2008.

Table A1.1 Summary of analyses and inventories used for each analysis

\begin{tabular}{|c|c|c|c|c|c|c|c|c|c|c|}
\hline \multirow[b]{2}{*}{ Analysis } & \multicolumn{10}{|c|}{ Inventory } \\
\hline & 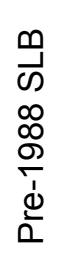 & 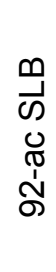 & 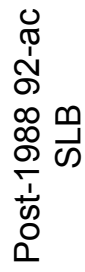 & 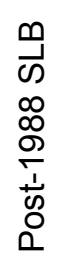 & 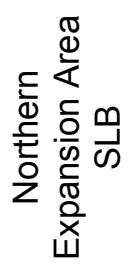 & 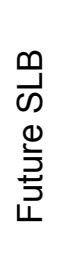 & 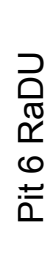 & 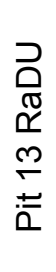 & $\begin{array}{l}0 \\
0 \\
0 \\
\infty \\
0 \\
0 \\
\frac{0}{d} \\
\dot{d}\end{array}$ & $\begin{array}{l}0 \\
0 \\
0 \\
0 \\
0 \\
0 \\
0 \\
\vdots \\
0 \\
0 \\
0\end{array}$ \\
\hline 92-ac LLWMU PA Compliance & & & $\mathrm{x}$ & & & & $\mathrm{X}$ & & & $\mathrm{X}$ \\
\hline 92-ac LLWMU Optimization & & $\mathrm{X}$ & & & & & $\mathrm{X}$ & & $\mathrm{X}$ & $\mathrm{X}$ \\
\hline Northern Expansion Area PA Compliance & & & & & $\mathrm{X}$ & $\mathrm{X}$ & & $\mathrm{X}$ & & \\
\hline Northern Expansion Area Optimization & & & & & $\mathrm{X}$ & $\mathrm{X}$ & & $\mathrm{X}$ & & \\
\hline Area 5 RWMS PA Compliance & & & & $\mathrm{X}$ & & $\mathrm{X}$ & $\mathrm{X}$ & $\mathrm{X}$ & & $\mathrm{X}$ \\
\hline Area 5 RWMS CA Compliance & $\mathrm{X}$ & & & $\mathrm{X}$ & & $\mathrm{X}$ & $\mathrm{X}$ & $\mathrm{X}$ & $\mathrm{X}$ & $\mathrm{X}$ \\
\hline Area 5 RWMS Optimization & $\mathrm{X}$ & & & $\mathrm{X}$ & & $\mathrm{X}$ & $\mathrm{X}$ & $\mathrm{X}$ & $\mathrm{X}$ & $\mathrm{X}$ \\
\hline
\end{tabular}

The routine Area 5 RWMS inventories were estimated from 500 Latin hypercube sampling (LHS) realizations. The simulated inventories for all radionuclides were well fit by lognormal distributions and are summarized in Tables A1.2 through A1.4 by their geometric means and geometric standard deviations. 
Table A1.2 Geometric mean and standard deviation of 500 LHS realizations of the pre-1988, post1988, and future SLB inventories on October 1, 2028

\begin{tabular}{|c|c|c|c|c|c|c|}
\hline \multirow[b]{2}{*}{ Nuclide } & \multicolumn{2}{|c|}{ Pre-1988 SLB } & \multicolumn{2}{|c|}{ Post-1988 SLB } & \multicolumn{2}{|c|}{ Future SLB } \\
\hline & $\begin{array}{l}\text { Geometric } \\
\text { Mean (Bq) }\end{array}$ & $\begin{array}{l}\text { Geometric } \\
\text { Standard } \\
\text { Deviation }\end{array}$ & $\begin{array}{l}\text { Geometric } \\
\text { Mean }(\mathrm{Bq})\end{array}$ & $\begin{array}{l}\text { Geometric } \\
\text { Standard } \\
\text { Deviation }\end{array}$ & $\begin{array}{l}\text { Geometric } \\
\text { Mean (Bq) }\end{array}$ & $\begin{array}{l}\text { Geometric } \\
\text { Standard } \\
\text { Deviation }\end{array}$ \\
\hline $\mathrm{H}-3$ & $3.2 \mathrm{E}+16$ & 1.86 & $3.1 \mathrm{E}+16$ & 1.70 & $3.2 \mathrm{E}+16$ & 2.54 \\
\hline C-14 & $2.6 E+11$ & 2.01 & $9.2 E+11$ & 1.91 & $1.6 \mathrm{E}+11$ & 2.83 \\
\hline Al-26 & $8.2 E+06$ & 2.08 & $3.0 \mathrm{E}+04$ & 2.95 & Negligible & \\
\hline $\mathrm{Cl}-36$ & $4.7 \mathrm{E}+10$ & 2.06 & $1.9 \mathrm{E}+08$ & 2.56 & $1.3 \mathrm{E}+06$ & 8.42 \\
\hline Ar-39 & $2.1 \mathrm{E}+11$ & 2.09 & $7.9 E+08$ & 2.75 & Negligible & \\
\hline $\mathrm{K}-40$ & $1.2 \mathrm{E}+10$ & 2.02 & $1.3 E+10$ & 1.68 & $3.5 \mathrm{E}+09$ & 3.18 \\
\hline $\mathrm{Ca}-41$ & $3.3 E+11$ & 2.07 & $1.2 \mathrm{E}+09$ & 2.67 & $4.0 \mathrm{E}+04$ & 186 \\
\hline Co-60 & $1.9 E+12$ & 2.81 & $1.8 E+14$ & 2.20 & $4.2 E+13$ & 6.41 \\
\hline $\mathrm{Ni}-59$ & $8.8 \mathrm{E}+09$ & 2.04 & $8.6 \mathrm{E}+11$ & 2.06 & $6.3 E+10$ & 9.96 \\
\hline $\mathrm{Ni}-63$ & $6.6 \mathrm{E}+11$ & 2.09 & $6.7 E+13$ & 2.09 & $6.5 \mathrm{E}+12$ & 6.91 \\
\hline Se-79 & Negligible & & $3.2 \mathrm{E}+12$ & 2.23 & $7.3 \mathrm{E}+10$ & 175 \\
\hline $\mathrm{Kr}-85$ & $4.0 \mathrm{E}+11$ & 2.86 & $4.5 \mathrm{E}+09$ & 1.97 & $7.0 \mathrm{E}+08$ & 4.60 \\
\hline Sr-90 & $1.6 \mathrm{E}+15$ & 3.66 & $1.5 E+16$ & 2.33 & $6.5 \mathrm{E}+14$ & 15.3 \\
\hline Zr-93 & $1.1 \mathrm{E}+09$ & 2.04 & $7.1 \mathrm{E}+07$ & 2.17 & $2.6 \mathrm{E}+06$ & 30.9 \\
\hline $\mathrm{Nb}-93 \mathrm{~m}$ & $1.1 \mathrm{E}+11$ & 2.09 & $8.9 E+08$ & 2.62 & $4.5 \mathrm{E}+06$ & 9.53 \\
\hline $\mathrm{Nb}-94$ & $2.8 E+11$ & 2.13 & $1.7 E+11$ & 2.65 & $2.3 E+09$ & 34.9 \\
\hline Tc-99 & $1.2 \mathrm{E}+13$ & 2.61 & $3.5 E+14$ & 1.88 & $3.8 \mathrm{E}+13$ & 3.88 \\
\hline $\mathrm{Pd}-107$ & $5.1 \mathrm{E}+07$ & 2.02 & $7.1 \mathrm{E}+05$ & 1.97 & $2.0 \mathrm{E}+04$ & 15.5 \\
\hline $\mathrm{Ag}-108 \mathrm{~m}$ & Negligible & & $2.5 E+11$ & 2.54 & $4.4 \mathrm{E}+08$ & 204 \\
\hline $\mathrm{Cd}-113 \mathrm{~m}$ & $9.3 E+10$ & 2.10 & $2.8 \mathrm{E}+10$ & 2.50 & $2.3 E+08$ & 98.8 \\
\hline Sn-121m & $2.5 \mathrm{E}+12$ & 2.09 & $1.1 \mathrm{E}+10$ & 2.74 & $5.5 \mathrm{E}+04$ & 20.5 \\
\hline Sn-126 & $4.9 E+08$ & 2.02 & $3.5 E+10$ & 2.10 & $1.7 E+09$ & 19.7 \\
\hline $\mathrm{I}-129$ & $3.6 \mathrm{E}+07$ & 2.01 & $3.2 \mathrm{E}+09$ & 1.68 & $6.2 \mathrm{E}+08$ & 3.35 \\
\hline Ba-133 & $1.4 \mathrm{E}+08$ & 3.62 & 1.1E+09 & 2.24 & $6.6 \mathrm{E}+08$ & 8.89 \\
\hline Cs-135 & $8.9 E+08$ & 2.03 & $3.2 \mathrm{E}+07$ & 2.15 & 7.1E+05 & 20.9 \\
\hline Cs-137 & $2.7 E+15$ & 4.12 & $7.5 E+14$ & 2.20 & $7.2 \mathrm{E}+13$ & 4.76 \\
\hline Pm-145 & Negligible & & $7.0 \mathrm{E}+04$ & 2.63 & $4.3 \mathrm{E}+03$ & 46.5 \\
\hline $\mathrm{Pm}-146$ & Negligible & & $1.4 \mathrm{E}+05$ & 1.88 & $5.0 \mathrm{E}+04$ & 7.04 \\
\hline Sm-151 & $1.0 \mathrm{E}+12$ & 2.03 & $1.8 \mathrm{E}+10$ & 1.98 & $7.0 \mathrm{E}+08$ & 8.57 \\
\hline Eu-150 & $3.7 E+11$ & 2.20 & 1.6E+09 & 3.36 & 6.7E-01 & 26.1 \\
\hline Eu-152 & $2.3 E+12$ & 2.57 & $4.4 \mathrm{E}+13$ & 2.23 & $2.8 \mathrm{E}+12$ & 16.5 \\
\hline Eu-154 & $3.0 \mathrm{E}+11$ & 2.42 & $3.4 \mathrm{E}+13$ & 2.13 & $2.8 \mathrm{E}+12$ & 30.5 \\
\hline Gd-148 & Negligible & & $1.4 \mathrm{E}+04$ & 1.98 & $3.5 \mathrm{E}+03$ & 5.18 \\
\hline Ho-166m & $1.1 \mathrm{E}+10$ & 2.06 & $4.1 \mathrm{E}+07$ & 2.77 & $1.7 \mathrm{E}+00$ & 15.2 \\
\hline $\mathrm{Bi}-207$ & $4.5 \mathrm{E}+05$ & 3.94 & $1.1 \mathrm{E}+07$ & 2.19 & $9.8 \mathrm{E}+05$ & 8.33 \\
\hline $\mathrm{Pb}-210$ & $8.6 \mathrm{E}+11$ & 3.40 & $5.4 \mathrm{E}+10$ & 1.51 & $2.6 \mathrm{E}+10$ & 2.70 \\
\hline
\end{tabular}




\begin{tabular}{|c|c|c|c|c|c|c|}
\hline \multirow[b]{2}{*}{ Nuclide } & \multicolumn{2}{|c|}{ Pre-1988 SLB } & \multicolumn{2}{|c|}{ Post-1988 SLB } & \multicolumn{2}{|c|}{ Future SLB } \\
\hline & $\begin{array}{l}\text { Geometric } \\
\text { Mean }(\mathrm{Bq})\end{array}$ & $\begin{array}{l}\text { Geometric } \\
\text { Standard } \\
\text { Deviation }\end{array}$ & $\begin{array}{l}\text { Geometric } \\
\text { Mean }(\mathrm{Bq})\end{array}$ & $\begin{array}{l}\text { Geometric } \\
\text { Standard } \\
\text { Deviation }\end{array}$ & $\begin{array}{l}\text { Geometric } \\
\text { Mean }(\mathrm{Bq})\end{array}$ & $\begin{array}{l}\text { Geometric } \\
\text { Standard } \\
\text { Deviation }\end{array}$ \\
\hline Ra-226 & $1.1 \mathrm{E}+12$ & 3.41 & $7.3 E+10$ & 1.55 & $4.1 \mathrm{E}+10$ & 2.68 \\
\hline Ra-228 & $4.8 E+10$ & 2.28 & $6.4 \mathrm{E}+11$ & 1.52 & $2.7 E+11$ & 2.35 \\
\hline Ac-227 & $1.2 \mathrm{E}+10$ & 2.05 & $5.1 \mathrm{E}+09$ & 1.50 & $1.4 \mathrm{E}+10$ & 6.05 \\
\hline Th-228 & $6.5 \mathrm{E}+10$ & 2.03 & $2.2 E+12$ & 1.81 & $4.9 E+11$ & 2.39 \\
\hline Th-229 & $1.5 \mathrm{E}+08$ & 2.33 & $5.5 E+11$ & 2.08 & $2.5 E+10$ & 7.56 \\
\hline Th-230 & $4.3 E+10$ & 1.87 & $2.5 E+11$ & 1.64 & $1.2 \mathrm{E}+11$ & 3.27 \\
\hline Th-232 & $4.9 E+10$ & 2.28 & $6.7 E+11$ & 1.51 & $3.3 E+11$ & 2.32 \\
\hline $\mathrm{Pa}-231$ & $7.3 E+09$ & 1.91 & $8.6 \mathrm{E}+09$ & 1.56 & $1.9 E+09$ & 2.03 \\
\hline U-232 & $1.1 \mathrm{E}+10$ & 2.08 & $1.4 \mathrm{E}+12$ & 2.26 & $1.2 \mathrm{E}+11$ & 4.91 \\
\hline $\mathrm{U}-233$ & $3.2 \mathrm{E}+10$ & 2.41 & $1.1 \mathrm{E}+14$ & 2.62 & $3.9 \mathrm{E}+12$ & 11.5 \\
\hline U-234 & $8.4 \mathrm{E}+13$ & 2.04 & $9.7 E+13$ & 1.44 & $3.7 E+13$ & 1.94 \\
\hline U-235 & $3.4 \mathrm{E}+12$ & 2.07 & $4.6 \mathrm{E}+12$ & 1.44 & $2.1 \mathrm{E}+12$ & 1.88 \\
\hline U-236 & $1.1 \mathrm{E}+12$ & 3.02 & $2.8 E+12$ & 1.55 & $6.2 E+11$ & 2.73 \\
\hline $\mathrm{U}-238$ & $9.1 \mathrm{E}+13$ & 2.18 & $2.0 \mathrm{E}+14$ & 1.48 & $9.5 \mathrm{E}+13$ & 1.84 \\
\hline Np-237 & $2.3 E+11$ & 1.99 & $1.4 \mathrm{E}+11$ & 1.72 & $2.1 \mathrm{E}+10$ & 2.90 \\
\hline Pu-238 & $6.7 \mathrm{E}+12$ & 1.91 & $6.4 \mathrm{E}+12$ & 1.63 & $2.5 E+12$ & 2.05 \\
\hline Pu-239 & $1.3 E+13$ & 1.96 & $1.2 E+13$ & 1.64 & $3.4 \mathrm{E}+12$ & 2.03 \\
\hline Pu-240 & $3.0 \mathrm{E}+12$ & 1.91 & $5.3 E+12$ & 1.84 & $1.0 \mathrm{E}+12$ & 2.55 \\
\hline Pu-241 & $3.6 \mathrm{E}+12$ & 1.95 & $3.3 E+13$ & 2.02 & $8.0 E+12$ & 2.92 \\
\hline Pu-242 & $6.8 \mathrm{E}+08$ & 1.92 & $4.1 \mathrm{E}+11$ & 2.67 & $1.8 \mathrm{E}+10$ & 12.8 \\
\hline Pu-244 & $4.9 \mathrm{E}+09$ & 3.99 & $4.0 \mathrm{E}+04$ & 2.53 & $1.6 \mathrm{E}+03$ & 10.6 \\
\hline Am-241 & $4.2 E+12$ & 1.91 & $7.7 E+12$ & 1.69 & $1.4 \mathrm{E}+12$ & 2.34 \\
\hline Am-242m & Negligible & & $1.5 \mathrm{E}+09$ & 1.82 & $2.1 \mathrm{E}+08$ & 4.79 \\
\hline Am-243 & $3.9 \mathrm{E}+08$ & 2.70 & $3.8 E+10$ & 2.19 & $2.8 E+09$ & 5.84 \\
\hline $\mathrm{Cm}-243$ & $4.6 \mathrm{E}+09$ & 2.83 & $3.2 E+08$ & 1.93 & $5.9 E+07$ & 3.57 \\
\hline $\mathrm{Cm}-244$ & $7.9 \mathrm{E}+10$ & 3.03 & $5.5 \mathrm{E}+11$ & 1.89 & $1.1 \mathrm{E}+11$ & 3.94 \\
\hline $\mathrm{Cm}-245$ & $9.9 \mathrm{E}+04$ & 3.72 & $4.9 \mathrm{E}+11$ & 2.02 & $2.1 \mathrm{E}+10$ & 15.4 \\
\hline $\mathrm{Cm}-246$ & $6.6 \mathrm{E}+04$ & 3.26 & $8.4 E+10$ & 2.18 & $3.3 E+09$ & 19.5 \\
\hline $\mathrm{Cm}-247$ & Negligible & & $1.0 \mathrm{E}+03$ & 2.40 & $2.2 \mathrm{E}+01$ & 97.4 \\
\hline Cm-248 & $6.3 E+04$ & 3.67 & $2.4 \mathrm{E}+05$ & 2.61 & $8.3 E+07$ & 3.60 \\
\hline Cf-249 & Negligible & & $1.0 \mathrm{E}+08$ & 2.01 & $1.2 \mathrm{E}+07$ & 5.12 \\
\hline Cf-250 & $2.2 E+05$ & 2.85 & $1.0 \mathrm{E}+05$ & 2.74 & $1.9 E+03$ & 26.6 \\
\hline Cf-251 & Negligible & & $6.4 \mathrm{E}+07$ & 2.41 & $2.6 \mathrm{E}+06$ & 25.1 \\
\hline Total & $3.7 E+16$ & & $4.8 E+16$ & & $3.3 E+16$ & \\
\hline
\end{tabular}

Negligible - Inventory less than $37 \mathrm{~Bq}$ 
Table A1.3 Geometric mean and standard deviation of 500 LHS realizations of the Pit 6 and Pit 13 RaDU inventories on October 1, 2028

\begin{tabular}{|c|c|c|c|c|c|c|}
\hline \multirow[b]{2}{*}{ Nuclide } & \multicolumn{2}{|c|}{ P06UA (Upper Cell) } & \multicolumn{2}{|c|}{ P06U (Lower Cell) RaDU } & \multicolumn{2}{|c|}{ P13U RaDU } \\
\hline & $\begin{array}{l}\text { Geometric } \\
\text { Mean }(\mathrm{Bq})\end{array}$ & $\begin{array}{l}\text { Geometric } \\
\text { Standard } \\
\text { Deviation }\end{array}$ & $\begin{array}{l}\text { Geometric } \\
\text { Mean }(\mathrm{Bq})\end{array}$ & $\begin{array}{l}\text { Geometric } \\
\text { Standard } \\
\text { Deviation }\end{array}$ & $\begin{array}{l}\text { Geometric } \\
\text { Mean }(\mathrm{Bq})\end{array}$ & $\begin{array}{l}\text { Geometric } \\
\text { Standard } \\
\text { Deviation }\end{array}$ \\
\hline $\mathrm{H}-3$ & $9.8 \mathrm{E}+11$ & 2.68 & Negligible & & $1.3 \mathrm{E}+09$ & 2.44 \\
\hline $\mathrm{K}-40$ & $8.9 E+02$ & 2.64 & Negligible & & $3.6 \mathrm{E}+03$ & 2.90 \\
\hline Co-60 & $3.6 \mathrm{E}+02$ & 2.51 & Negligible & & $5.7 \mathrm{E}+06$ & 2.62 \\
\hline $\mathrm{Ni}-63$ & Negligible & & Negligible & & $4.5 \mathrm{E}+07$ & 2.59 \\
\hline Sr-90 & $3.8 \mathrm{E}+07$ & 2.48 & $1.8 \mathrm{E}+07$ & 2.64 & $5.3 E+09$ & 2.70 \\
\hline Tc-99 & $5.8 \mathrm{E}+08$ & 2.66 & $1.1 \mathrm{E}+09$ & 2.74 & $1.4 \mathrm{E}+10$ & 2.09 \\
\hline Sn-126 & Negligible & & Negligible & & $1.3 \mathrm{E}+07$ & 2.77 \\
\hline $\mathrm{I}-129$ & 3.4E-02 & 2.70 & Negligible & & Negligible & \\
\hline $\mathrm{Ba}-133$ & $3.8 \mathrm{E}+04$ & 2.81 & Negligible & & Negligible & \\
\hline Cs-135 & $0.0 \mathrm{E}+00$ & 1.01 & Negligible & & Negligible & \\
\hline Cs-137 & $3.2 E+08$ & 2.65 & Negligible & & $7.2 \mathrm{E}+09$ & 2.65 \\
\hline Eu-152 & $3.3 \mathrm{E}+05$ & 2.75 & Negligible & & $9.5 \mathrm{E}+06$ & 2.68 \\
\hline Eu-154 & Negligible & & Negligible & & $1.3 \mathrm{E}+07$ & 2.66 \\
\hline Gd-152 & 2.3E-08 & 2.75 & Negligible & & 7.6E-07 & 2.68 \\
\hline $\mathrm{Pb}-210$ & $6.4 \mathrm{E}+07$ & 2.55 & $6.9 E+09$ & 1.69 & $6.8 \mathrm{E}+10$ & 1.69 \\
\hline Ra-226 & $1.2 \mathrm{E}+08$ & 2.46 & $1.9 \mathrm{E}+10$ & 1.70 & $1.4 \mathrm{E}+11$ & 1.70 \\
\hline Ra-228 & $1.1 \mathrm{E}+09$ & 2.60 & $6.0 \mathrm{E}+12$ & 1.60 & $5.5 \mathrm{E}+12$ & 1.06 \\
\hline Ac-227 & $9.9 \mathrm{E}+04$ & 1.96 & $2.3 E+06$ & 1.93 & $1.6 \mathrm{E}+05$ & 2.44 \\
\hline Th-228 & $1.1 \mathrm{E}+09$ & 2.60 & $5.9 \mathrm{E}+12$ & 1.60 & $5.4 \mathrm{E}+12$ & 1.06 \\
\hline Th-229 & $1.5 \mathrm{E}+04$ & 2.70 & $5.2 E+09$ & 2.17 & $1.8 \mathrm{E}+02$ & 2.43 \\
\hline Th-230 & $9.4 \mathrm{E}+08$ & 2.36 & $1.5 \mathrm{E}+12$ & 1.72 & $1.8 \mathrm{E}+12$ & 2.56 \\
\hline Th-232 & $1.1 \mathrm{E}+09$ & 2.61 & $6.1 \mathrm{E}+12$ & 1.61 & $5.9 \mathrm{E}+12$ & 1.06 \\
\hline $\mathrm{Pa}-231$ & $3.2 \mathrm{E}+05$ & 1.95 & $6.1 \mathrm{E}+06$ & 1.94 & $5.6 \mathrm{E}+05$ & 2.43 \\
\hline U-232 & Negligible & & Negligible & & $1.6 \mathrm{E}+08$ & 2.68 \\
\hline U-233 & $6.3 \mathrm{E}+06$ & 2.70 & $2.0 \mathrm{E}+12$ & 2.16 & $1.6 \mathrm{E}+05$ & 2.42 \\
\hline U-234 & $1.5 \mathrm{E}+10$ & 2.05 & $1.8 \mathrm{E}+11$ & 1.94 & $9.9 \mathrm{E}+09$ & 2.08 \\
\hline U-235 & $6.0 \mathrm{E}+08$ & 1.94 & $9.1 \mathrm{E}+09$ & 1.94 & $1.1 \mathrm{E}+09$ & 2.42 \\
\hline U-236 & $9.5 \mathrm{E}+08$ & 2.15 & $1.9 \mathrm{E}+08$ & 2.16 & $4.9 E+08$ & 2.67 \\
\hline U-238 & $3.1 \mathrm{E}+10$ & 1.90 & $2.1 \mathrm{E}+11$ & 1.86 & $1.0 \mathrm{E}+11$ & 2.42 \\
\hline $\mathrm{Np}-237$ & $1.2 \mathrm{E}+08$ & 2.55 & $7.9 \mathrm{E}+05$ & 2.75 & $1.6 \mathrm{E}+09$ & 2.42 \\
\hline Pu-238 & $1.1 E+09$ & 1.96 & $1.3 E+10$ & 1.94 & $3.3 E+08$ & 2.51 \\
\hline Pu-239 & $5.6 \mathrm{E}+10$ & 1.81 & $3.3 E+06$ & 2.23 & $8.4 \mathrm{E}+09$ & 2.15 \\
\hline Pu-240 & $1.2 \mathrm{E}+10$ & 1.83 & Negligible & & $3.9 \mathrm{E}+07$ & 2.53 \\
\hline $\mathrm{Pu}-241$ & $2.1 \mathrm{E}+10$ & 1.94 & $1.2 \mathrm{E}+10$ & 2.14 & $5.0 \mathrm{E}+09$ & 2.71 \\
\hline Pu-242 & $1.1 \mathrm{E}+06$ & 1.86 & Negligible & & Negligible & \\
\hline Am-241 & $1.1 \mathrm{E}+10$ & 1.71 & $1.1 \mathrm{E}+09$ & 2.15 & $1.3 E+09$ & 2.18 \\
\hline
\end{tabular}




\begin{tabular}{|c|c|c|c|c|c|c|}
\hline \multirow{2}{*}{ Nuclide } & \multicolumn{2}{|c|}{ P06UA (Upper Cell) } & P06U (Lower Cell) RaDU & \multicolumn{2}{c|}{ P13U RaDU } \\
\cline { 2 - 7 } & $\begin{array}{c}\text { Geometric } \\
\text { Mean (Bq) }\end{array}$ & $\begin{array}{c}\text { Geometric } \\
\text { Standard } \\
\text { Deviation }\end{array}$ & $\begin{array}{c}\text { Geometric } \\
\text { Mean (Bq) }\end{array}$ & $\begin{array}{c}\text { Geometric } \\
\text { Standard } \\
\text { Deviation }\end{array}$ & $\begin{array}{c}\text { Geometric } \\
\text { Mean (Bq) }\end{array}$ & $\begin{array}{c}\text { Standard } \\
\text { Deviation }\end{array}$ \\
\hline Cm-244 & $7.3 \mathrm{E}+01$ & 2.78 & Negligible & & Negligible & \\
\hline Total & $1.1 \mathrm{E}+12$ & & $2.2 \mathrm{E}+13$ & & $1.9 \mathrm{E}+13$ & \\
\hline
\end{tabular}

Table A1.4 Geometric mean and standard deviation of 500 LHS realizations of the GCD inventories on October 1, 2028

\begin{tabular}{|c|c|c|c|c|}
\hline \multirow[b]{2}{*}{ Nuclide } & \multicolumn{2}{|c|}{ Pre-1988 GCD } & \multicolumn{2}{|c|}{ Post-1988 GCD } \\
\hline & $\begin{array}{c}\text { Geometric Mean } \\
(\mathrm{Bq})\end{array}$ & $\begin{array}{c}\text { Geometric Standard } \\
\text { Deviation }\end{array}$ & $\begin{array}{c}\text { Geometric Mean } \\
(\mathrm{Bq})\end{array}$ & $\begin{array}{c}\text { Geometric Standard } \\
\text { Deviation }\end{array}$ \\
\hline $\mathrm{H}-3$ & $2.1 \mathrm{E}+16$ & 2.59 & $1.7 E+14$ & 2.66 \\
\hline C-14 & $6.4 \mathrm{E}+04$ & 3.01 & Negligible & \\
\hline $\mathrm{Cl}-36$ & $1.4 \mathrm{E}+04$ & 3.01 & Negligible & \\
\hline Ar-39 & $6.3 E+04$ & 3.10 & Negligible & \\
\hline $\mathrm{K}-40$ & $3.6 \mathrm{E}+03$ & 2.89 & Negligible & \\
\hline Ca-41 & $9.5 \mathrm{E}+04$ & 3.03 & Negligible & \\
\hline Co-60 & $7.8 \mathrm{E}+11$ & 2.62 & Negligible & \\
\hline $\mathrm{Ni}-59$ & $2.5 E+03$ & 2.98 & Negligible & \\
\hline $\mathrm{Ni}-63$ & $2.1 \mathrm{E}+05$ & 3.03 & Negligible & \\
\hline $\mathrm{Kr}-85$ & $5.6 \mathrm{E}+04$ & 2.88 & Negligible & \\
\hline Sr-90 & $4.8 \mathrm{E}+15$ & 4.09 & $7.9 \mathrm{E}+07$ & 5.08 \\
\hline Zr-93 & $3.4 \mathrm{E}+02$ & 2.90 & Negligible & \\
\hline $\mathrm{Nb}-93 \mathrm{~m}$ & $5.7 \mathrm{E}+04$ & 3.02 & Negligible & \\
\hline $\mathrm{Nb}-94$ & $7.8 \mathrm{E}+04$ & 3.04 & Negligible & \\
\hline Tc-99 & $6.7 E+09$ & 3.65 & $4.5 \mathrm{E}+09$ & 5.04 \\
\hline Cd-113m & $5.1 E+04$ & 3.13 & Negligible & \\
\hline Sn-121m & $8.9 \mathrm{E}+05$ & 3.08 & Negligible & \\
\hline Cs-137 & $2.6 \mathrm{E}+14$ & 3.62 & Negligible & \\
\hline Sm-151 & $3.4 \mathrm{E}+05$ & 2.90 & Negligible & \\
\hline Eu-150 & $1.3 \mathrm{E}+05$ & 3.43 & Negligible & \\
\hline Eu-152 & $4.0 \mathrm{E}+05$ & 2.97 & Negligible & \\
\hline Eu-154 & $8.3 E+04$ & 2.96 & Negligible & \\
\hline Gd-152 & $9.8 \mathrm{E}-08$ & 2.97 & Negligible & \\
\hline Ho-166m & $3.2 \mathrm{E}+03$ & 3.10 & Negligible & \\
\hline $\mathrm{Pb}-210$ & $2.3 \mathrm{E}+12$ & 3.98 & $3.5 \mathrm{E}+04$ & 2.57 \\
\hline $\mathrm{Ra}-226$ & $3.0 \mathrm{E}+12$ & 3.98 & $1.1 \mathrm{E}+05$ & 2.57 \\
\hline Ra-228 & $8.1 \mathrm{E}+08$ & 3.99 & $2.4 \mathrm{E}-08$ & 4.94 \\
\hline Ac-227 & $7.3 \mathrm{E}+10$ & 3.95 & $4.9 \mathrm{E}+05$ & 2.69 \\
\hline Th-228 & $8.1 \mathrm{E}+08$ & 3.99 & $2.0 \mathrm{E}-08$ & 4.94 \\
\hline Th-230 & $5.4 \mathrm{E}+07$ & 3.08 & $1.3 \mathrm{E}+07$ & 2.57 \\
\hline Th-232 & $8.2 E+08$ & 3.99 & $3.5 \mathrm{E}-08$ & 4.94 \\
\hline
\end{tabular}




\begin{tabular}{|c|c|c|c|c|}
\hline & \multicolumn{2}{|c|}{ Pre-1988 GCD } & \multicolumn{2}{c|}{ Post-1988 GCD } \\
\cline { 2 - 5 } Nuclide & $\begin{array}{c}\text { Geometric Mean } \\
(\mathbf{B q})\end{array}$ & $\begin{array}{c}\text { Geometric Standard } \\
\text { Deviation }\end{array}$ & $\begin{array}{c}\text { Geometric Mean } \\
\text { (Bq) }\end{array}$ & $\begin{array}{c}\text { Geometric Standard } \\
\text { Deviation }\end{array}$ \\
\hline Pa-231 & $4.6 \mathrm{E}+06$ & 3.03 & $1.1 \mathrm{E}+06$ & 2.69 \\
\hline U-232 & $3.8 \mathrm{E}+03$ & 3.01 & Negligible & 2.52 \\
\hline U-233 & $4.0 \mathrm{E}+04$ & 2.09 & $2.3 \mathrm{E}+04$ & 2.57 \\
\hline U-234 & $1.3 \mathrm{E}+11$ & 3.06 & $3.6 \mathrm{E}+10$ & 2.69 \\
\hline U-235 & $5.0 \mathrm{E}+09$ & 3.02 & $1.4 \mathrm{E}+09$ & 4.94 \\
\hline U-236 & $3.4 \mathrm{E}+08$ & 3.84 & Negligible & 2.52 \\
\hline U-238 & $3.3 \mathrm{E}+10$ & 3.12 & $6.7 \mathrm{E}+10$ & 2.52 \\
\hline Np-237 & $2.4 \mathrm{E}+08$ & 2.10 & $1.3 \mathrm{E}+08$ & 4.94 \\
\hline Pu-238 & $3.1 \mathrm{E}+11$ & 2.87 & $2.6 \mathrm{E}+06$ & 4.98 \\
\hline Pu-239 & $1.6 \mathrm{E}+13$ & 2.94 & $1.5 \mathrm{E}+08$ & 4.94 \\
\hline Pu-240 & $3.8 \mathrm{E}+12$ & 2.84 & $3.1 \mathrm{E}+07$ & 5.17 \\
\hline Pu-241 & $4.3 \mathrm{E}+12$ & 3.14 & $4.3 \mathrm{E}+07$ & \\
\hline Pu-242 & $3.6 \mathrm{E}+08$ & 2.86 & Negligible & 4.98 \\
\hline Am-241 & $6.0 \mathrm{E}+12$ & 2.34 & $2.7 \mathrm{E}+07$ & \\
\hline Cm-244 & $6.9 \mathrm{E}+03$ & 2.91 & Negligible & \\
\hline Total & $2.7 \mathrm{E}+16$ & & $1.7 \mathrm{E}+14$ & \\
\hline
\end{tabular}

Three new inventories were estimated for the optimization study, the 92-ac LLWMU shallow land burial (SLB), the post-1988 92-ac LLWMU SLB, and the Northern Expansion Area inventories (Tables A1.5 and A1.6). The 92-ac LLWMU SLB waste volume and inventory is calculated as the sum of the pre-1988 and post-1988 SLB inventories less the FY 2008 Northern Expansion Area SLB inventory. The post-1988 92-ac SLB inventory can be estimated in the same fashion, integrating post-1988 disposal rates only. The Northern Expansion Area disposal rates were developed from a database query retrieving records for P08U, P10C, P12C, P14U, P15U, P16C, P16U, and the SLB portion of P13U.

Table A1.5 Geometric mean and standard deviation of 500 LHS realizations of the 92-ac LLWMU and the FY 2008 Northern Expansion Area SLB inventories on October 1, 2028.

\begin{tabular}{|c|c|c|c|c|}
\hline \multirow[b]{2}{*}{ Nuclide } & \multicolumn{2}{|c|}{ 92-ac LLWMU SLB Inventory } & \multicolumn{2}{|c|}{$\begin{array}{c}\text { FY } 2008 \text { Northern Expansion Area } \\
\text { SLB Inventory }\end{array}$} \\
\hline & $\begin{array}{l}\text { Geometric Mean } \\
(\mathrm{Bq})\end{array}$ & $\begin{array}{l}\text { Geometric } \\
\text { Standard } \\
\text { Deviation }\end{array}$ & $\begin{array}{l}\text { Geometric Mean } \\
(\mathrm{Bq})\end{array}$ & $\begin{array}{c}\text { Geometric } \\
\text { Standard Deviation }\end{array}$ \\
\hline $\mathrm{H}-3$ & $6.1 \mathrm{E}+16$ & 1.62 & $6.0 \mathrm{E}+15$ & 1.86 \\
\hline $\mathrm{C}-14$ & $5.6 \mathrm{E}+11$ & 1.66 & $6.6 \mathrm{E}+11$ & 2.03 \\
\hline Al-26 & $8.2 E+06$ & 2.07 & $0.0 \mathrm{E}+00$ & 1.01 \\
\hline $\mathrm{Cl}-36$ & $4.7 \mathrm{E}+10$ & 2.05 & $3.8 \mathrm{E}+06$ & 2.64 \\
\hline Ar-39 & $2.1 \mathrm{E}+11$ & 2.08 & $0.0 \mathrm{E}+00$ & 1.01 \\
\hline $\mathrm{K}-40$ & $2.2 \mathrm{E}+10$ & 1.69 & $4.3 \mathrm{E}+09$ & 2.04 \\
\hline Ca-41 & $3.3 \mathrm{E}+11$ & 2.07 & Negligible & 1.01 \\
\hline Co-60 & $2.2 E+12$ & 2.55 & $1.8 E+14$ & 2.20 \\
\hline
\end{tabular}




\begin{tabular}{|c|c|c|c|c|}
\hline \multirow[b]{2}{*}{ Nuclide } & \multicolumn{2}{|c|}{ 92-ac LLWMU SLB Inventory } & \multicolumn{2}{|c|}{$\begin{array}{c}\text { FY } 2008 \text { Northern Expansion Area } \\
\text { SLB Inventory }\end{array}$} \\
\hline & $\begin{array}{l}\text { Geometric Mean } \\
(\mathrm{Bq})\end{array}$ & $\begin{array}{l}\text { Geometric } \\
\text { Standard } \\
\text { Deviation }\end{array}$ & $\begin{array}{l}\text { Geometric Mean } \\
(\mathrm{Bq})\end{array}$ & $\begin{array}{c}\text { Geometric } \\
\text { Standard Deviation }\end{array}$ \\
\hline $\mathrm{Ni}-59$ & $2.6 \mathrm{E}+10$ & 2.02 & $8.3 E+11$ & 2.10 \\
\hline $\mathrm{Ni}-63$ & $2.7 \mathrm{E}+12$ & 2.03 & $6.4 \mathrm{E}+13$ & 2.15 \\
\hline Se-79 & $5.8 \mathrm{E}+11$ & 2.47 & $2.6 \mathrm{E}+12$ & 2.22 \\
\hline $\mathrm{Kr}-85$ & $4.1 \mathrm{E}+11$ & 2.85 & $2.6 \mathrm{E}+09$ & 2.48 \\
\hline Sr-90 & $4.2 E+15$ & 2.41 & $1.2 \mathrm{E}+16$ & 2.64 \\
\hline Zr-93 & $1.3 \mathrm{E}+09$ & 1.94 & $1.5 \mathrm{E}+05$ & 2.70 \\
\hline $\mathrm{Nb}-93 \mathrm{~m}$ & $1.1 \mathrm{E}+11$ & 2.07 & $9.6 \mathrm{E}+04$ & 2.70 \\
\hline $\mathrm{Nb}-94$ & $2.8 \mathrm{E}+11$ & 2.12 & $1.6 \mathrm{E}+11$ & 2.70 \\
\hline Tc-99 & $5.2 \mathrm{E}+13$ & 1.98 & $3.1 \mathrm{E}+14$ & 1.91 \\
\hline $\mathrm{Pd}-107$ & $5.2 \mathrm{E}+07$ & 2.00 & Negligible & 1.01 \\
\hline $\mathrm{Ag}-108 \mathrm{~m}$ & $2.5 \mathrm{E}+11$ & 2.54 & $5.6 \mathrm{E}+05$ & 2.33 \\
\hline Cd-113m & $1.4 \mathrm{E}+11$ & 1.92 & $1.6 \mathrm{E}+05$ & 2.61 \\
\hline Sn-121m & $2.5 \mathrm{E}+12$ & 2.08 & Negligible & 1.01 \\
\hline Sn-126 & $7.0 \mathrm{E}+09$ & 2.28 & $2.9 \mathrm{E}+10$ & 2.08 \\
\hline $\mathrm{I}-129$ & $1.5 \mathrm{E}+09$ & 1.72 & $1.5 \mathrm{E}+09$ & 1.98 \\
\hline Ba-133 & $1.3 \mathrm{E}+09$ & 2.21 & $3.8 \mathrm{E}+07$ & 2.61 \\
\hline Cs-135 & $9.5 \mathrm{E}+08$ & 1.96 & $4.5 \mathrm{E}+04$ & 2.65 \\
\hline Cs-137 & $4.2 \mathrm{E}+15$ & 2.92 & $5.2 \mathrm{E}+13$ & 1.87 \\
\hline Pm-145 & $6.9 \mathrm{E}+04$ & 2.67 & $3.6 \mathrm{E}+02$ & 2.67 \\
\hline Pm-146 & $1.4 \mathrm{E}+05$ & 1.88 & Negligible & 1.01 \\
\hline Sm-151 & $1.1 \mathrm{E}+12$ & 2.00 & $2.4 \mathrm{E}+07$ & 2.07 \\
\hline Eu-150 & $3.8 \mathrm{E}+11$ & 2.19 & Negligible & 1.01 \\
\hline Eu-152 & $5.3 \mathrm{E}+12$ & 2.06 & $4.0 \mathrm{E}+13$ & 2.30 \\
\hline Eu-154 & $5.9 \mathrm{E}+11$ & 2.04 & $3.4 \mathrm{E}+13$ & 2.13 \\
\hline Gd-148 & $5.7 \mathrm{E}+03$ & 2.14 & $6.1 \mathrm{E}+03$ & 2.71 \\
\hline Gd-152 & $1.6 \mathrm{E}+00$ & 2.39 & $3.2 \mathrm{E}+00$ & 2.31 \\
\hline Ho-166m & $1.1 \mathrm{E}+10$ & 2.05 & Negligible & 1.01 \\
\hline $\mathrm{Bi}-207$ & $6.1 \mathrm{E}+06$ & 2.07 & $5.3 \mathrm{E}+06$ & 2.65 \\
\hline $\mathrm{Pb}-210$ & $9.4 \mathrm{E}+11$ & 3.13 & $8.1 \mathrm{E}+09$ & 1.81 \\
\hline Ra-226 & $1.2 \mathrm{E}+12$ & 3.16 & $1.6 \mathrm{E}+10$ & 1.80 \\
\hline Ra-228 & $5.0 \mathrm{E}+11$ & 1.59 & $1.9 \mathrm{E}+11$ & 1.63 \\
\hline Ac-227 & $1.5 \mathrm{E}+10$ & 1.82 & $2.3 \mathrm{E}+09$ & 1.87 \\
\hline Th-228 & $2.0 \mathrm{E}+12$ & 1.88 & $2.4 \mathrm{E}+11$ & 1.53 \\
\hline Th-229 & $5.5 \mathrm{E}+11$ & 2.08 & $1.9 \mathrm{E}+08$ & 1.98 \\
\hline Th-230 & $2.6 \mathrm{E}+11$ & 1.63 & $3.7 E+10$ & 1.63 \\
\hline Th-232 & $5.2 \mathrm{E}+11$ & 1.59 & $2.0 \mathrm{E}+11$ & 1.62 \\
\hline Pa-231 & $1.1 \mathrm{E}+10$ & 1.61 & $4.8 E+09$ & 1.85 \\
\hline
\end{tabular}




\begin{tabular}{|c|c|c|c|c|}
\hline \multirow[b]{2}{*}{ Nuclide } & \multicolumn{2}{|c|}{ 92-ac LLWMU SLB Inventory } & \multicolumn{2}{|c|}{$\begin{array}{c}\text { FY } 2008 \text { Northern Expansion Area } \\
\text { SLB Inventory }\end{array}$} \\
\hline & $\begin{array}{c}\text { Geometric Mean } \\
(\mathrm{Bq})\end{array}$ & $\begin{array}{l}\text { Geometric } \\
\text { Standard } \\
\text { Deviation }\end{array}$ & $\begin{array}{l}\text { Geometric Mean } \\
(\mathrm{Bq})\end{array}$ & $\begin{array}{c}\text { Geometric } \\
\text { Standard Deviation }\end{array}$ \\
\hline U-232 & $1.4 \mathrm{E}+12$ & 2.28 & $4.5 \mathrm{E}+10$ & 2.03 \\
\hline U-233 & $1.1 \mathrm{E}+14$ & 2.62 & $2.5 \mathrm{E}+10$ & 1.81 \\
\hline U-234 & $1.5 \mathrm{E}+14$ & 1.63 & $3.9 E+13$ & 1.68 \\
\hline U-235 & $6.2 \mathrm{E}+12$ & 1.63 & $2.0 \mathrm{E}+12$ & 1.67 \\
\hline U-236 & $2.8 \mathrm{E}+12$ & 1.88 & $1.4 \mathrm{E}+12$ & 1.72 \\
\hline $\mathrm{U}-238$ & $1.9 \mathrm{E}+14$ & 1.66 & $1.1 \mathrm{E}+14$ & 1.73 \\
\hline Np-237 & $2.9 \mathrm{E}+11$ & 1.80 & $8.5 \mathrm{E}+10$ & 1.88 \\
\hline Pu-238 & $1.0 \mathrm{E}+13$ & 1.62 & $3.1 \mathrm{E}+12$ & 1.96 \\
\hline Pu-239 & $1.9 \mathrm{E}+13$ & 1.71 & $6.9 \mathrm{E}+12$ & 1.84 \\
\hline $\mathrm{Pu}-240$ & $4.9 \mathrm{E}+12$ & 1.66 & $3.7 \mathrm{E}+12$ & 1.99 \\
\hline Pu-241 & $1.2 \mathrm{E}+13$ & 1.75 & $2.5 \mathrm{E}+13$ & 2.07 \\
\hline $\mathrm{Pu}-242$ & $4.0 \mathrm{E}+11$ & 2.71 & $4.4 \mathrm{E}+09$ & 1.80 \\
\hline Pu-244 & $4.9 E+09$ & 3.99 & $1.5 \mathrm{E}-04$ & 2.29 \\
\hline Am-241 & $6.7 \mathrm{E}+12$ & 1.64 & $5.6 \mathrm{E}+12$ & 1.75 \\
\hline Am-242m & $1.1 \mathrm{E}+09$ & 1.93 & $3.2 E+08$ & 1.95 \\
\hline Am-243 & $7.3 \mathrm{E}+09$ & 2.39 & $3.1 \mathrm{E}+10$ & 2.16 \\
\hline $\mathrm{Cm}-243$ & $4.9 E+09$ & 2.70 & $2.0 \mathrm{E}+08$ & 1.89 \\
\hline $\mathrm{Cm}-244$ & $4.1 \mathrm{E}+11$ & 1.99 & $2.3 \mathrm{E}+11$ & 2.11 \\
\hline $\mathrm{Cm}-245$ & $7.8 \mathrm{E}+10$ & 2.38 & $4.1 \mathrm{E}+11$ & 2.00 \\
\hline $\mathrm{Cm}-246$ & $1.4 \mathrm{E}+10$ & 2.54 & $6.9 \mathrm{E}+10$ & 2.16 \\
\hline $\mathrm{Cm}-247$ & $9.7 \mathrm{E}+02$ & 2.44 & $1.8 \mathrm{E}+01$ & 2.26 \\
\hline $\mathrm{Cm}-248$ & $3.6 \mathrm{E}+05$ & 2.28 & $9.5 \mathrm{E}+02$ & 2.26 \\
\hline Cf-249 & $7.7 E+07$ & 1.99 & $2.3 E+07$ & 2.57 \\
\hline Cf-250 & $2.2 \mathrm{E}+05$ & 2.85 & $1.0 \mathrm{E}+05$ & 2.74 \\
\hline Cf-251 & $4.5 \mathrm{E}+07$ & 2.51 & $1.8 \mathrm{E}+07$ & 2.30 \\
\hline Total & $7.0 \mathrm{E}+16$ & & $1.9 E+16$ & \\
\hline
\end{tabular}


Table A1.6 Geometric mean and standard deviation of 500 LHS realizations of the post-1988 92-ac LLWMU SLB inventory on October 1, 2028

\begin{tabular}{|c|c|c|c|c|c|}
\hline Nuclide & $\begin{array}{c}\text { Geometric Mean } \\
(\mathrm{Bq})\end{array}$ & $\begin{array}{l}\text { Geometric } \\
\text { Standard } \\
\text { Deviation }\end{array}$ & Nuclide & $\begin{array}{c}\text { Geometric Mean } \\
(\mathrm{Bq})\end{array}$ & $\begin{array}{l}\text { Geometric } \\
\text { Standard } \\
\text { Deviation }\end{array}$ \\
\hline $\mathrm{H}-3$ & $2.3 E+16$ & 1.85 & Ho-166m & $4.1 \mathrm{E}+07$ & 2.77 \\
\hline C-14 & $2.4 \mathrm{E}+11$ & 1.82 & $\mathrm{Bi}-207$ & $5.0 \mathrm{E}+06$ & 2.16 \\
\hline Al-26 & $3.0 \mathrm{E}+04$ & 2.95 & $\mathrm{~Pb}-210$ & $4.4 \mathrm{E}+10$ & 1.57 \\
\hline $\mathrm{Cl}-36$ & $1.8 \mathrm{E}+08$ & 2.66 & Ra-226 & $5.3 E+10$ & 1.63 \\
\hline Ar-39 & $7.9 \mathrm{E}+08$ & 2.75 & Ra-228 & $4.3 \mathrm{E}+11$ & 1.67 \\
\hline Ar-42 & $0.0 \mathrm{E}+00$ & 1.01 & Ac-227 & $2.5 \mathrm{E}+09$ & 1.48 \\
\hline $\mathrm{K}-40$ & $7.7 \mathrm{E}+09$ & 1.76 & Th-228 & $1.9 \mathrm{E}+12$ & 1.94 \\
\hline $\mathrm{Ca}-41$ & $1.2 \mathrm{E}+09$ & 2.67 & Th-229 & $5.5 \mathrm{E}+11$ & 2.09 \\
\hline Co-60 & $1.8 \mathrm{E}+11$ & 1.84 & Th-230 & $2.1 \mathrm{E}+11$ & 1.75 \\
\hline $\mathrm{Ni}-59$ & $1.3 \mathrm{E}+10$ & 2.75 & Th-232 & $4.4 \mathrm{E}+11$ & 1.67 \\
\hline $\mathrm{Ni}-63$ & $1.8 \mathrm{E}+12$ & 2.44 & $\mathrm{~Pa}-231$ & $3.3 E+09$ & 1.54 \\
\hline Se-79 & $5.8 \mathrm{E}+11$ & 2.47 & U-232 & $1.3 \mathrm{E}+12$ & 2.31 \\
\hline $\mathrm{Kr}-85$ & $1.3 \mathrm{E}+09$ & 2.08 & U-233 & $1.1 \mathrm{E}+14$ & 2.62 \\
\hline Sr-90 & $1.6 \mathrm{E}+15$ & 2.68 & U-234 & $5.4 \mathrm{E}+13$ & 1.48 \\
\hline Zr-93 & $7.1 \mathrm{E}+07$ & 2.18 & U-235 & $2.4 \mathrm{E}+12$ & 1.47 \\
\hline $\mathrm{Nb}-93 \mathrm{~m}$ & $8.9 E+08$ & 2.62 & U-236 & $1.4 \mathrm{E}+12$ & 1.63 \\
\hline $\mathrm{Nb}-94$ & $1.2 \mathrm{E}+09$ & 2.37 & U-238 & $8.3 E+13$ & 1.49 \\
\hline Tc-99 & $3.4 \mathrm{E}+13$ & 2.16 & Np-237 & $4.8 \mathrm{E}+10$ & 1.60 \\
\hline $\mathrm{Pd}-107$ & $7.1 \mathrm{E}+05$ & 1.97 & $\mathrm{Pu}-238$ & $3.1 \mathrm{E}+12$ & 1.53 \\
\hline $\mathrm{Ag}-108 \mathrm{~m}$ & $2.5 \mathrm{E}+11$ & 2.54 & Pu-239 & $4.6 \mathrm{E}+12$ & 1.50 \\
\hline $\mathrm{Cd}-113 \mathrm{~m}$ & $2.8 \mathrm{E}+10$ & 2.50 & Pu-240 & 1.6E+12 & 1.67 \\
\hline $\mathrm{Sn}-121 \mathrm{~m}$ & $1.1 \mathrm{E}+10$ & 2.74 & Pu-241 & 7.2E+12 & 1.97 \\
\hline Sn-126 & $6.2 \mathrm{E}+09$ & 2.46 & Pu-242 & $4.0 \mathrm{E}+11$ & 2.72 \\
\hline $\mathrm{I}-129$ & $1.4 \mathrm{E}+09$ & 1.75 & Pu-244 & $4.0 \mathrm{E}+04$ & 2.53 \\
\hline Ba-133 & $1.0 \mathrm{E}+09$ & 2.32 & Am-241 & $2.1 \mathrm{E}+12$ & 1.60 \\
\hline Cs-135 & $3.2 \mathrm{E}+07$ & 2.16 & $\mathrm{Am}-242 \mathrm{~m}$ & $1.1 \mathrm{E}+09$ & 1.93 \\
\hline Cs-137 & $6.7 \mathrm{E}+14$ & 2.38 & Am-243 & $6.5 \mathrm{E}+09$ & 2.56 \\
\hline Pm-145 & $6.9 \mathrm{E}+04$ & 2.67 & $\mathrm{Cm}-243$ & $1.2 \mathrm{E}+08$ & 2.12 \\
\hline $\mathrm{Pm}-146$ & $1.4 \mathrm{E}+05$ & 1.88 & $\mathrm{Cm}-244$ & $2.7 E+11$ & 2.09 \\
\hline Sm-146 & $6.5 \mathrm{E}-02$ & 1.76 & $\mathrm{Cm}-245$ & $7.8 \mathrm{E}+10$ & 2.38 \\
\hline Sm-151 & $1.8 \mathrm{E}+10$ & 1.98 & $\mathrm{Cm}-246$ & $1.4 \mathrm{E}+10$ & 2.54 \\
\hline Eu-150 & 1.6E+09 & 3.36 & $\mathrm{Cm}-247$ & $9.7 \mathrm{E}+02$ & 2.44 \\
\hline Eu-152 & $2.1 \mathrm{E}+12$ & 2.52 & $\mathrm{Cm}-248$ & $2.4 \mathrm{E}+05$ & 2.64 \\
\hline Eu-154 & $1.9 \mathrm{E}+11$ & 2.65 & Cf-249 & 7.7E+07 & 1.99 \\
\hline Gd-148 & $5.7 \mathrm{E}+03$ & 2.14 & Cf-251 & $4.5 \mathrm{E}+07$ & 2.51 \\
\hline Gd-152 & 1.6E-01 & 2.49 & Total & $2.6 \mathrm{E}+16$ & \\
\hline
\end{tabular}


The waste volume estimated for each inventory is summarized in Table A1.7.

Table A1.7 Disposed inventory waste volumes

\begin{tabular}{|c|c|}
\hline Inventory & Waste Volume $\mathbf{( m}^{\mathbf{3}} \mathbf{)}$ \\
\hline Post-1988 92-ac LLWMU SLB & $1.8 \mathrm{E} 5$ \\
\hline 92-ac LLWMU SLB & $3.5 \mathrm{E} 5$ \\
\hline Northern Expansion Area SLB & $1.6 \mathrm{E} 5$ \\
\hline Future SLB & $2.0 \mathrm{E} 5$ \\
\hline Pit 6 RaDU Upper Cell & $9.2 \mathrm{E} 3$ \\
\hline Pit 6 RaDU Lower Cell & $5.0 \mathrm{E} 3$ \\
\hline Pit 13 RaDU & $1.1 \mathrm{E} 4$ \\
\hline Pre-1988 Area 5 RWMS & $1.7 \mathrm{E} 5$ \\
\hline Post-1988 Area 5 RWMS & $3.4 \mathrm{E} 5$ \\
\hline Pre-1988 GCD & $2.7 \mathrm{E} 2$ \\
\hline Post-1988 GCD & 14 \\
\hline
\end{tabular}




\section{A2 Sensitivity Analysis of Total Closure Cost}

The sensitivity analysis of total closure cost is complicated by numerous model inputs and a model structure that includes stochastic settlement events. Model parameters affecting the collective dose (the number of residents, location of residents, etc.) are changing over the course of a simulation. Identifying relationships between these time varying parameters and the final collective dose is problematic.

The model output evaluated is the total closure cost for a 2.5 -meter $(\mathrm{m})(8.2$-foot [ $\mathrm{ft}])$ cover for the three disposal configurations: the 92-ac LLWMU, the Northern Expansion Area, and the total Area 5 RWMS. The approach is to fit a generalized boosted model (gbm) to the data. The parameters selected for the model are based on an understanding of the GoldSim model structure. The total closure cost is calculated as the sum of two intermediate results: the cover construction cost and the collective dose cost. The total closure cost is known to be nearly equal to the construction cost. Examination of the construction cost model indicates that six stochastic input parameters contribute to the uncertainty in this calculated result. Therefore, a gbm was fit using seven independent parameters: the collective dose cost and the six stochastic inputs to cover construction costs.

\section{A2.1 Model Fitting}

A gbm of total closure cost was fit using the cost of collective dose and the six stochastic input parameters contributing to construction costs as the independent variables. The six stochastic inputs to construction cost are the Environmental Management indirect rate, infrastructure indirect rate, construction indirect rate, fixed fee rate, contingency, and the escalation rate. A $\mathrm{gbm}$ is a nonparametric regression method based on the methods of Friedman $(2001 ; 2002)$. The R gbm package was used for the model fitting (Ridgeway, 2007; R Development, 2008). The package returns the gbm model, a plot of the marginal dependence, and the relative influence for each parameter. The marginal dependence plot displays the model response over the range of the input parameters with all other input parameters integrated out of the model. The relative influence is the percent reduction in the model mean square error obtained by adding the variable to the model. The relative influence is used as a measure of sensitivity, with zero indicating no sensitivity and 100 indicating maximum sensitivity. The relative influence estimates the percentage of the model prediction variance that is explained by the parameter.

The seven model parameters in the gbm explain a majority of the total closure cost variance. The only intermediate result, collective dose cost, is a minor source of variance. Model fitting was stopped at these seven parameters because nearly all variance in the total closure cost was explained by the stochastic input parameters in the model.

\section{A2.2 Results}

Good fits were obtained for the gbm, with the best fits observed for the Northern Expansion Area and the Area 5 RWMS (Figures A2.1-A2.3). The slightly poorer fit for the 92-ac LLWMU is due to a single outlier with a high collective dose. 


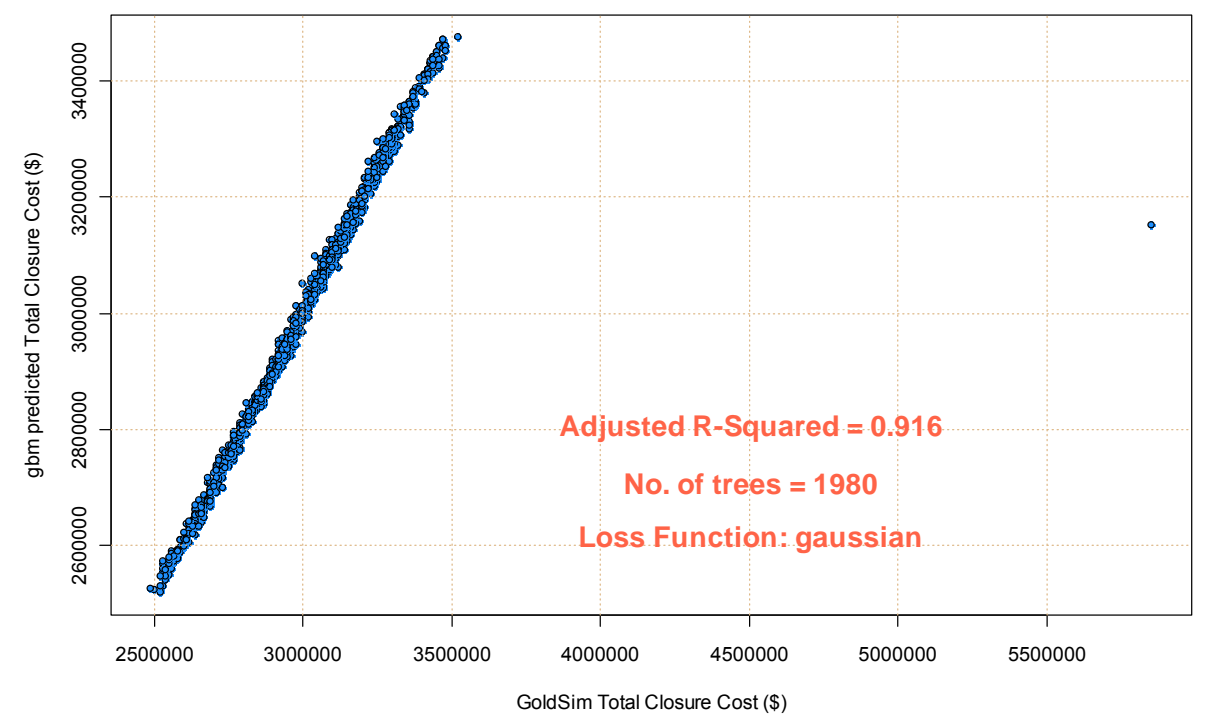

Figure A2.1 GBM predicted total closure costs versus GoldSim model result for the 92-ac LLWMU with a 2.5-m closure cover

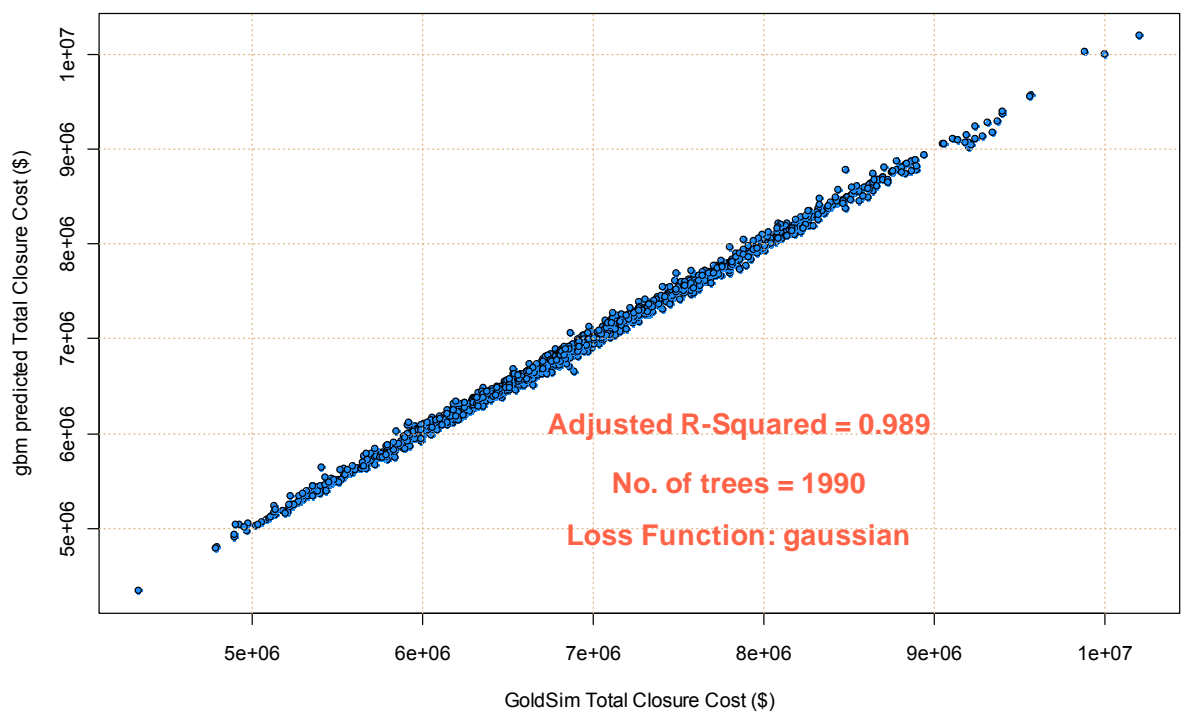

Figure A2.2 GBM predicted total closure costs versus GoldSim model result for the Northern Expansion Area with a 2.5-m closure cover 


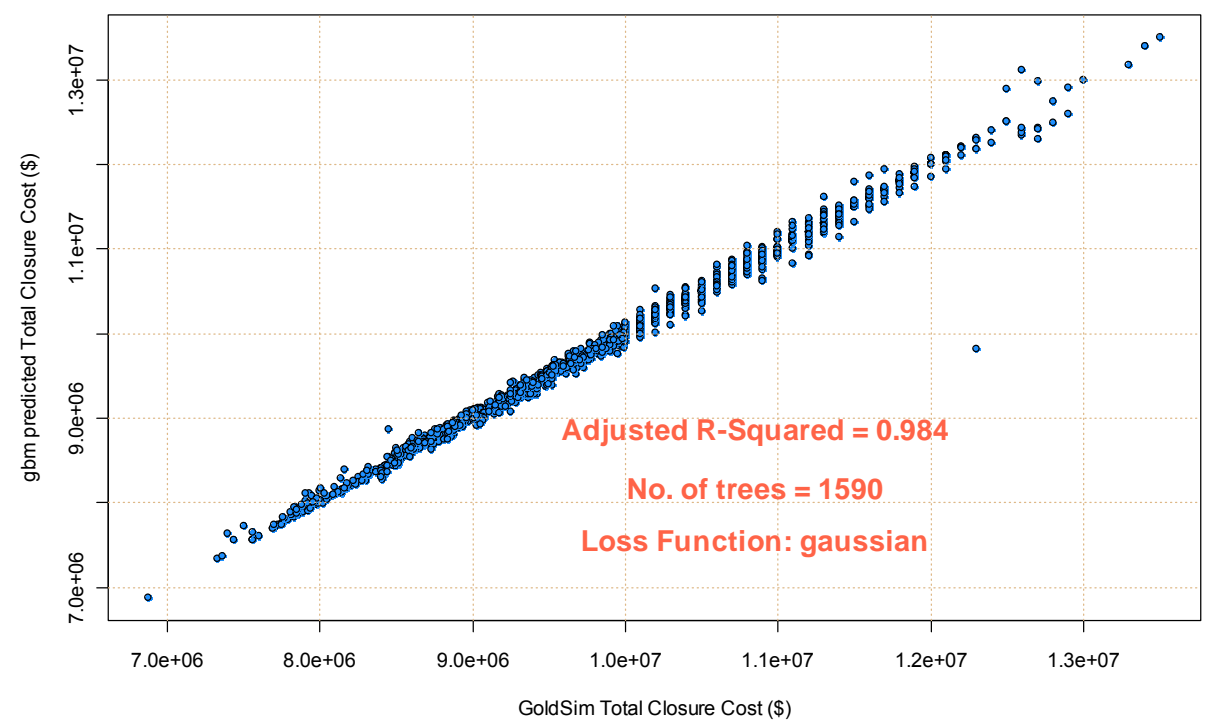

Figure A2.3 GBM predicted total closure costs versus GoldSim model result for the total Area 5 RWMS with a 2.5-m closure cover

The gbm predicted total closure cost is most sensitive to parameters used to calculate the cover construction cost. There is a generally linearly increasing relationship between the most sensitive parameters, the contingency and future cost escalation rate, and the total closure cost. Contingency represents the uncertainty of the cost estimator.

The 92-ac LLWMU total closure cost is most sensitive to the contingency with 89.8 percent of the model variance explained by this factor (Figure A2.4). For the Northern Expansion Area, which is assumed to be closed in 2028, the cost escalation rate becomes the most important, explaining 61.3 percent of the model variance (Figure A2.5). The variance explained by the contingency and the escalation rate are approximately equal for the closure of the total Area 5 RWMS (Figure A2.6). Uncertainty in near-term closure costs are contributed mostly by the estimator's uncertainty. As the time to closure increases, uncertainty contributed by the escalation rate of costs begins to dominate. In all cases uncertainty contributed by the cost of the collective dose is negligible. 

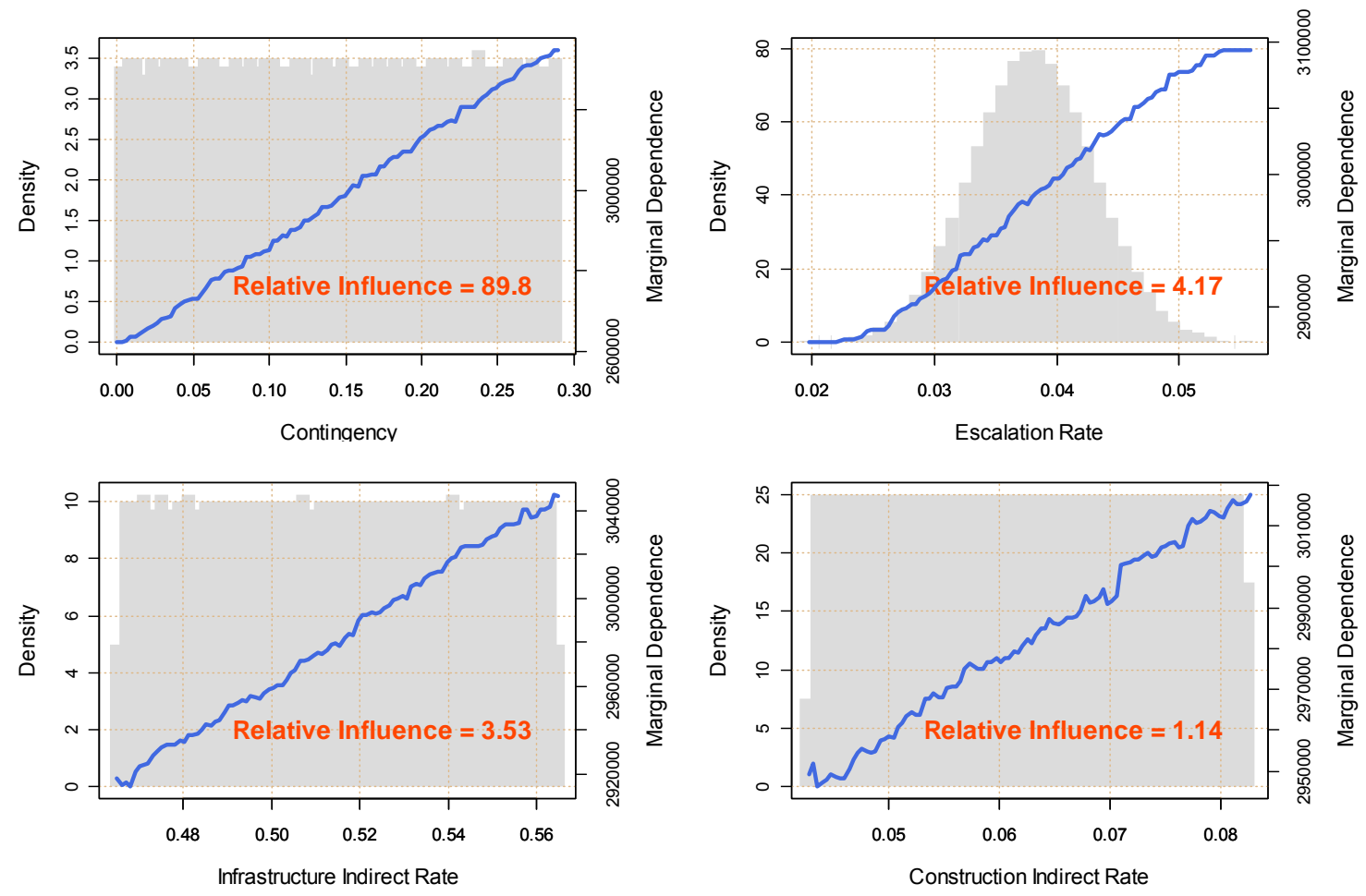

Figure A2.4 Density histogram (gray) and marginal dependence (blue) of the most sensitive parameters for the total closure cost for closure of the 92-ac LLWMU with a 2.5-m cover
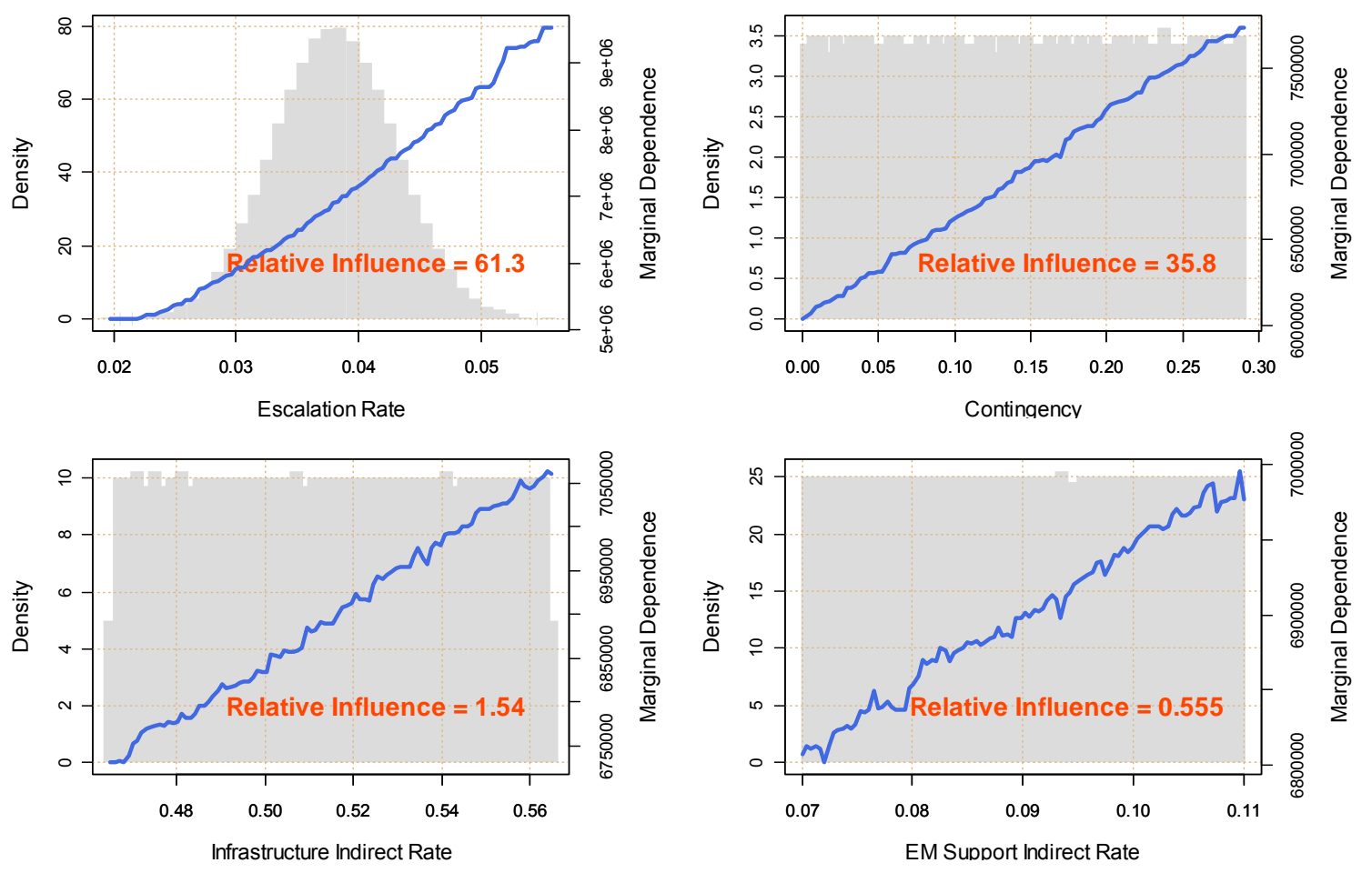

Figure A2.5 Density histogram (gray) and marginal dependence (blue) of the most sensitive parameters for the total closure cost for closure of the Northern Expansion Area with a 2.5-m cover 

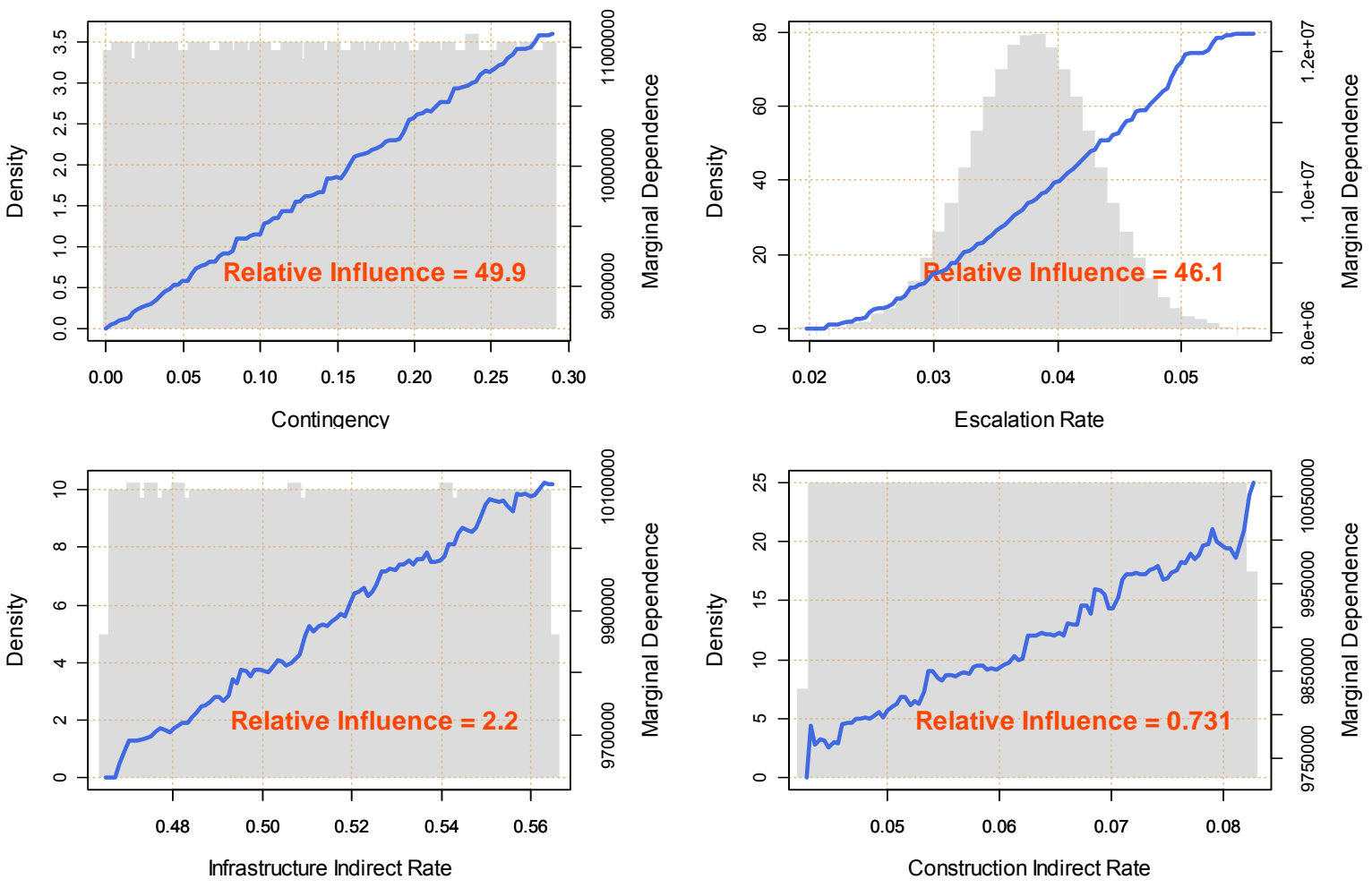

Figure A2.6 Density histogram (gray) and marginal dependence (blue) of the most sensitive parameters for the total closure cost for closure of the total Area 5 RWMS with a 2.5-m cover

\section{A2.3 References}

Friedman, J., 2001. Greedy Function Approximation: A Gradient Boosting Machine. The Annals of Statistics 29: 1189-1232.

Friedman, J., 2002. Stochastic Gradient Boosting. Computational Statistics and Data Analysis 38: $367-378$.

R Development Core Team, 2008. R: A Language and Environment for Statistical Computing. $\mathrm{R}$ Foundation for Statistical Computing, Vienna, Austria: Available online at: http://www.R-project.org. Accessed January 6, 2009.

Ridgeway, G., 2007. Generalized Boosted Models: A Guide to the GBM Package. Available online at http://cran.r-project.org/web/packages/gbm/vignettes/gbm.pdf, Accessed January 6, 2009. 
This Page Intentionally Left Blank 


\section{DISTRIBUTION}

Environmental Management Library

1 digital file

National Security Technologies, LLC

P.O. Box 98521, M/S NLV094

Las Vegas, NV 89193-8521

U.S. Department of Energy

2 CDs

National Nuclear Security Administration

Nevada Site Office

Public Reading Facility

P.O. Box 98521, M/S 400

Las Vegas, NV 89193-8521

U.S. Department of Energy

$1 \mathrm{CD}$

National Nuclear Security Administration

Nevada Site Office

Technical Library

P.O. Box 98518, M/S 505

Las Vegas, NV 89193-8518

U.S. Department of Energy

Office of Scientific and Technical Information

1 digital file

P.O. Box 62

Oak Ridge, TN 37831-0062

Jhon T. Carilli

U.S. Department of Energy

4 copies

National Nuclear Security Administration

Nevada Site Office

P.O. Box 98518, M/S 505

Las Vegas, NV 89193-8518

Bruce M. Crowe

1 copy

Stoller Navarro Joint Venture/Battelle

P.O. Box 98518, M/S 505

Las Vegas, NV 89193-8518

E. Frank Di Sanza

1 copy

U.S. Department of Energy

National Nuclear Security Administration

Nevada Site Office

P.O. Box 98518, M/S 505

Las Vegas, NV 89193-8518 
David B. Hudson

1 copy

National Security Technologies, LLC

P.O. Box 98521, M/S NLV083

Las Vegas, NV 89193-8521

Susan K. Krenzien

1 copy

Navarro Research and Engineering, Inc.

P.O. Box 98518, M/S 505

Las Vegas, NV 89193-8518

Gregory J. Shott

National Security Technologies, LLC

1 copy

P.O. Box 98521, M/S NLV083

Las Vegas, NV 89193-8521

Vefa Yucel

National Security Technologies, LLC

1 copy

P.O. Box 98521, M/S NLV083

Las Vegas, NV 89193-8521 